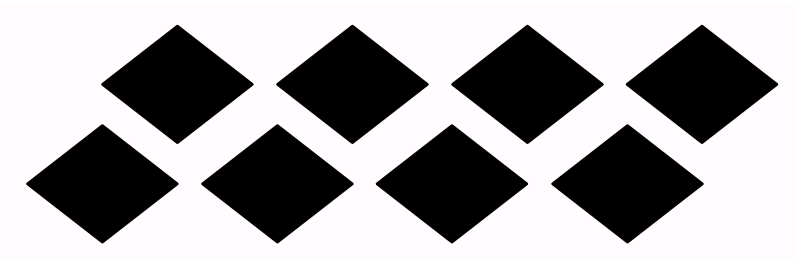

وثيقة وقف شرعية عثمانية

دراسة أثرية حضارية

د. عاطن سمد هميد

كلية الآثار بقتا 
$-\Gamma \leqslant \wedge-$ 
تتناول الدراسة نسخة طبق الأصل من وثيقة وقف الأمير فيروز أغا بن عبدالله،

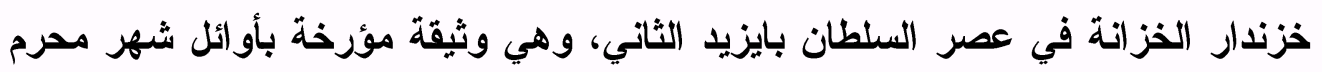

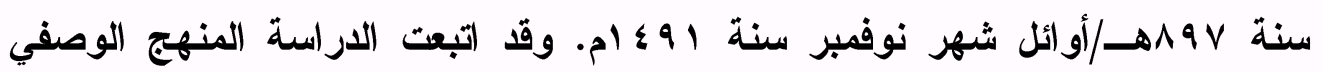
التحليلي عن طريق تناول هذه الوثيقة ودراسة شكلها من ناحية هيئتها الواردة عليها،

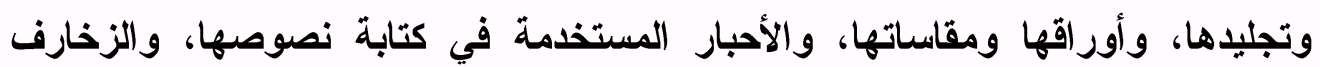

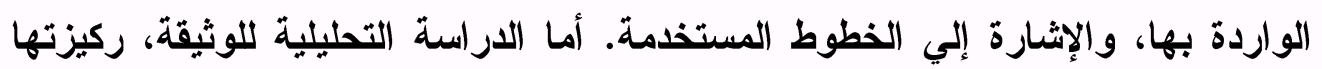

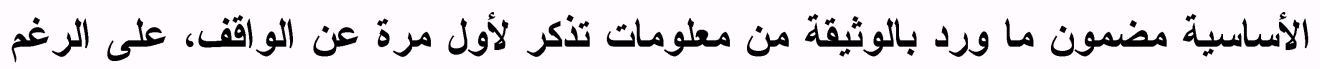
من شهرته الواسعة، وكذلك معلومات عن موقوفاته والمنشآت الخيرية، وباقي أركان

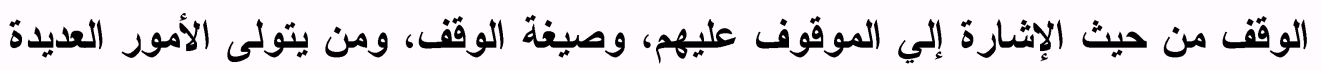

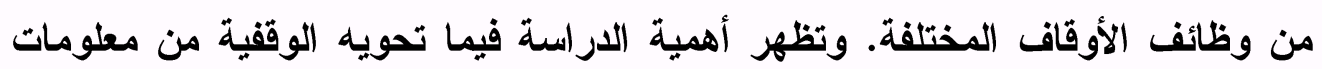
مهمة تظهر مدى التقدم العضاري الذي كانت عليه الدول الإسلامية.

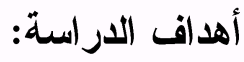

- - نشر ودراسة وتحقيق نسخة طبق الأصل من وثيقة وقف الأمير فيروز أغا.

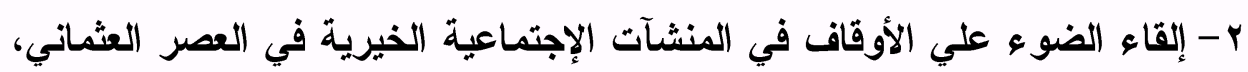
و إظهار دورها التكافلي المجتمعي.

r- التعرف علي الشروط الواجب نوافرها في الوقف، والتأكد من تحققها جميعها.

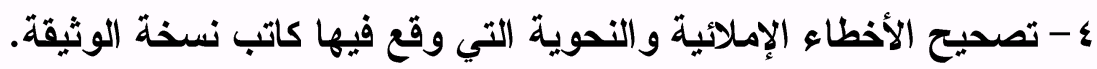

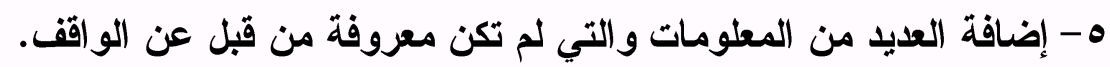

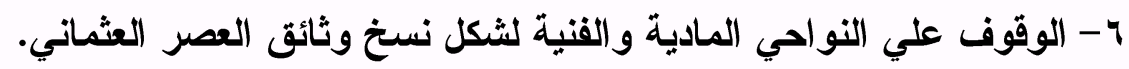

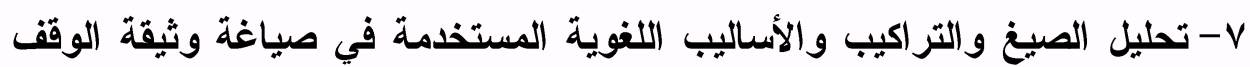
للوقوف علي استقامتها من ركاكتها، والسمات الأدبية لروح العصر.

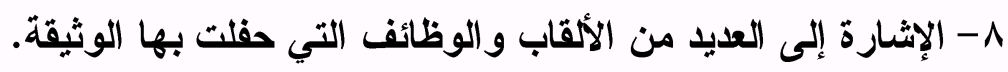

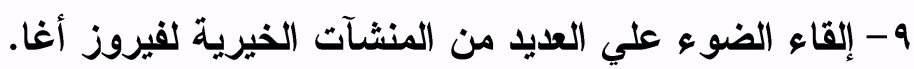
ـ ا التعريف بالعديد من القرى والمدن التركية في العصر العثماني. 


\section{منهج الاراسة:}

تتناول الاراسة نسخة طبق الأصل لوثيقة وقف الأمير فيروز أغا بن عبدالله، متبعة المنهج الوصفي التحليلي عن طريق تناول هذه الوثيقة بوصفها من ناحية شكلها وذكر بياناتها وهيئتها العامة الواردة عليها، وتجليدها، وأوراقها ومقاساتها، والأحبار المستخدمة في كتابة نصوصها، والزخارف الواردة بها، والإثارة إلي الخطوط المستخدمة.

أما عن الاراسة التحليلية لهذه النسخة، ركيزتها الأساسية مضمون ما ورد بالوثيقة، وإعمال المنهج العلمي في التحقق من صحة المعلومات والتعريف بالتراجم والأماكن والألقاب الواردة في وثيقة الوقف، وفقاً لمنهج التحقيق، وتصحيح الأخطاء الإملائية والنحوية وغيرها، التصحيح في المتن والإثارة إلى الخطأ في الهامش، وتشكيل بعض الكلمات التي تحتاج إلى ذلات ليسهل قراعتها، ووضع الههزات الناقصة والتي أغقلها الخطاط، وتصحيح الآيات القرآنية التي أخطأ في كتابتها، إضافة إلي تخريج الآيات القر آنية والأحاديث النبوية، مع تحليل مضمون ما ورد بالوثيقة من معلومات تذكر لأول مرة عن الواقف على الرغم من شهرته الواسعة، وكذلك معلومات عن موقوفاته والمنشآت الخيرية، وكذلك باقي أركان الوقف من حيث الإشارة إلي الموقوف عليهم، وصيغة الوقف، ومن يتولى الأمور العديدة من وظائف الأوقاف المختلفة. أولاً: الدراسة اسلة الوصفية للوثيقة مع تحقيقها: الوثيقة عبارة عن نسخة طبق الأصل من وثيقة وقف فيروز أغا، وموضوعها "الوقف" وأركان الوقف وهي: وقف، وواقف، وموقوف عليه، وصيغة") وقا حوث الوثيقة أركان الوقف الأربعة.

( (1) للتفاصيل عن الوقف وشروطه وصيغه و النية و العقد و غيرها يمكن الرجوع إلى : مصطفي أحمد الزرقا:

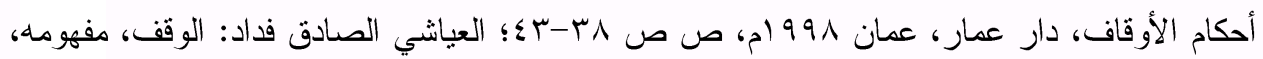
شروطه، أنو اعه، بحث بمؤتمر الأوقاف الأول جامعة أم القرى بالتعاون مع وزارة الثؤون الإسلامية

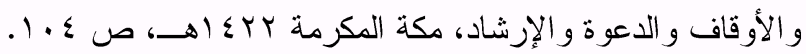




$$
\text { وبياناتها كالتالي: }
$$

مكان الحفظ: مكتبة الدولة العامة ببرلين ألمانيا. نوع الوثيقة: نسخة طبق الأصل. مضمون الوثيقة: وقف خاص.

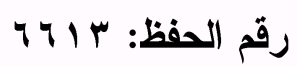

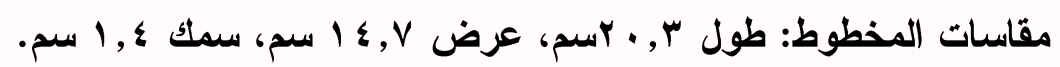
مقاسات الكتابة علي الورق: طول r,ه اسم، عرض r, بسم. المواد الخام: ورق أبيض يميل إلي الأصفرار، وحبر صيني أسود واحمر. عدد السطور: أحد عشر سطراً.

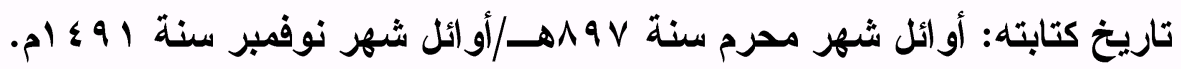
البلد أو القطر : مدينة قسطنطينية بتركيا. اللغة المستخدمة: اللغة العربية. الخط المستخدم: الخط النستعليق في نص المتن، والثلث في البسملة وبعض الكلمات. عدد أوراق المخطوط: أربع وعشرون ورقة مستخدمة. اسم الخطاط: لا يوجد.

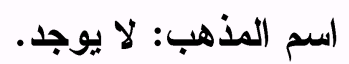
حالة المخطوط: جيدة. حالة الغلاف: جيدة. نوع الزخارف: هندسية ونباتية. اسم الو اقف: فيروز بك الو الي بلواء ولاية البوسنة، ورئيس الخزانة العامة. وصف الوثيقة: جاعت الوثيقة في شكلها العام للجلد المموه الرمادي اللون علي أرضية بيج فاتح (الغلاف) يتذذ الثكل المستطيل، فقير جذاً خال من الزخارف، لعله يتفق مع طبيعة كونه الوثيقة نسخة طبق الأصل، وليست وثيقة أصلية، لأن الغلاف لا يتناسب مع 
أهمية الوثيقة، ولم تحتو على ديباج(r)، بل حل محله جلا خفيف أصفر خال أيضاً من الزخارف، وبلسان الغلاف المتخذ الثكل المثلث، نفس التمويهات الموحودة بالغلاف كأنها إمتداد له.

ثم يلي الغلاف ديباج ثم متن الوثيقة، دون علي وجه الورقة الأولى منها نص

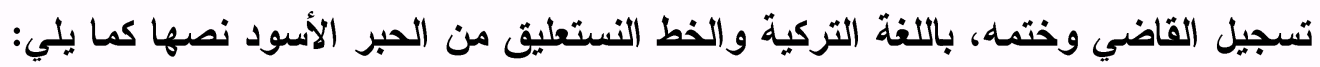

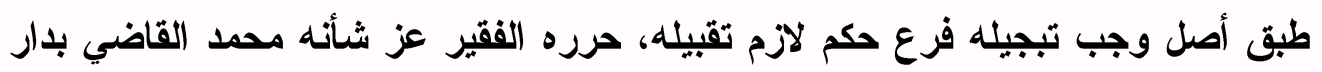

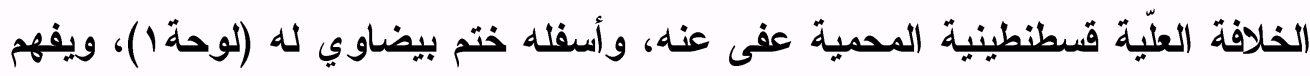
من النص أن هذه الوثيقة هي نسخة طبق الأصل، وجب إحترامها وتبجيلها، وأن العمل وله

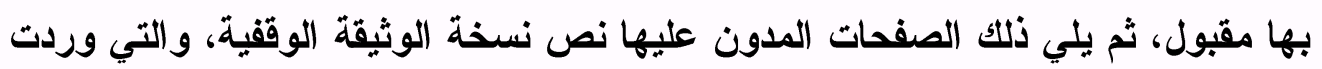
في ست وأربعين صفحة، الصفحات بداية من ظهر الورقة الأولى حتي ظهر الورقة

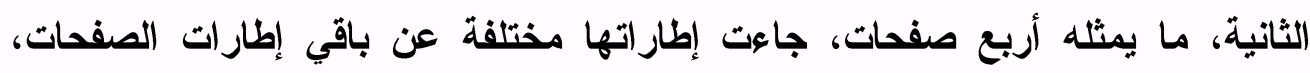

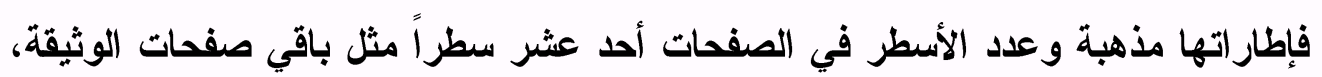
فيما عدا الصفحتين الأولى والر ابعة. عمد الفنان إلي ترك هوامش ومساحات فراغ حول النصوص، بلغت باسم من

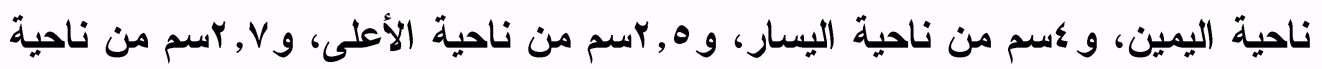

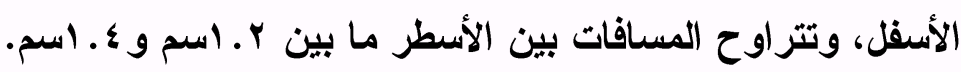

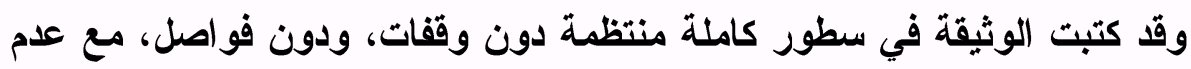
مراعاة علامات الترقيم بثكل عام، مع وجود فواصل متقطعة بين الأسطر في كل

(Y) في الو اقع أن حجة الوقف لم تحتٍِ علي الديباجة المزينة بالزخارف المعروفة بثر ائها، و التي استعاض

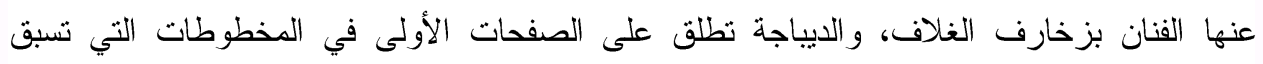
النصوص "سرلوح" وهي كلمة فارسية معناها اللوح الذي في المقدة أو الر أس، ولعله من الأفضل أن تسمي الديباجة؛ لوجود الصلة بينها وبين الديباج أو الحرير المختلف الألوان، ويطلق علي هذه وهن الصفحات أيضا غرة المخطوط.، راجع، محمد عبد العزيز مرزوق: المصحف الثريف دراسة تاريخية

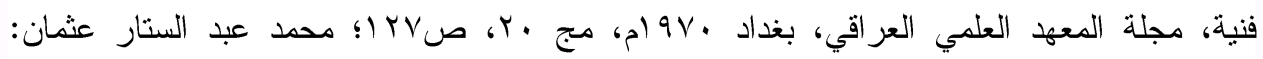

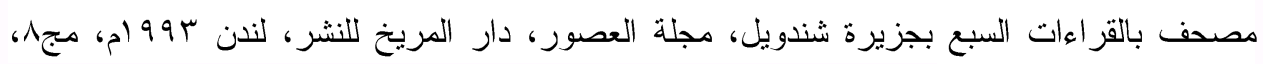

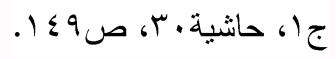


صفحاتها من الحبر الأحمر؛ ماعدا الورقتين الثانية والثالثة، مع ملاحظة عدم وضع النقط على العديد من الكلمات والحروف، ولم توضع الهمزات على الكثير من الكلمات.

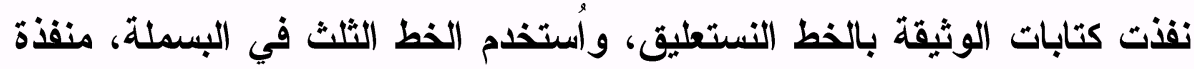

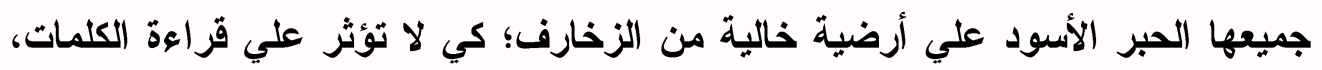
اللهم فيما عدا خطوط ونقاط تحديد من الحبر الأحمر بين السطور لتكون فاصلة، ولكي الكي تساعد الخطاط على ألا يحيد عن سطوره. وبالنسبة للنواحي المادية التي تميز النسخة، منها الخارجية: هي تللك المنعلقة

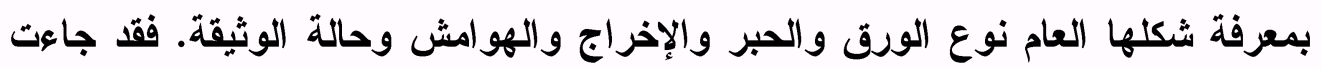

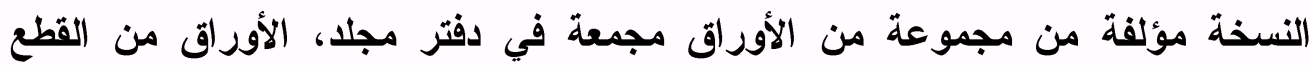

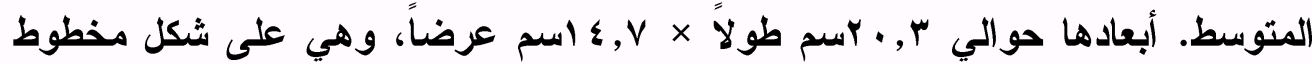

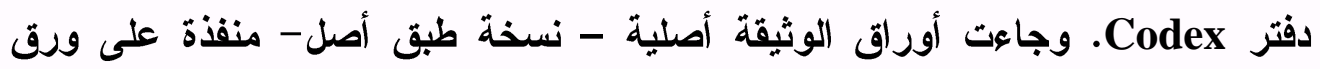
أبيض يميل إلى الاصفرار. والحبر المستعمل فيها أسود في نص المتن، وحبر أحمر في الفو (اصل.

أما الغلاف والصفحات والهوامش والسطور، في الواقع أن هذه الوثيقة مختلفة عن مثيلاتها من الوثائق التي صدرت في تركيا في العصر العثماني، حيث يلاحظ عليها أن غلافها خال تماماً من الزخارف، بما لا يتناسب وأهمية هذه الوثيقة فئة المستمدة من أهمية

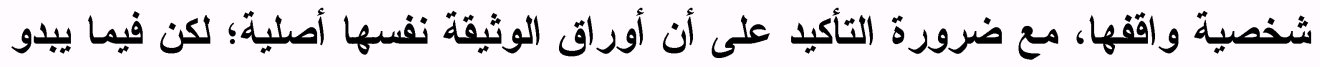
أن غلافها هذا ليس الأصلي، وربما يكون لاحقاً عليها، أما عن الصفحات فيلحظ عليها

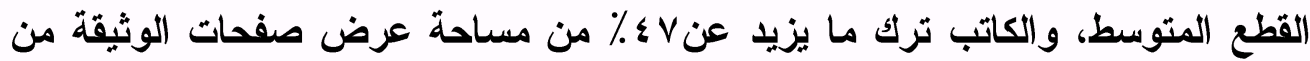

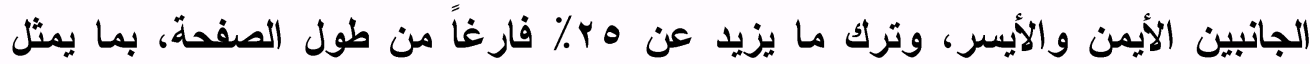

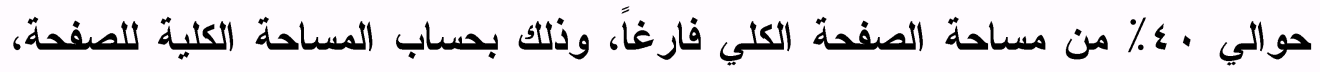

$$
\text { وخصم الجزء الفراغ منه. }
$$

أمسا عن الهوامش والسطور، فقد جاء الهامش الأيمن ضيق ساسم، والهامش

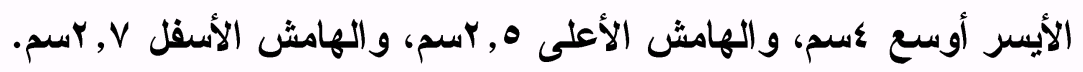

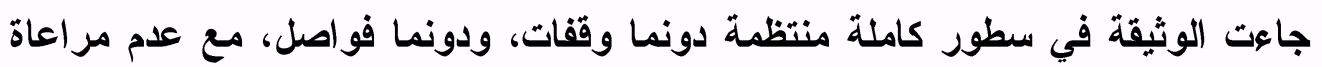

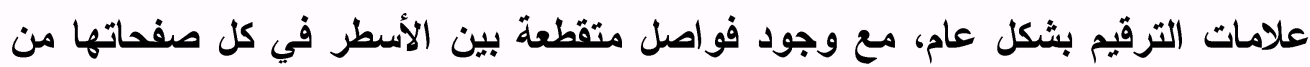


الحبر الأحمر؛ ماعدا الورقتين الثانية والثالثة، مع ملاحظة عدم وضع النقط على العديد من الكلمات والحروف، ولم توضع الهمزات على الكثير من الكلمات. نفذت كتابات الوثيقة بالخط النستعليق، واستخدم الخط الثلث في البسملة، منفذة جميعها بالحبر الأسود علي أرضية خالية من الزخارف؛ كي لا تؤثر علي قراعة الكلمات، اللهم فيما عدا خطوط ونقاط تحديد من الحبر الأحمر بين السطور لتكون فاصلة، وتساعد الخطاط كي لا يحيد عن سطوره. استخدم الكاتب اللغة العربية بسياقاتها في القرن التاسع الهجري الأي يُرى فيه قدر من التصحيف والإغتر اف، مع ملاحظة استخدام اللهجة العامية وعدم الإلتزام بقواعد التحو والإملاء مثلما وجدنا في العديد من الكلمات، والتي صححتها الاراسة في مواضعها، وتجدر الإثارة إلي أن الكاتب يستشها بالقرآن الكريم دون وضع علامات التنصيص. هذا وقد عمدت الدراسة نشر الوثيقة وقراعتها، مع الحفاظ علي ترتيب ورودها، من بدايتها حتى نهايتها، وفضلت الاراسة الحفاظ علي بداية الصفحات كما هي، كل في فقرة جديدة مع الإثارة إلي رقم الصفحة في بدايتها، ونص النسخة طبق الأصل من

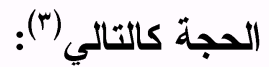
ظهر الورقة الأولى: بسم الله الرحمن الرحيم، الحمد لله الذي أنشأ(؛) المبدعات بكلمته العالية وأبدع المصنوعات(•)، بحكمته البالغة الأي خلق الإنسان من تركيب البسائط(†) والأركان، وجعله مظهراً للمعارف الإلهية وحقائق(V) الإيمان وخصه بتحمل

$$
\begin{aligned}
& \text { (r) تششر هذه الوثثقة لأول مرة، حيث لم بسبق نشر ها من قبل. }
\end{aligned}
$$

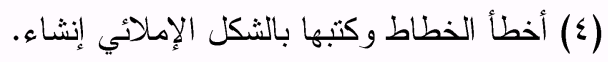

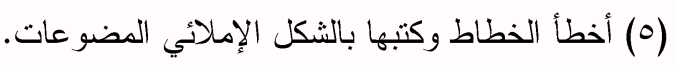

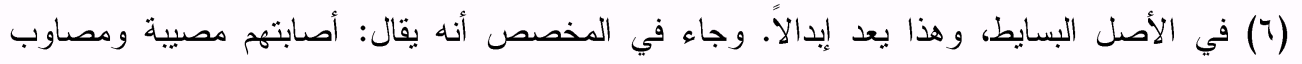

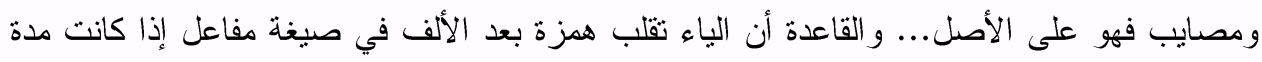
زائدة ثالثة في المفرد ولتقارب كل من (مصايب) و (مصاوب) و (مصائب) في درجة الخفة جاز لهم أن

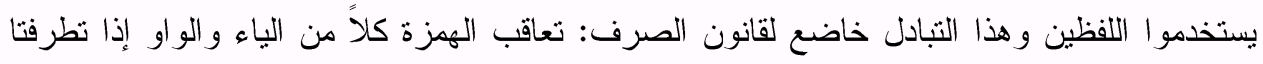
بعد ألف زائدة ككساء وسماء وبناء أصلها كساو، وسماو ، وبناي.. تعاقب الهمزة بكلاً من الباء و الواو في اسم الفاعل كقائل وبائع، قاول وبايع وهذا القلب من باب الحمل على الفعل.. تعاقب الهمزة بكلاً من الواو والياء في وزن مفاعل نحو: عجائز وصحائف أصلها عجاوز وصحايف لكون الواو والياء 
أعباء التكاليف البدنية والمالية ليفوز بإستحقاق النعيم والرضوان ووفق عباده المؤمنين

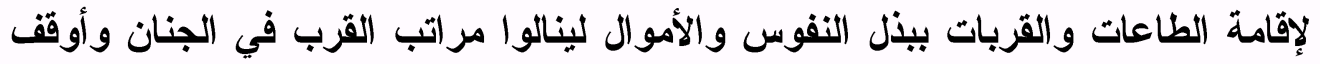
خواص المسلمين على الإعراض عمن سواه والإقبال عليه والإيثار له في السر والإعلان

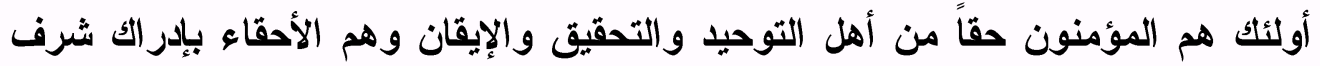
المكاشفة و المشاهدة (لوحة ب).

وجه الورقة الثانية: واللقاء الموعود لذوي السرائر والعرفان لا بإستيهال منهم

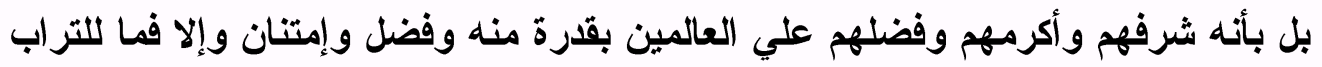
ورب الأرباب ابن الثرى وعلو رب العالم فتعالى الله المثل الحق لا إله إلا هو منه

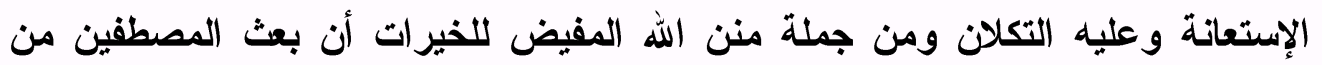

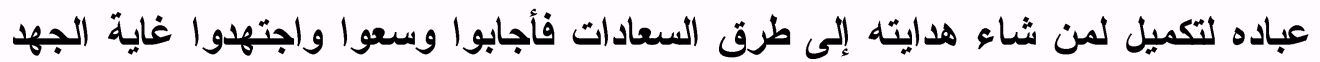
في تبليغ ما أرسلوا به من الرسالات فمن سعد سمع وقبل دعوتهم واتبع الهاءى وخالف الهوى ومن شقي ضلّ وغوى واتبع الردى وخبط خبط العشواء في ظلهات المخات الماتفات

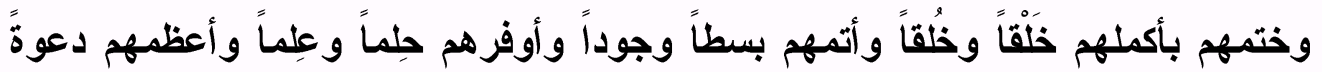

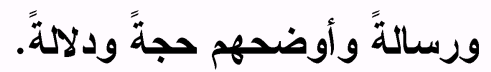

ظهر الورقة الثانية: وأقربهم منزلة وشفاعة محمد صلى الله عليه وعلى آله

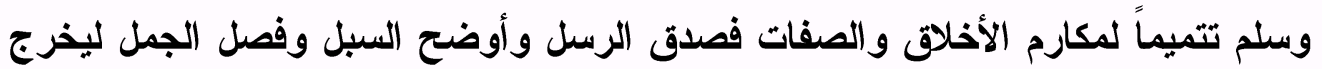
الكل من الثبه والضلالات صلى الله عليه وعليهم وعلى من صحبهم بدوام الصدق الضق

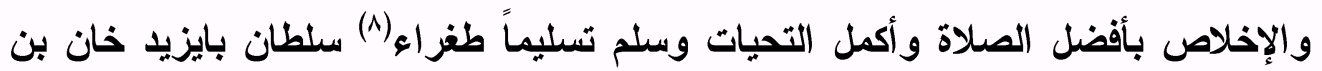

$=$

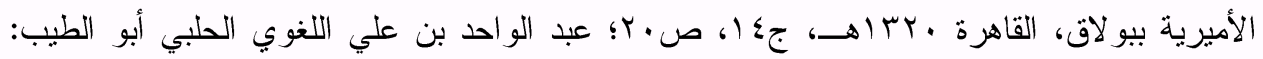

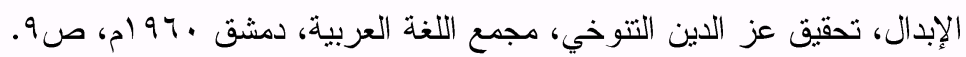

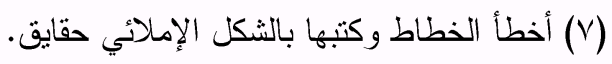

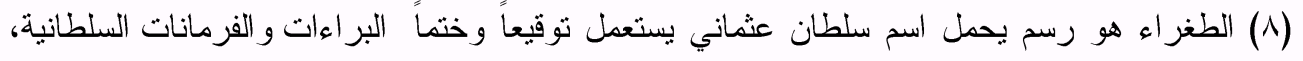

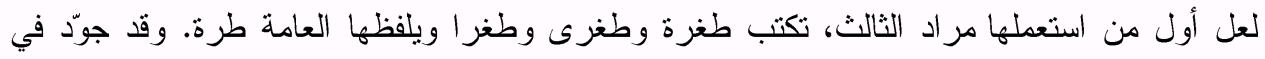

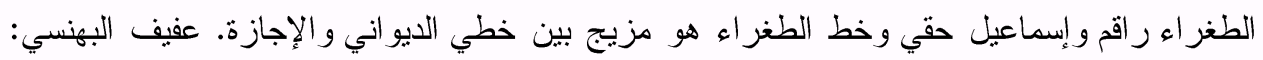

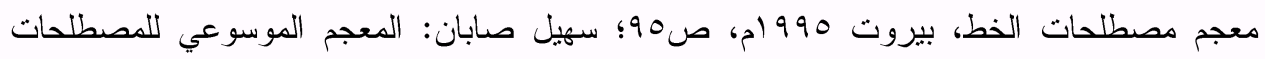

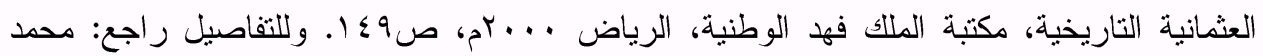
علي حامد: الطغر اء العثمانية، مخطوط ماجستير ، كلية الآثار جامعة القاهرة 914 (م. 
سلطان محمد خان (9) ايله معنون در. ما ذكر في هذا الكتاب الشرعي من أصول الوقف

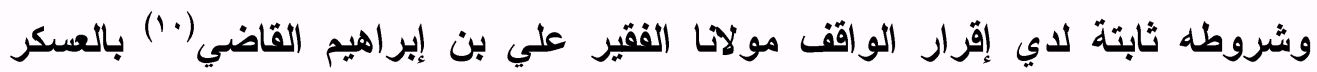

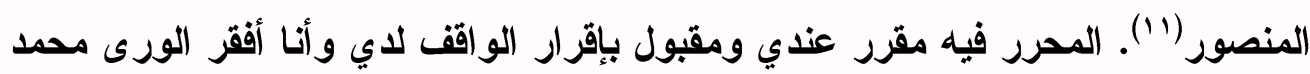

(9) السلطان بايزيد بن محمد الثاني بن مراد الثاني بن محمد الأول بن بايزيد الأول بن مراد الأول، هو

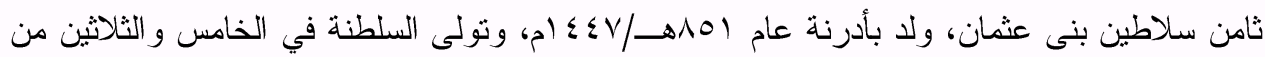
عمره، أي عام الحكم مع أخيه جم أنتهى لصالح السلطان بايزيد، وكان محباً للأدب، ومتفقهاً في علوم الشريعة الإسلامية، و عمل على مساندة مسلمي الأندلس، بعد سقوطها في أيدي الأسبان، وثرك الحكم لإبنه سليم

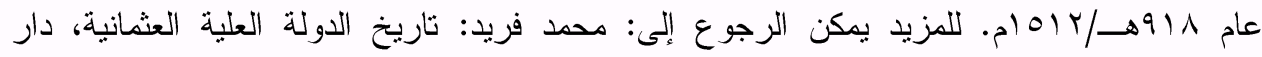

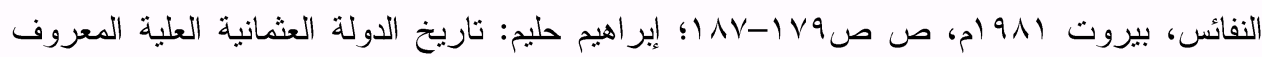

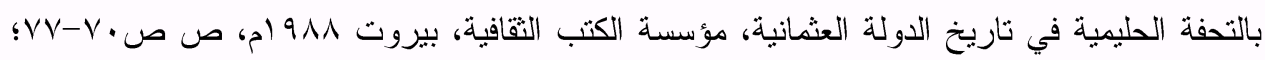

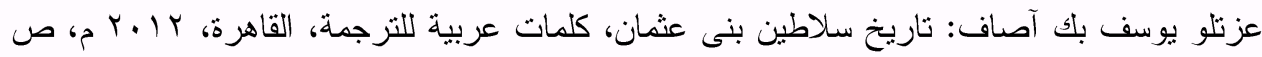
صعء-OV؛ على محمد محمد الصلابي: الدولة العثمانية عو امل النهوض و أسباب السقوط، دار الفجر

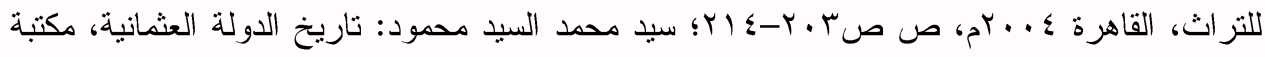

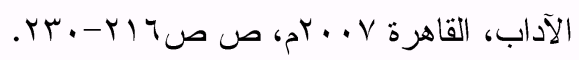

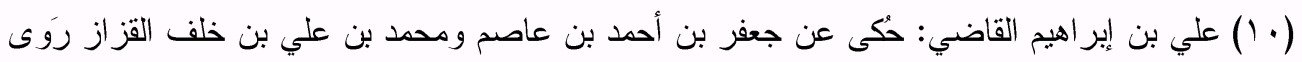
عنه أبوالحسن محمد بن علي بن الحسين الحسني العلوي الهمذاني سَمعت أبا بكر محمد بن أحمد بن بن بن بن بن

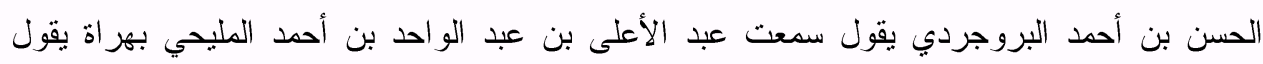
سمعت أبا محمد إسماعيل بن إبر اهيم بن محمد بن عبد الرحمن الفرات يقول سمعت الشريف أباالحسن بن بـن

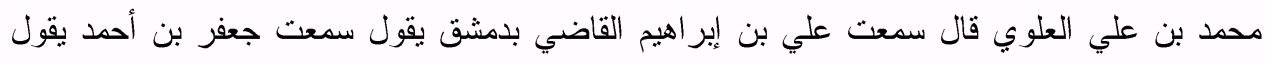
سمعت أحمد بن أبي الحواري يقول سمعت أبامسهر يقول سمعت سعيد بن عبدالعزيز يقول إذا كان الله

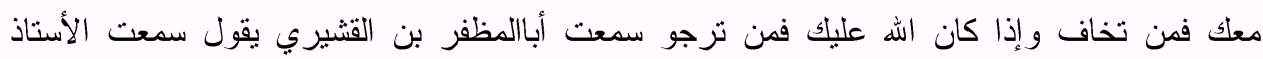

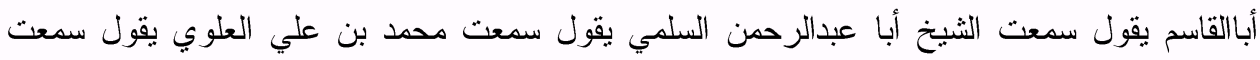
علي بن إير اهيم القاضي بدمثق يقول سمعت محمد بن علي بن جلف أبي القاسم علي بن الحسن بن

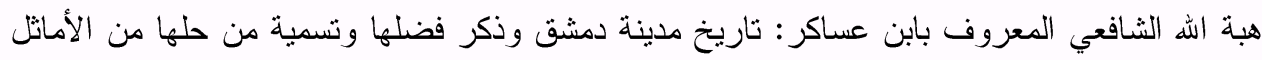
أو اجتاز بنواحيها من وارديها وأهلها، تحقيق محب الدين أبي سعيد العمروب، دار الفكر، بيروت

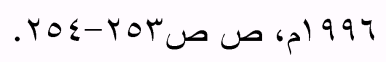

(1) صيغة تأثبرة القاضي علي يمين الصفحة. 


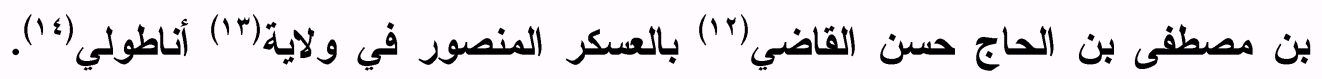

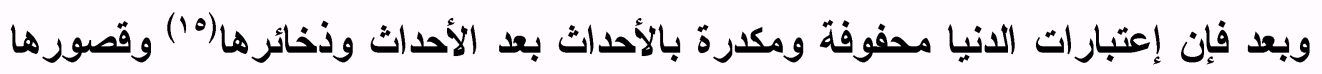

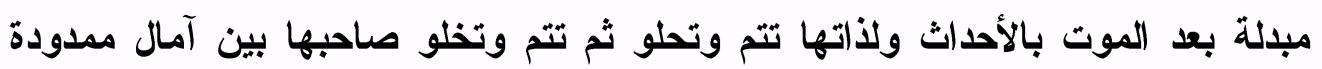

(Y Y (Y) محمد بن مصطفى بن الحاج حسن، شمس الدين الرومي، الحنفي، المعروف بحاجي حسن زاده. قال

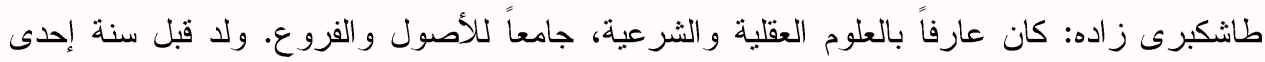

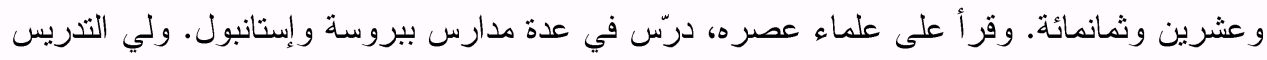

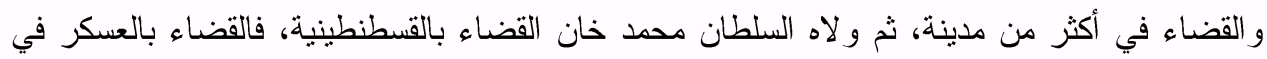

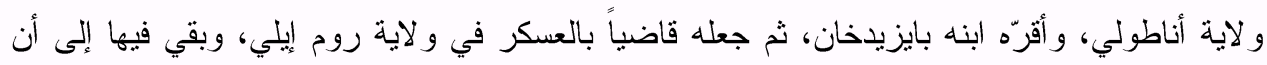

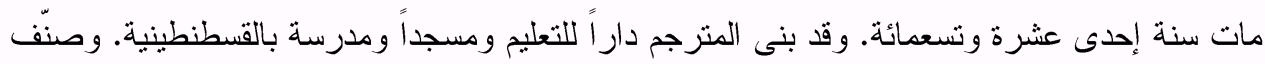

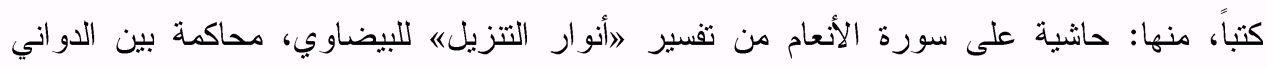

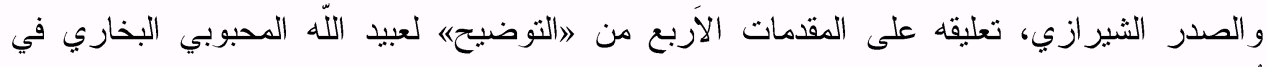

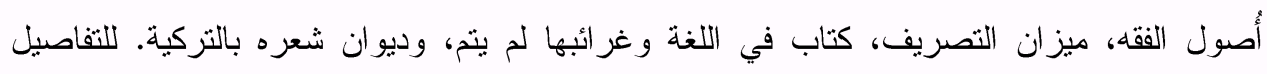

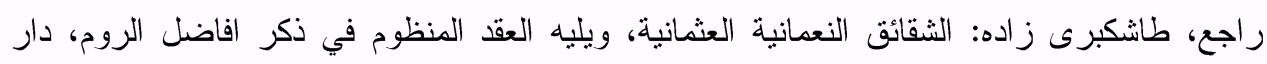

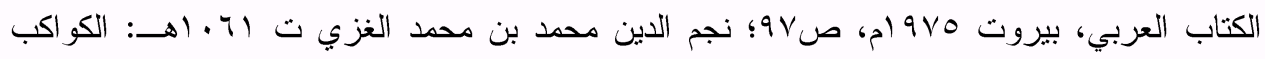

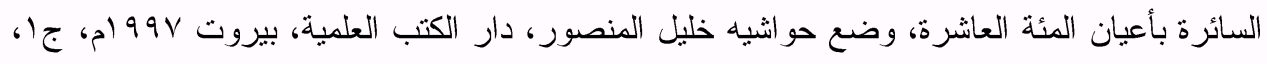

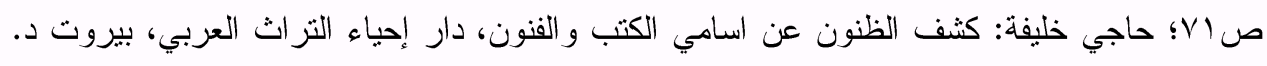

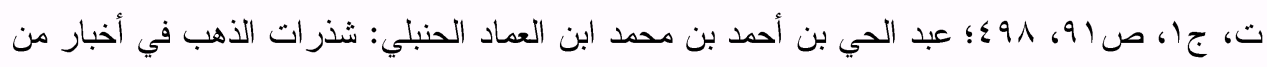

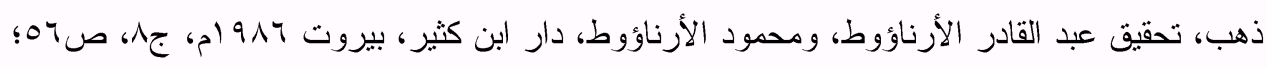

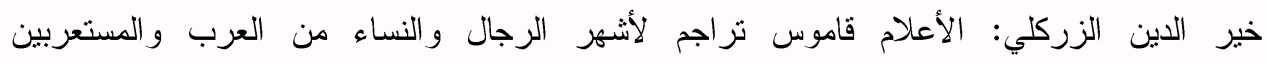

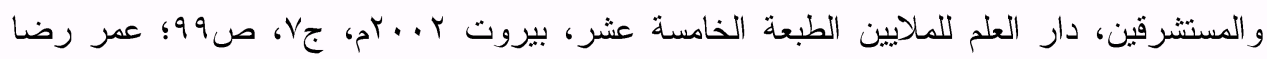

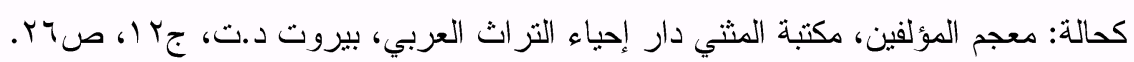

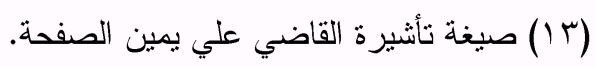

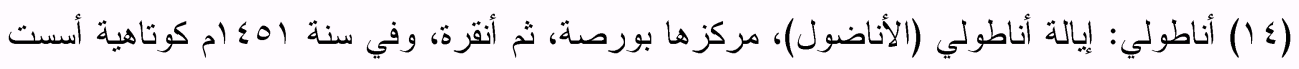

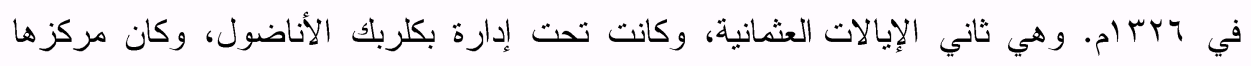

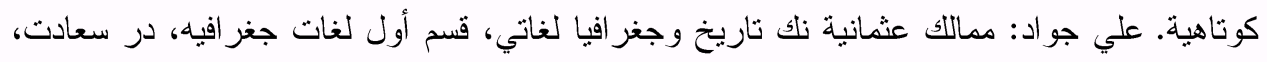

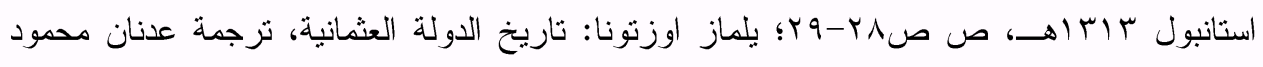

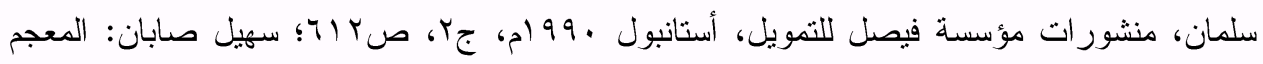

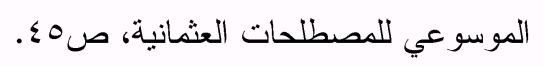
(10) في الأصل بالثكل الإملائي ذخايرها، و هذا يعد إبدالاً. 
وعوار مردودة وأمور تمور وأحوال تحول فالسعيد من أتعظ بغيره وأعتد زاد المعاد

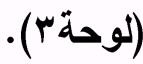

وجه الورقة الثالثة: بخيره وميره قال عليه السلام الدنيا خضرة حلوة فمن أخذها

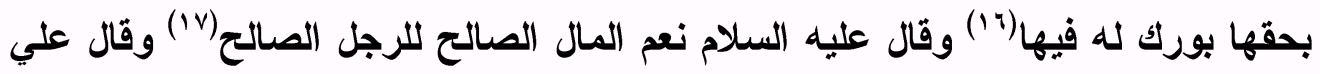
بن أبي طالب كرم الله وجهه الدنيا دار صدق لمن صدقها ودار موعظة لمن فهم عنها ودار غنى لمن تزود عنها مسجد أولياء الله ومهبط وحيه ومصلى ملايكته ومتجر أوليائه

(7 (1) قال العر اقي: رواه الترمذي وابن ماجة من حديث أبي سعيد دون قوله إن بني إسر ائيل إلى آخره

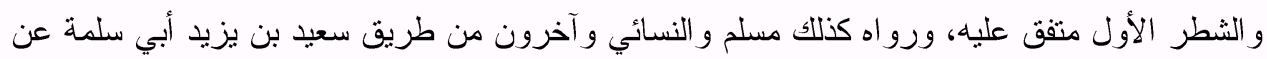

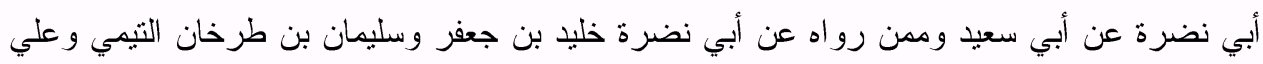

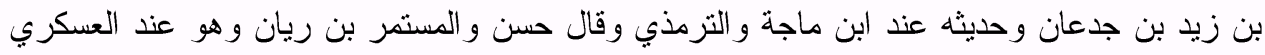

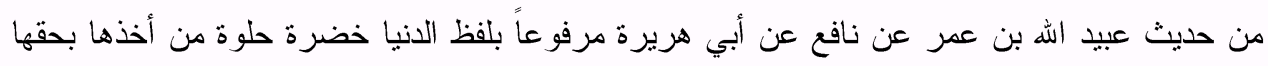

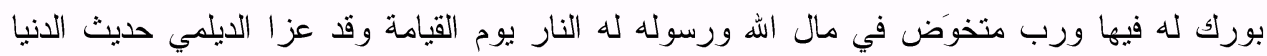
خضرة حلوة وإن رجالاً ينخوّضون إلى البخاري عن خولة و الذي فيه من حديثها الجملة الثانية خاصة

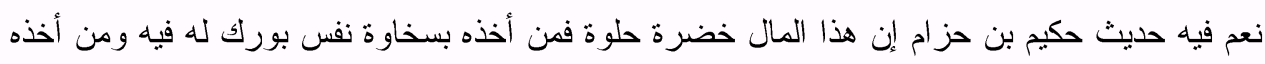

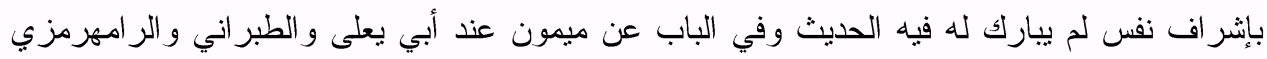

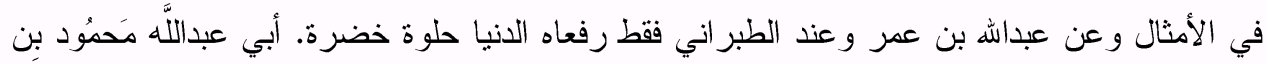

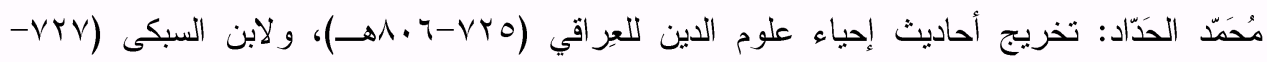

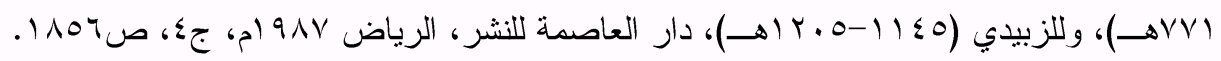

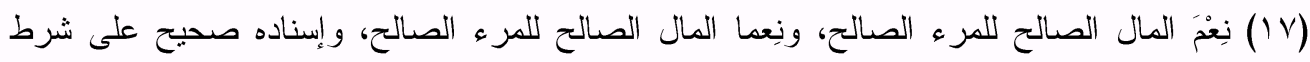

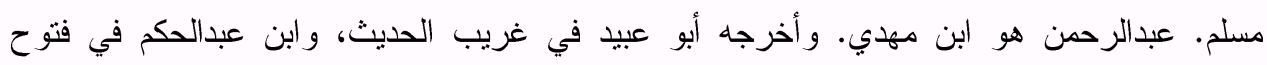

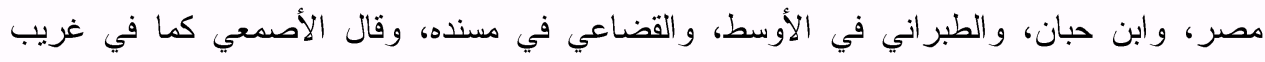

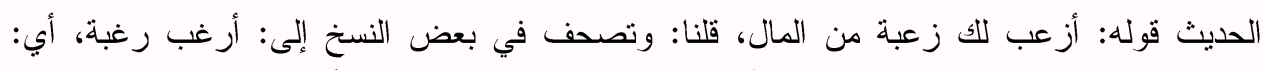

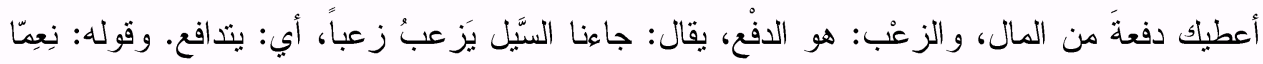

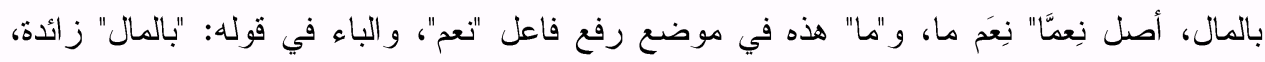

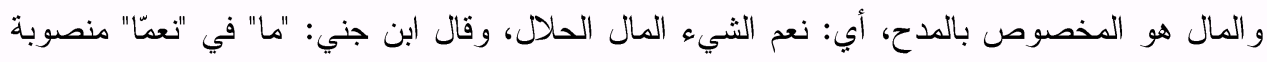

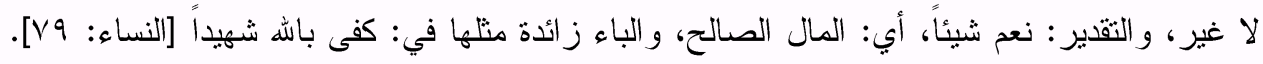

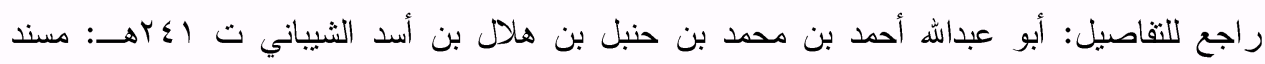

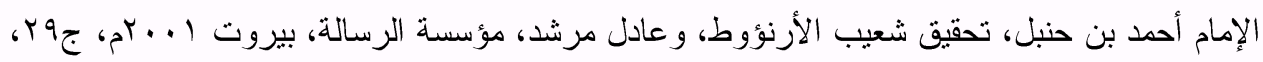


اكتسبوا فيه الرحمة وربحوا فيه الجنة(^) وعن عبدالرحمن بن عوف رضي الله عنه أنه

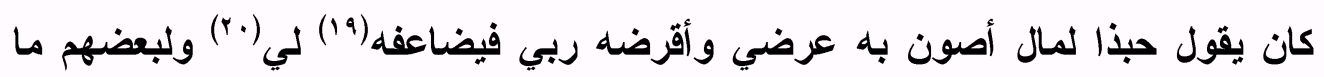

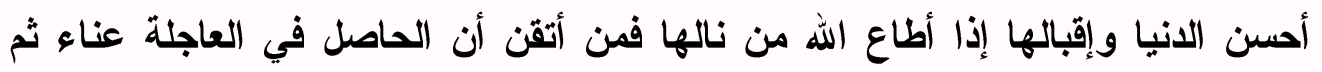

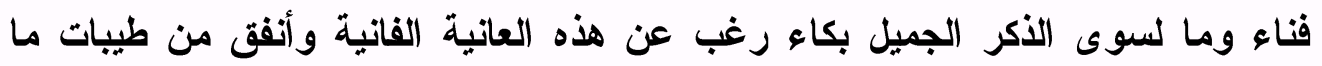

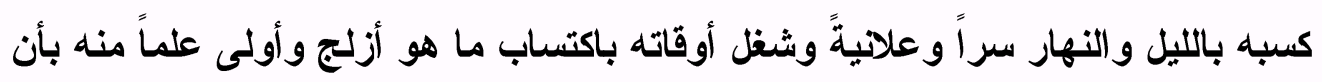
الآخرة خير له.

ظهر الورقة الثالثة: من الأولى وممن اختار الآجلة على العاجلة بنفس جاهدة

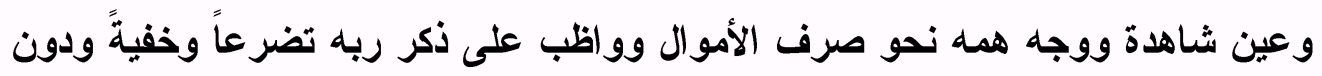

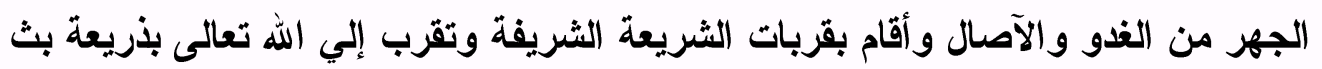

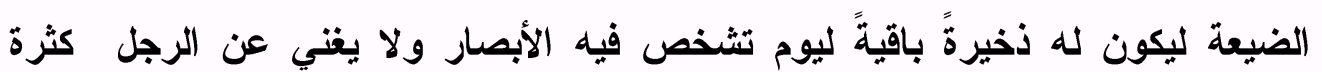

(1) ذكر أمير المؤمنين علي رضي الله عنه الدنيا فقال: اهي دار صدق لمن صدفها، ودار عافية لمن فهم عنها، ودار غنى لمن نزوّد منها، وهي مسجد أحبّاء الله، ومهبط وحيه، ومصلى ملائكته، ومتجر

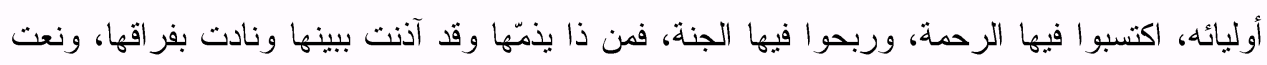

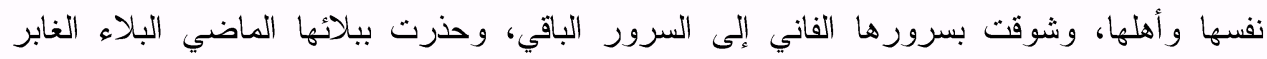

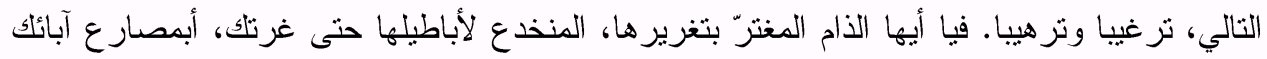
للبلا؛ أم بمضاجع أمهانك تحت الثرى؟ فهذا أحسن ما روي في مدحها. عبدالملك بن محمد بن إسماعيل

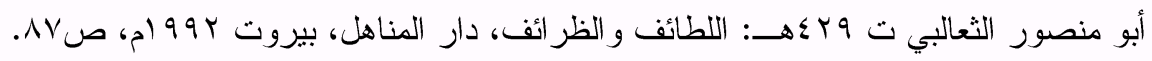

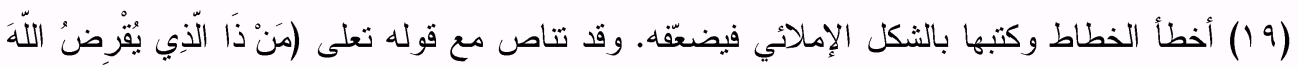

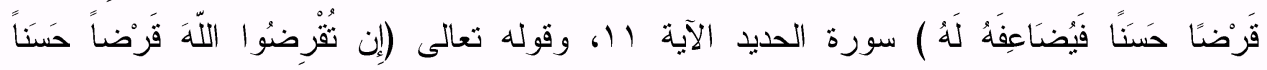

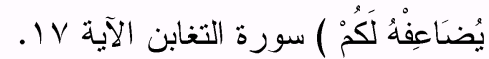

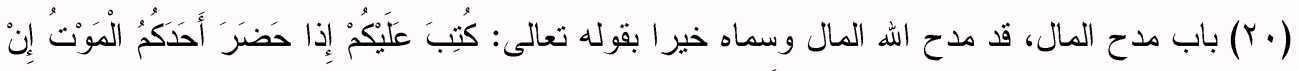

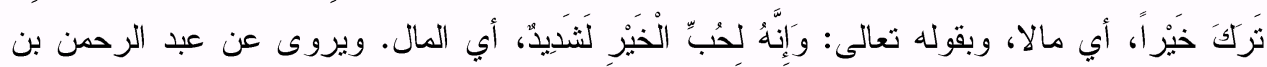

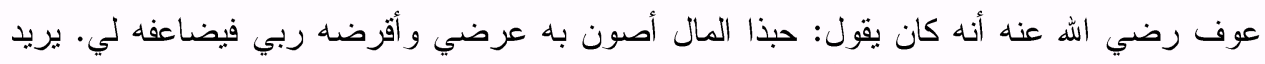

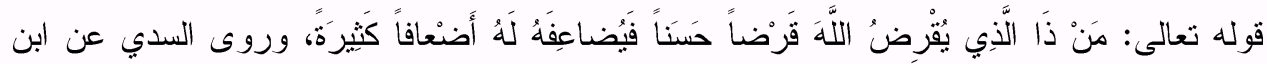

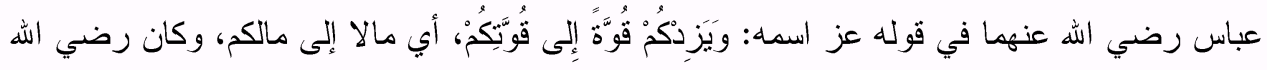
عنه يقول: قد يشرف الوضيع بالمال. ويقال: المال تكسب أهله المحبة، لا مجد إلا بمال، ولا حمد إلا

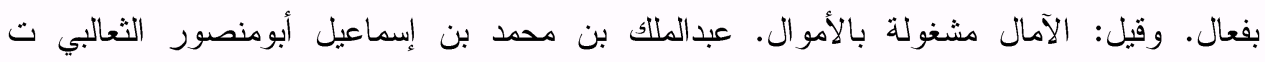

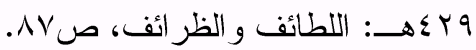




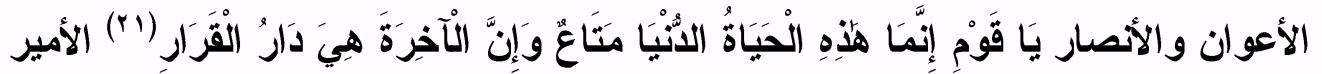
الكبير ذو الثأن الخطير فخر الخواص والمقربين مقبول الملوك والسلاطين مقرب العضرة العلية السلطانية مرضي السدّة السنية الخاقانية صاحب النفس القدسية والكمالات

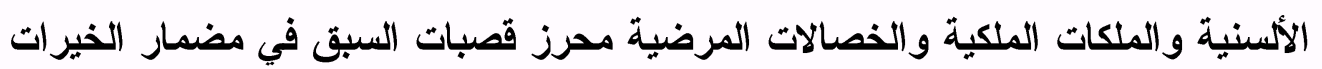
و الحسنات فارس ميدان العطايا والمبرات كهف الفقراء.

وجه الورقة الرابعة: وملاذ الغرباء الأغر الأكرم والأعز المفخم رئيس خدمة

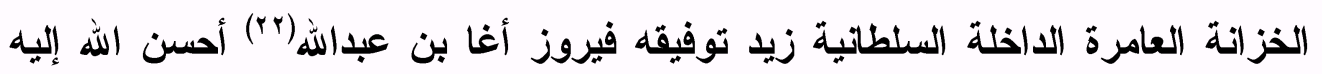
وتقبل حسناته بقبول حسن وجزاه خير الجزاء عن مبراته ما ظهر منها وما بطن وجعله

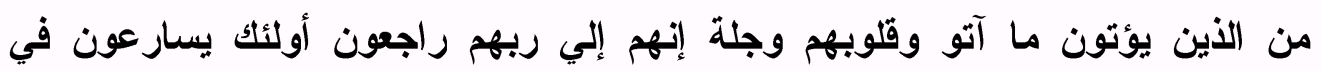
الخيرات وهم لها سابقون عتيق السلطان الأعظم والخاقان الأكرم الأعلم سيد سلاطين العرب والعجم مالك رقاب الأمم الواجب إطاعته ومتابعته علي الأمم سلطان الغزاة و المجاهدين قهرمان الطغاة والمعاندين السلطان بايزيد خان خلا الله سبحانه ملكه وسلطانه ابن السلطان الأعظم والخاقان الأعدل الأكرم سلطان الغزاة والمجاهدين قاهرئ وائرين أكابر الجبابرة والمتمردين مظهر جلال الله وجماله (لوحة ؟).

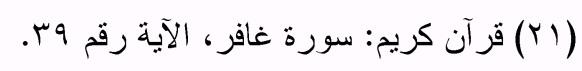

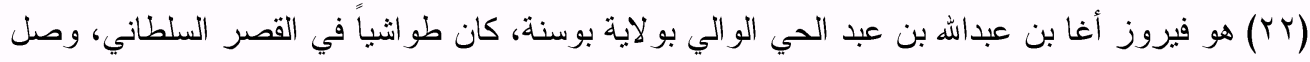

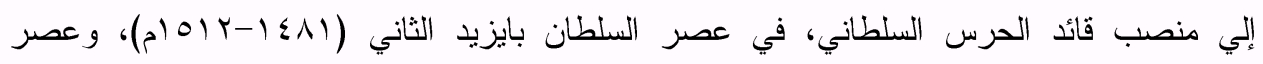

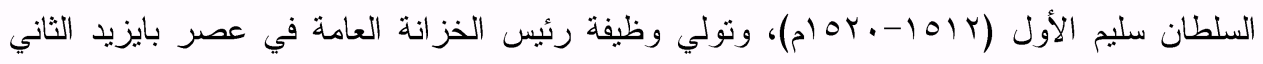

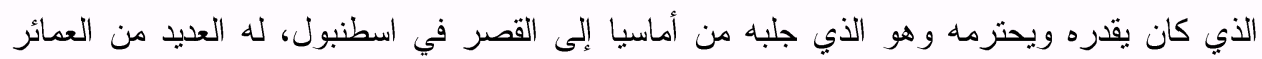

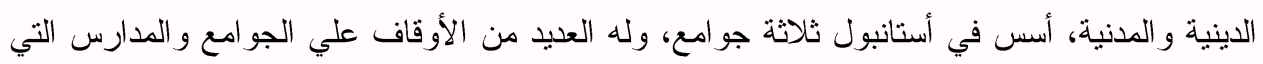

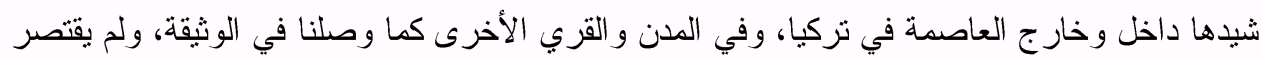

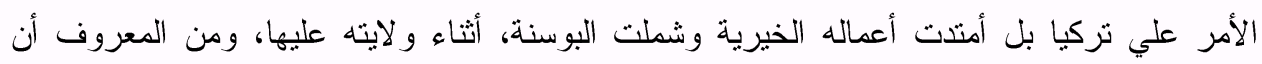

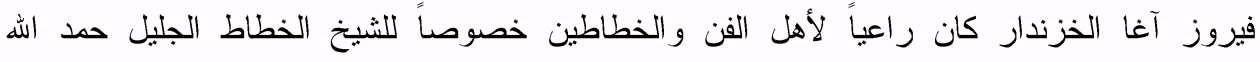
ABD.SSEIIM ULUIAM: KLASiK DÖNEM OSMANLI MiMARiSi, in Osmanl, Kültür Ve Sanat, Yeni Türkiye Yayınları, Ankara 1999, Cilt:10, P. 175; Evgeni RadusheV, Svetlana IVanova, Rumen KoVachev: INVENTORY of Ottoman Turkish Documents about Waqf Preserved in the Oriental Department at the St St Cyril and Methodius National Library, Sofia 2003, Vol.1, P.221. 
ظهر الورقة الرابعة: في البرايا ورحمة الله الفايضة(rآ) علي الغرباء والرعايا

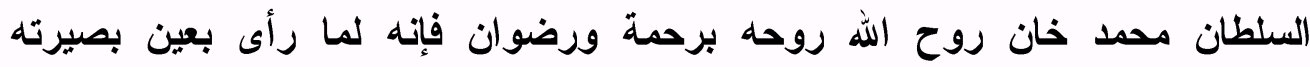

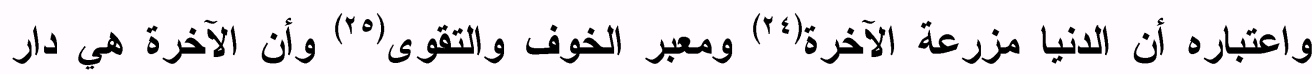

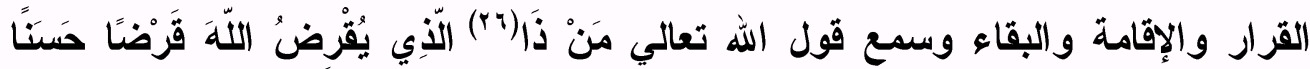

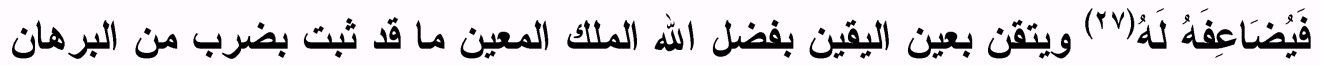

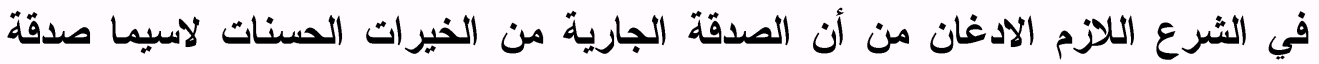

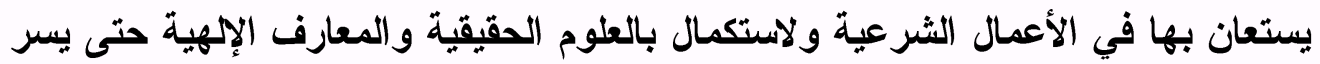

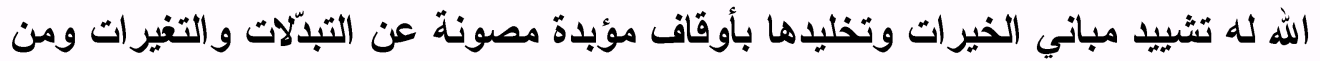
جملتها التي عجزت عن أن يصفها ألسنة النحرير والبيان مدرسة.

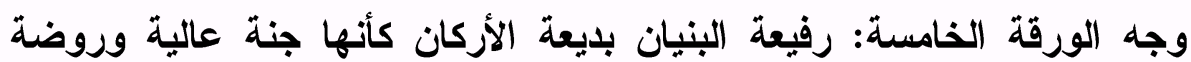

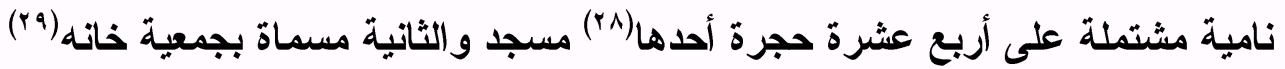

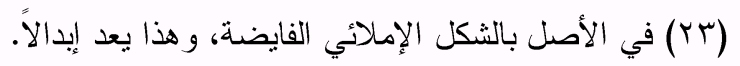

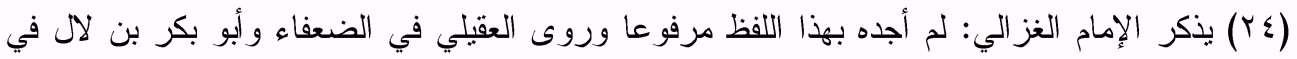
مكارم الأخلاق، من حديث طارق بن أثير، نعمت الدار الدنيا لمن تزود منها لآخرته الحديث وإسناده ضعيف، فصار حفظ الانيا أيضا مقصوداً تابعاً للدين لأنه وسيلة إليه و المتعلق من الدنيا بالآخرة شيئان

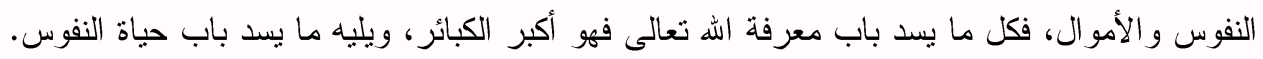

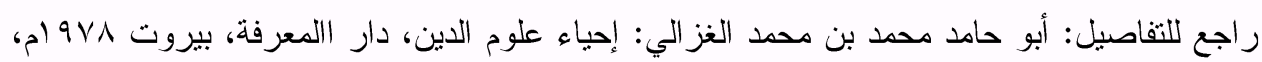

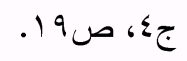

r (ro) أخطأ الخطاط وكتبها بالثكل الإملائي التقاء.

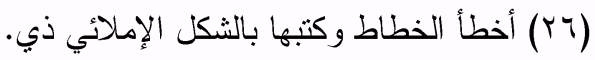

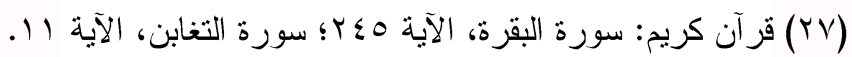

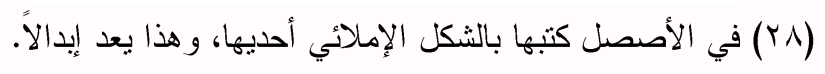$$
\text { (Yq) في الأصل كتبها بالثكل الإملائي جمعيت خانه. }
$$ 
أنشأها حسبةً(·r) لله تعالي وطلباً لمرضاته في باطن قصبة حوضه("r) من قصبات الروم حرص الله بلادها عن البليّات علي الخصوص والعموم وهي مستغنية عن فئن التعريف والتحديد لغاية الثهرة ونهاية المعرفة عند أهاليها ومن جمل جميل خيراته

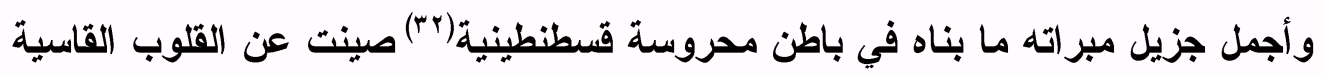

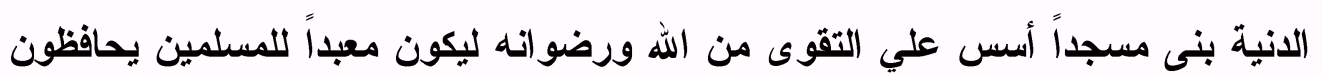

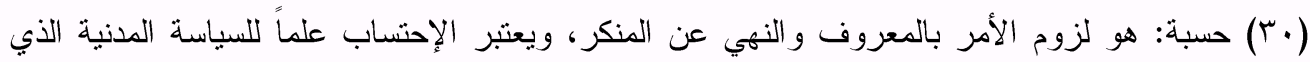

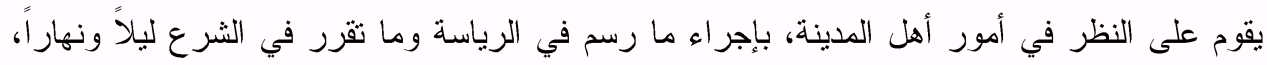

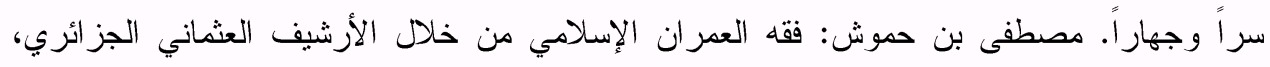

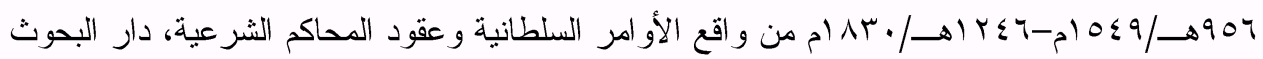

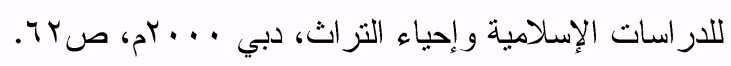

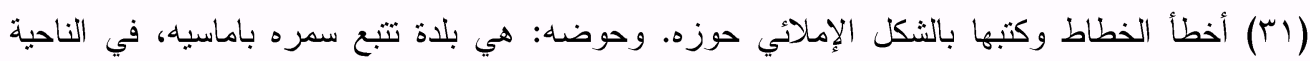

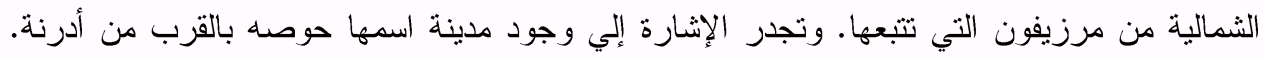

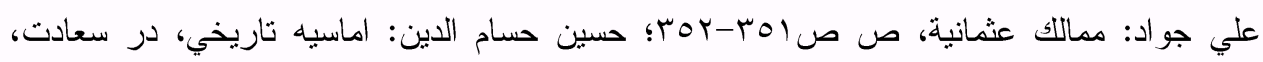

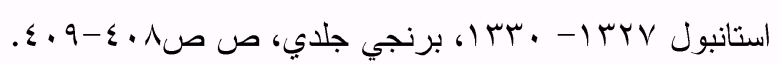

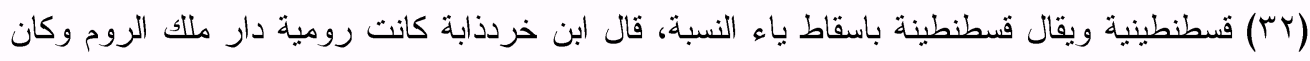

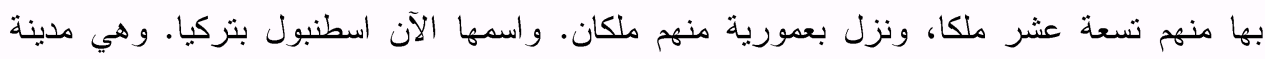

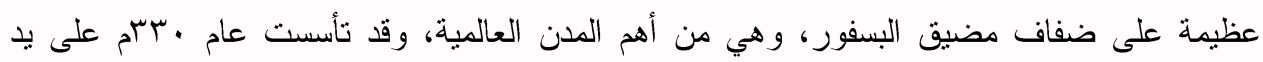

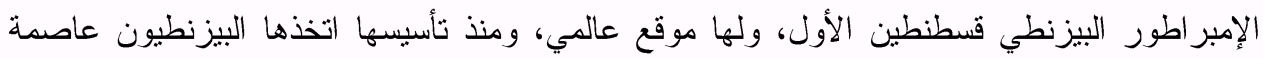

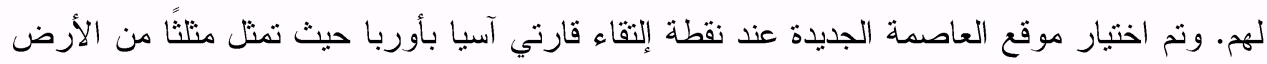

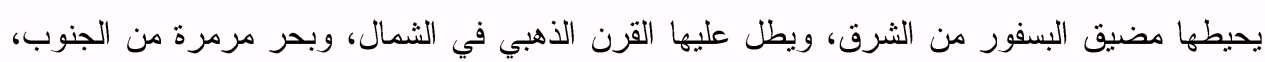

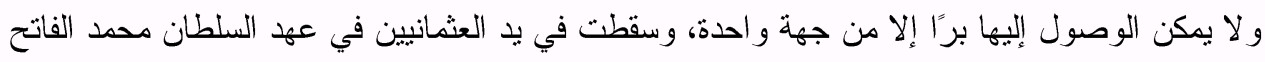

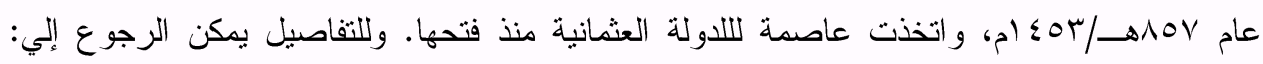

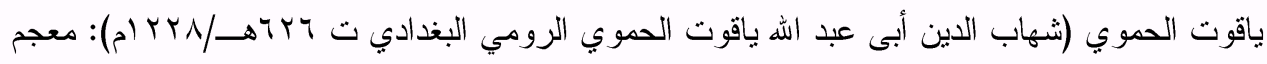

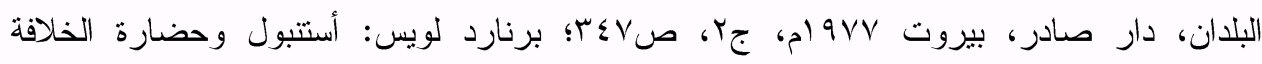

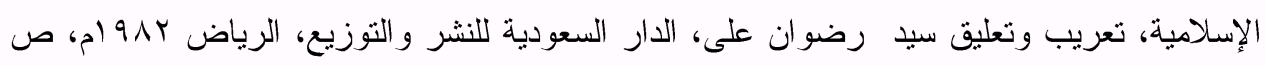

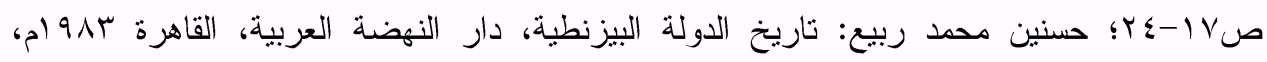

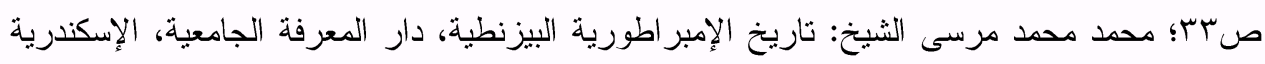

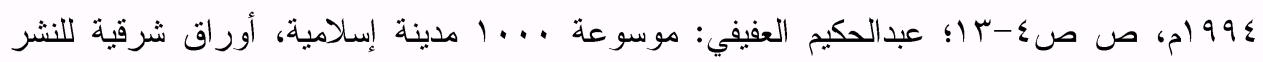

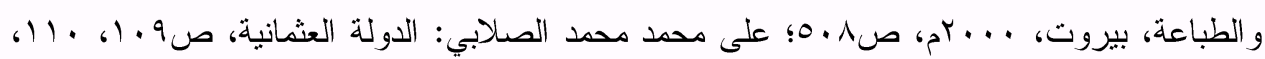


على عبادة الرحمن(rT) ومنها مكتب شريف للأيتام من الصبيان ليتعلموا فيه القرآن وهذا المكتب النظيف في جنب ذلك المسجد الثريف الملاصث للموضع اللطيف المسمي. ظهر الورقة الخامسة: بآت ميداني(๕) ثم وقف وحبس تلثك المدرسة الثريفة على أهلها من الطلبة المستفيدين للعلوم الثرعية النقلية والفنون المرعية العقلية ليسكنوا فيها ويشتظلوا بالتحصيل والأعمال الصالحة ويمتنعوا عن التعطيل والأفعال

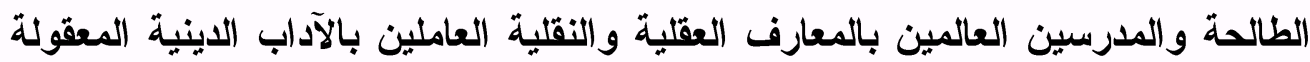
المنقولة ليحضروا هنالك لدى الاشتغال بالتدريس والتعليم في الغدو والآصال ووقف بـ

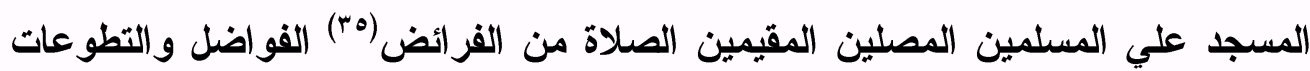
و النوافل ووقف المكتب الثريف على من يتعلم فيه من الأيتام الصبيان القرآن المجيد بالترتيل والتجويد وعلى معلم صالح يعلمهم القرآن والكتاب بالتأديب والتكريم في أيام

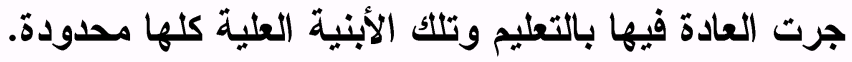
وجه الورقة السادسة: بحدودها الأربعة المشهورة غير محتاجة إلى ذكر حدودها

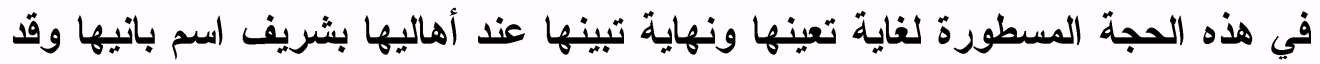

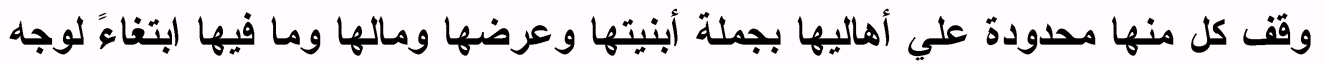

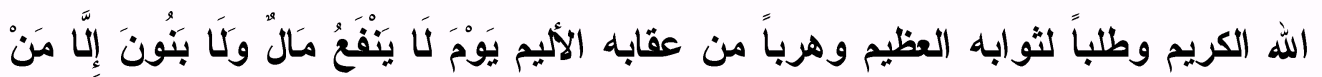

$$
\text { ( (rس) في الأصل كتبها بالثكل الإملائي الرحمان، وهي كتابة مصحفية. }
$$

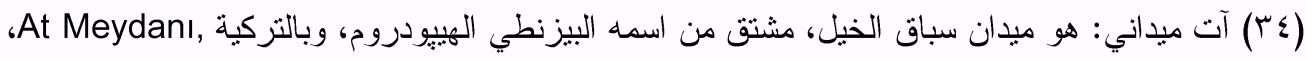
[Sultanahmet]، وهو أكبرميدان في القسطنطينية، شيده قسطنطين عند بناء عاصمته عام . بآم، ولقد كان ينتصف المدينة هو والقصر الملكي وكنيسة أياصوفيا، وهذا الميدان كان سيركاً ومركز فئن

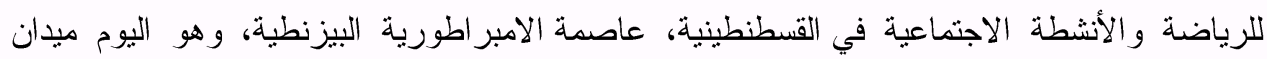

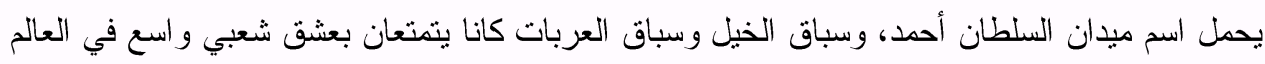

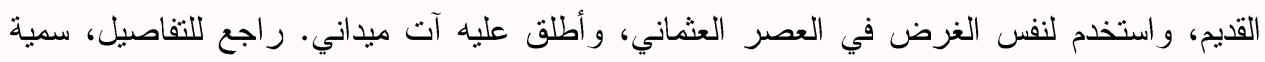

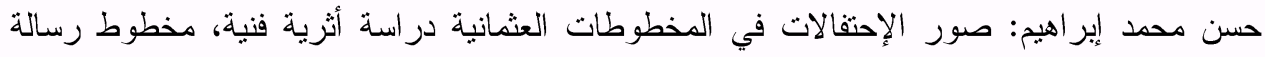

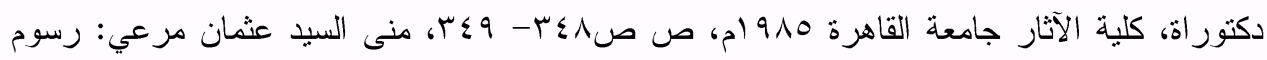
عمائر مدينة إستانبول من خلال تصاوير المخطوطات العثمانية، مخطوط رسالة ماجستير، كلية الآثار

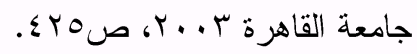

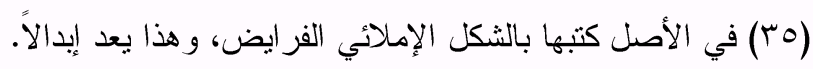




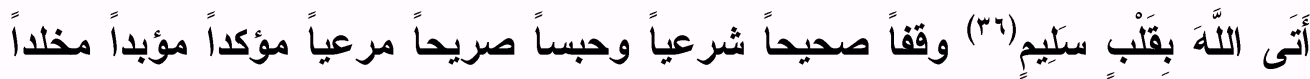
بفضل الله من الواقف المومئ إليه حسناته ومبراته وبلغه أقصي ما يتمناه من درجاته ومقاماته ثم أن الواقف المشار إليه وقف وحبس وسبل وتصدق على مصالح تلك الأبنية

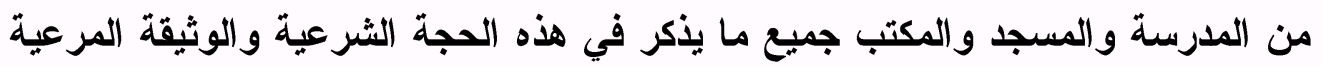
من القرى والضياعات وحصص القرى والعقار ات.

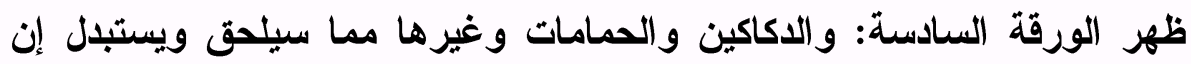

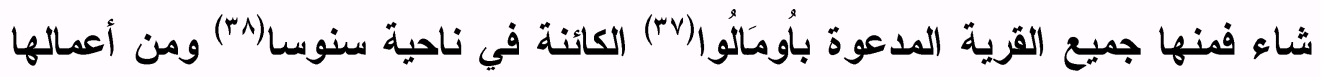

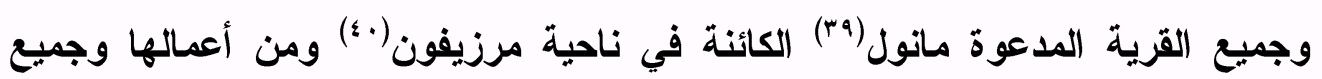

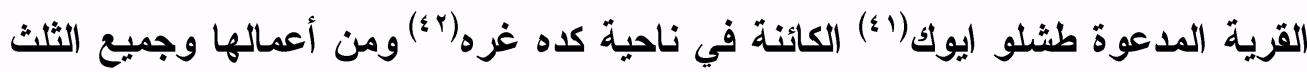

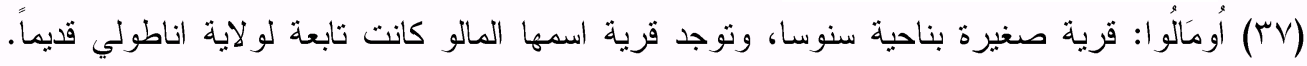

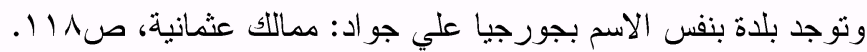

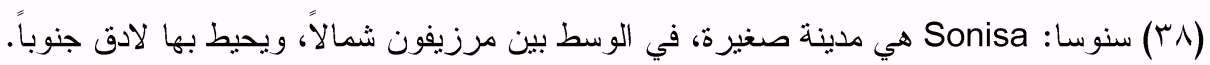

Huri Islamoglu-Inan: State and Peasant in the Ottoman Empire, Agrarian Power Relations and Regional Economic Development in Ottoman Anatolia During the Sixteenth Century, E.J. Brill, New York 1994, P. 251, Map 2.

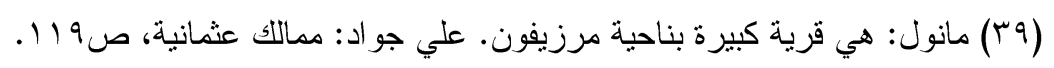

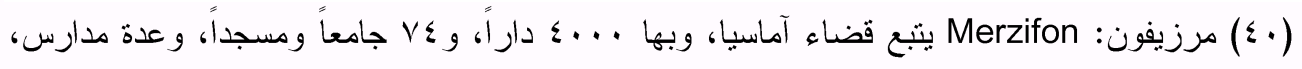

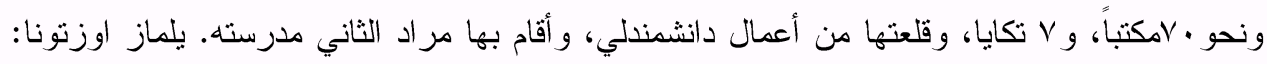

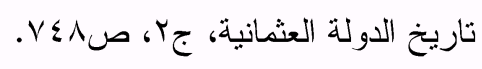

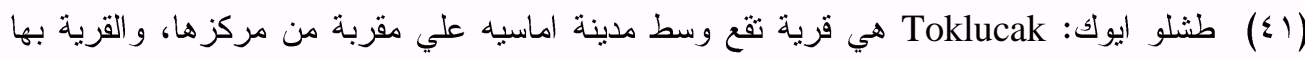

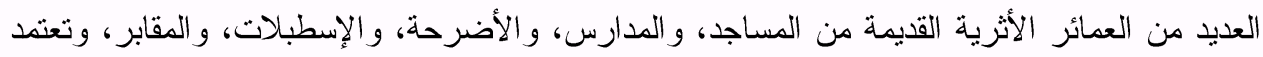

$$
\text { القرية علي الزر اعة نظر اً لخصوبة أر اضيها. }
$$

http://www.koylerimiz.info/amasya/merkez/koy

(ץ) كده غره: أخطأ الخطاط وكتبها بالثكل الإملائي كدغره. وكده كلمة سلجوقية الأصل، تثشير إلي جهة

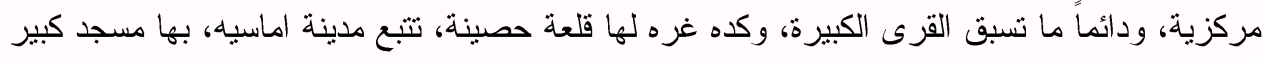

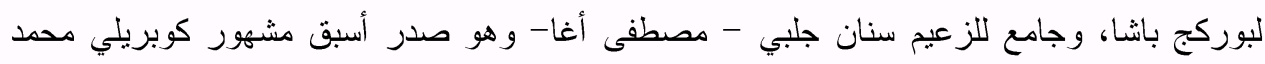

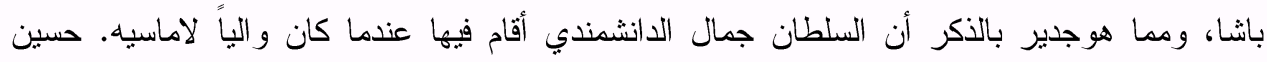

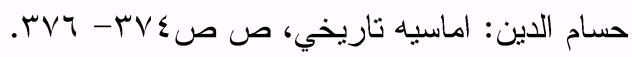




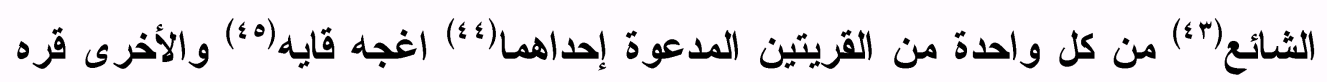

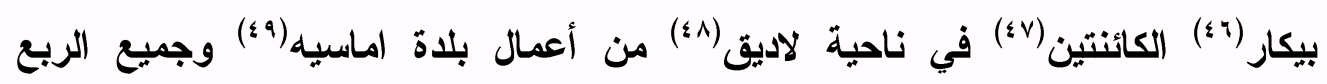

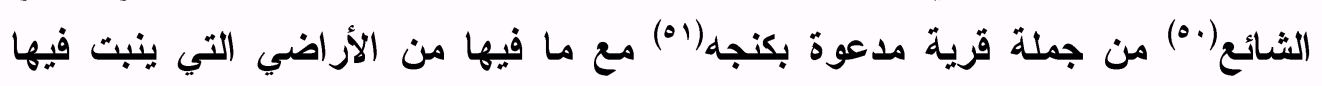

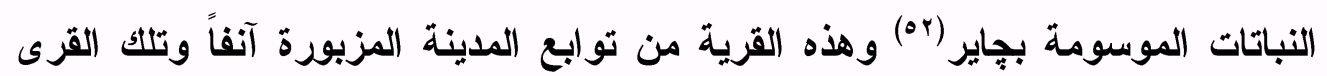

$$
\begin{aligned}
& \text { (4) في الأصل كي كتبها بالثكل الإملائي الثايع، و هذا يعد إبدالاً. }
\end{aligned}
$$

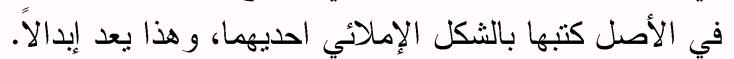

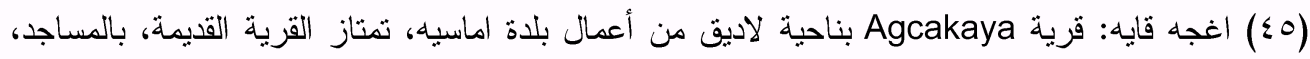

$$
\text { و المدارس، و الأضرحة، و والمقابر ، و الإسطبلات. }
$$

http://www.koylerimiz.info/samsun/ladik/koy-20870-agcakaya-koyu.

قره بيكار: akyar هي قرية صغيرة تابعة للاديق وتبعد عنها ستة كيلومترات، وتتبع محافظة

$$
\text { سامسون، وتثتهر بالآثار الاسلامية المختلفة، الدينية، و المدنية. }
$$

http://www.koylerimiz.info/samsun/ladik/koy-20871-akyar-koyu.

(\&V)

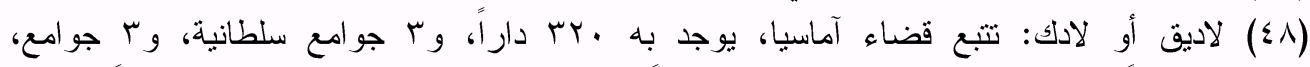

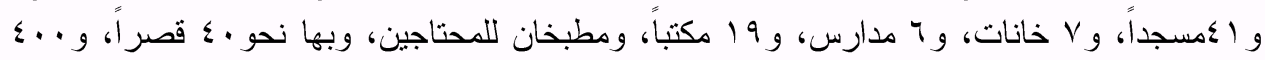

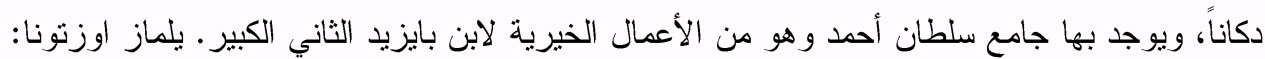

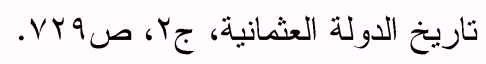

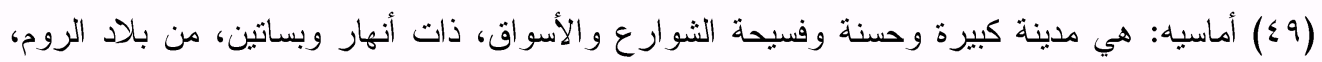

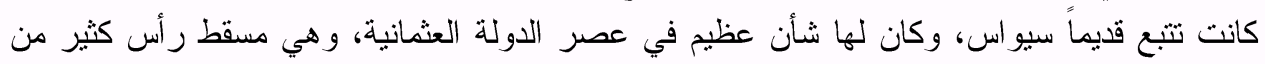

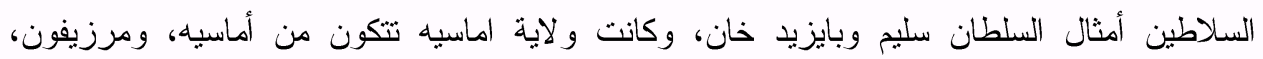

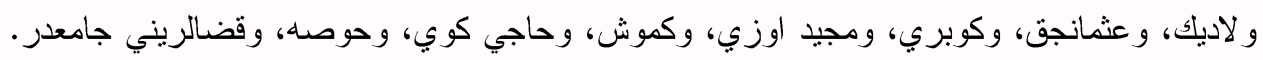

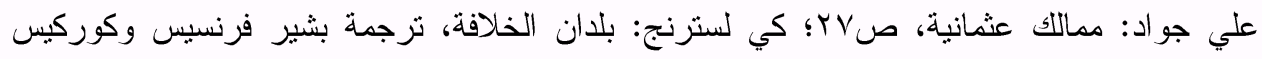

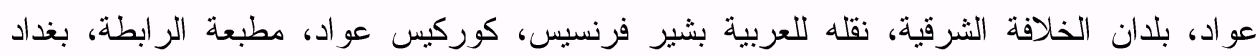

$$
\text { ( }
$$

ILLHAN ŞAHIN - FERIDUN EMECEN: AMASYA Karadeniz bölgesinin iç kesiminde Şehir ziyaretinde bu Şehrin merkez Olduğu il. İslam Ansiklopedisi, Ankara 1991, cilt 3. S. 1-4.

$$
\text { (0) (0) في الأصل كتبها بالثكل الإملائي الشايع، وهذا يعد إبدالاً. }
$$

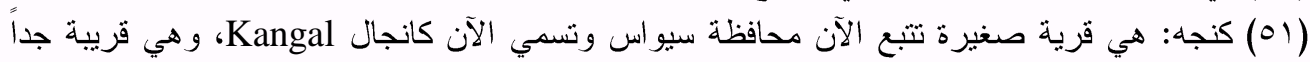

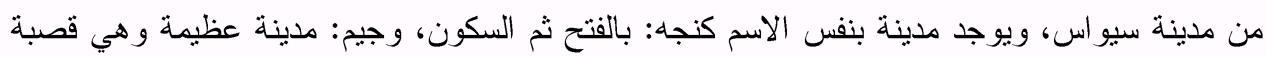

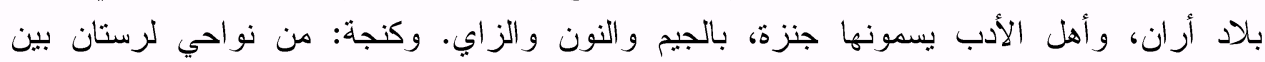

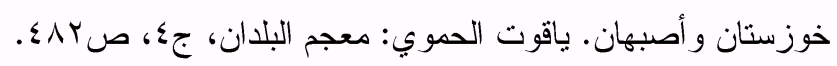
http://www.e-sehir.com/turkiye-haritasi/sivas-kangal-ilce.

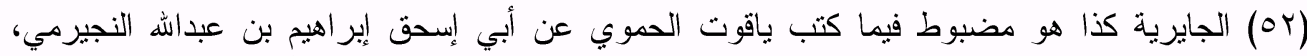

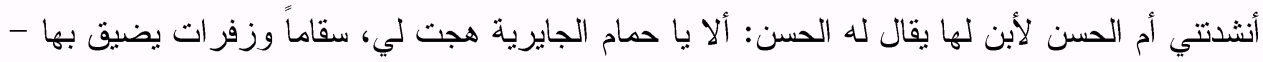


الست مستغتية كلها عن التعريف والتحديد لشهرتها في أمكنتها عند أهاليها ومنتقلة إلي الواقف المزبور علي وجه المسفور بالشراء الصحيح الشرعي. وجه الورقة السابعة: من مولانا بيري بن طورسون (ro) على ما نطق به الكتاب الشرعي الصادر عند المولي المعظم قدوة العلماء الكرام عمدة الفضلاء الفخام المولي المكرم مولانا إبراهيم جبي قاضياً بالعسكر المنصور الثابت مضمونه لاى الحاكم الموقع أعلاه ومنها جميع الثمن الثائع(ء) في جملة قرية لاديق بإكنجيسي(ه) الكائنة بناحية لاديق من أعمال اماسيه المستغتية عن التحديد والتعريف لشهرتها في مكانها المنتقلة إلي الواقف المسفور بالشراء الصحيح الشرعي من الحاج يونس بن علي فقيه على ما نطق به الكتاب الحكمي الثرعي الصادر عن مولانا بير حسن بن عز الاين قاضباً بمحروسة

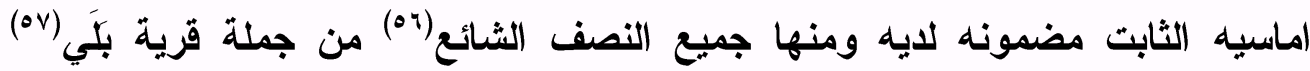

=صدري، فقالت حمام الجايرية ما أرى علي إذا ما مت، يارب من وزر. وتجدر الإثارة إلي أن هناللك

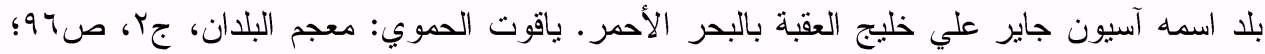

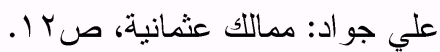
(ro) طورسون الرومي: ختن المولي أده بالي، قال قي القائق النعمانية، هو من بلاد قرمان، قرأ على المولى أده بالي، التفسير، و الحديث و الأصول، وتفقه عليه، وقام في مقامه في أمر الفتوى، وتدريس باليس العلوم الثرعية، وتدبير أمور السلطنة، وكان عاملاً عالماً مجاب الدعوة، كذا ذكره من غير أن بؤرخ لوفاته و لا مولده. تقي الدين عبد القادر التميمي الداري الحنفي ت • 1 ـ اهــ: الطبقات السنية في تراجم

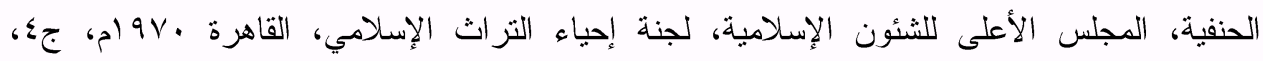
ص ص110 (ـ 0) في الأصل كتبها بالشكل الإملائي الثايع، وهذا يعد إبدالاً.

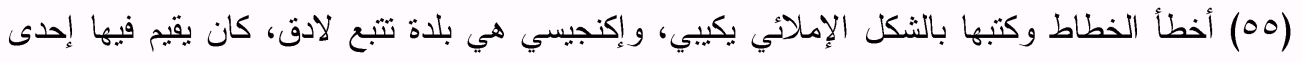
السلالات السلجوقية، التي تسمى إيكنجيسي سلالة، ذات الثهرة الكبيرة في التاريخ العثماني، ومنها السلطان محمد خان، ومن الثخصيات الثهيرة التي تتسب لها سيدي أحمد الرفاعي، و أحفاده المنتشرة

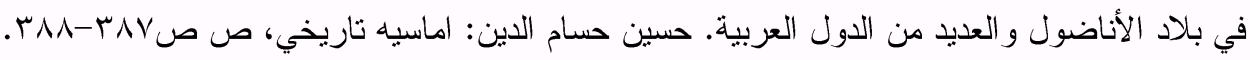

$$
\text { (70) في الأصل كتبها بالشكل الإملائي الشايع، و هذا يعد إبدالاً. }
$$

(oV) بالي: هي قرية تتبع حوضه التي كانت تتبع قديما مرزيفون، وجدير بالذكر أن مرزيفون كان بيكون

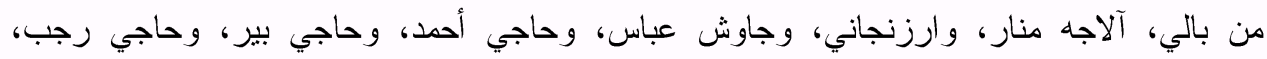

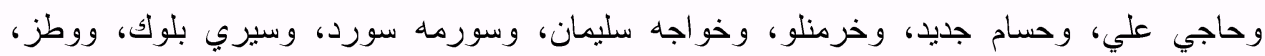

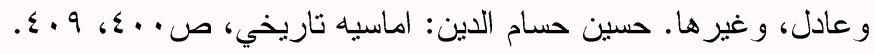


وثيقة وقف شرعية عثمانية دراسة أثرية حضارية

الكائنة بناحية حوضه(ه) الكائنة في سمره(ه) من أعمال مدينة اماسيه المستغنية عن التعريف و التحديد.

ظهر الورقة السابعة: لشهرتها في مكانها بين أهاليها المنتقلة إلي الواقف

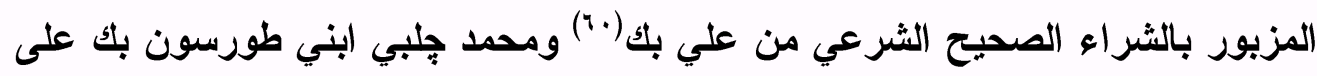

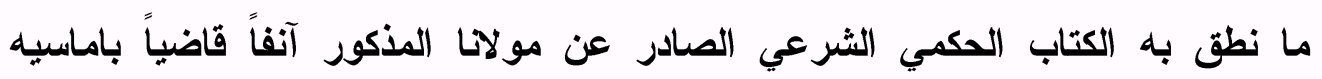
المحروسة الثابت مضمونه لايه ومنها جميع القرية المسماة بجاير كوي(1") من أعمال

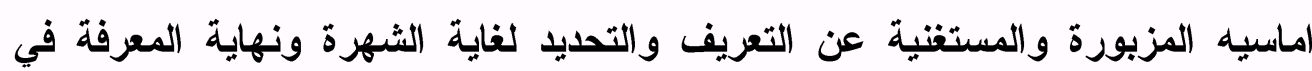
مكانها عند أهاليها المنتقة إلي الواقف السالف اسمه السامي بطريق الثراء الصحيح

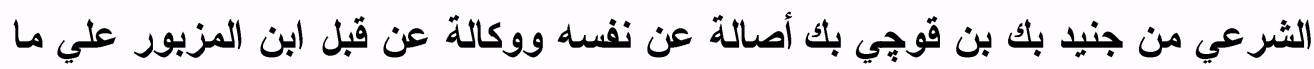
نطق به الكتاب الحكي الثرعي الصادر عن المولي المعظم مولانا إبراهيم جلبي قاضياً

(01) أخطأ الخطاط وكتبها بالثكل الإملائي حوزه.

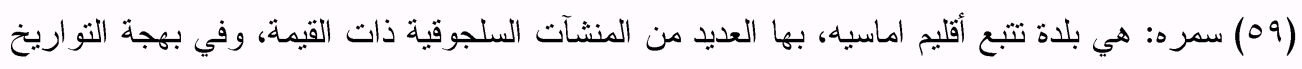
يذكر شكر الله أن سيمره بكسر أولها حرف السين وسكون الميم وراء مهملة، وجدير بالذكر أن هنالكا

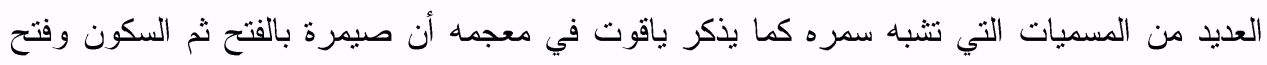

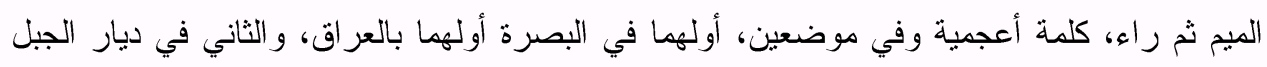

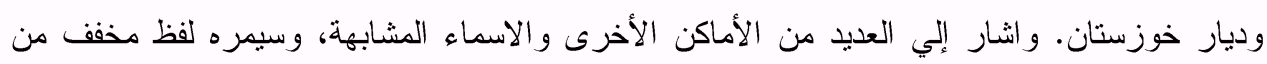

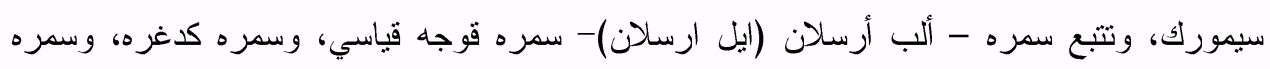

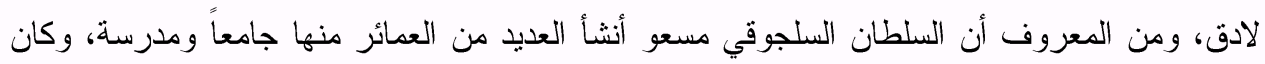

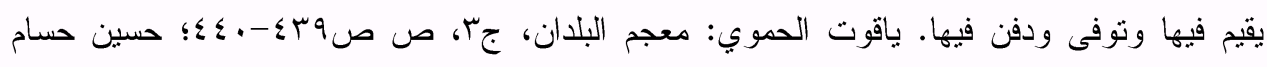

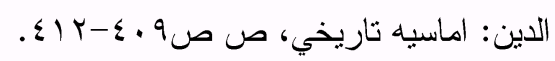

(7) بك: كلمة تركية من بيوك أي كبير ، أما بيك بياء مثناه تحتية بعد الباء الموحدة التحتية فهي خطأ

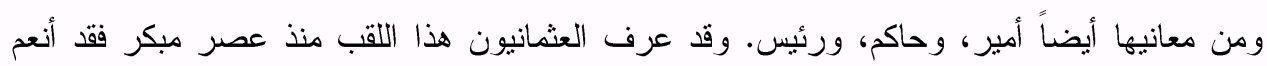

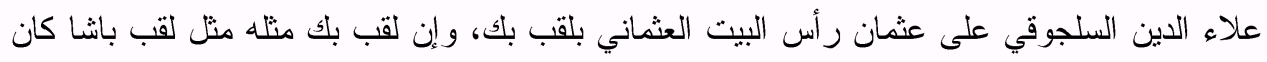

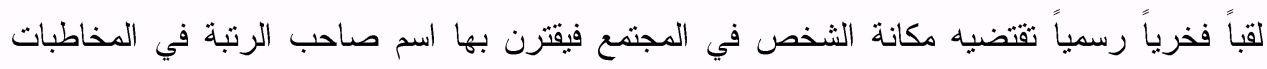

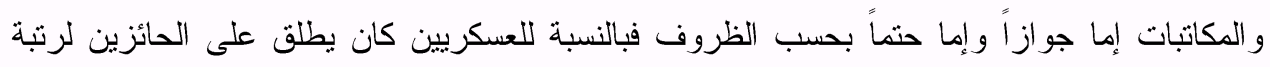

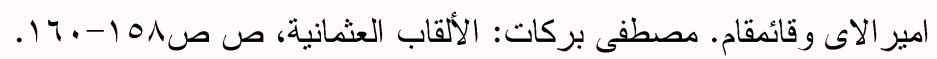
(7) (7) كوي تعني باللغة التركية العثمانية قرية. 


\section{بالعسكر المؤيد الثابث مضمونه لايه ومنها جميع القرية المدعوة بموراميل(rآ) مع} طرفيها.

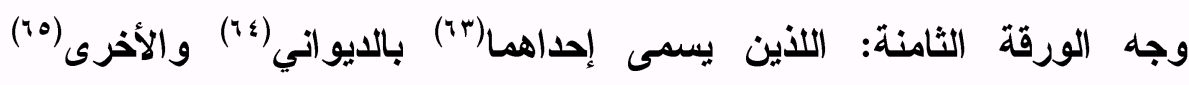
بمالكانه(זr) من أعمال اماسيه المزبورة المستغتية عن التعريف والتحديد لغاية الشهرة

( (T) لم أعثر علي تعريف بمور اميل؛ ولكن عثرت على تعريف مور ا: أصبحت إيالة بحرية مستقلة، بعد

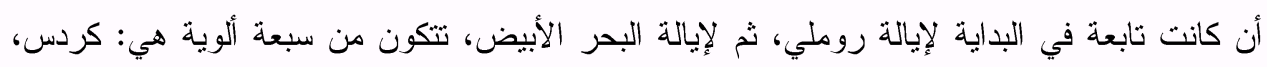

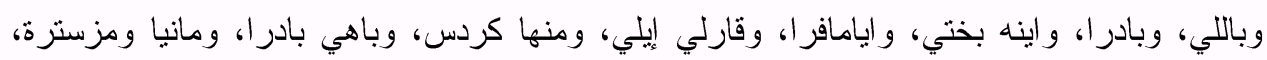

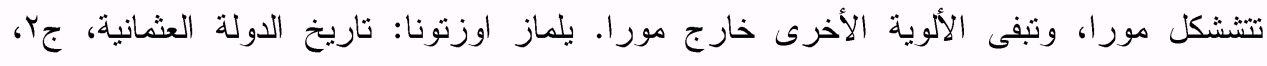

$$
\text { ص (T) VYT) في الأصل كتبها بالشكل الإملائي احديهما، و هذا يعد إبدالاً. }
$$

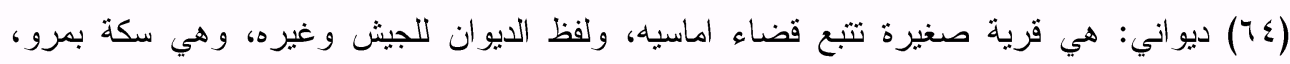
و الديوان أصله دوّان فعوّض من إحدى الواوين ياء لأنه يجمع علي دواوين، ولو ولئ كانت الياء أصلية

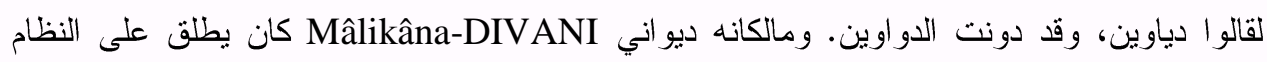

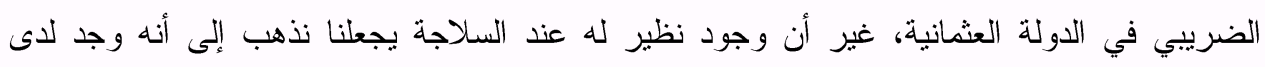

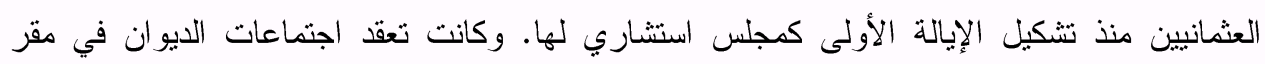
بكلربكي الإيالة، وكما كان الديوان الهمايوني هو المجلس المخول لحكم الدولة كان ديوان الإيالة هو الآخر صورة مصغرة منه، سواء من حيث النركيب أو الصلاحيات المخولة لها في حكم الإيالة. ويضم

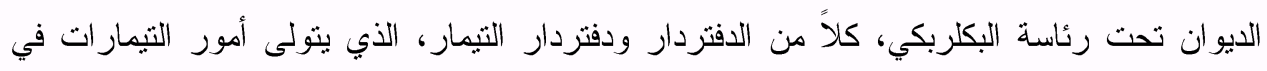
الإيالة، و القاضي الذي ينظر في أمور الشرع و القانون، و أفندي الديوان، و التذكره جي، و والجاويشية، ونية

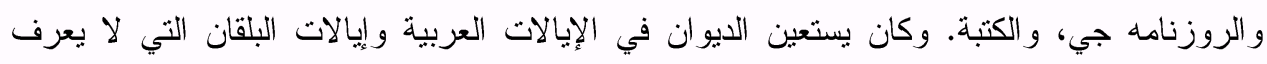
أهاليها اللغة التركية بعدد من المترجمين الذين يجيدون اللغات المحلية، حتى يقوموا بترجمة شكاوى الإلين

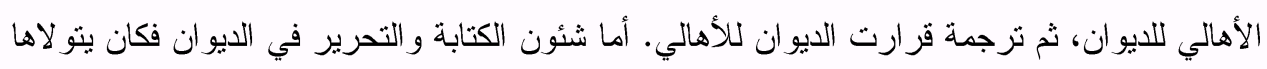

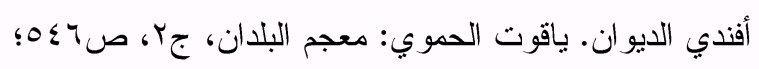

MEHMET GENÇ: MALiKANE-DiVANi, islam ansiklopedisi, ankara 2003, cilt. 27, S. 518-519.

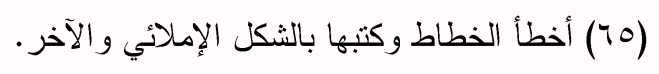

(T (T) مالكانه: Mâlikâna و المعنى المقصود في كلمة مالك هي كلمة مشنقة من المحاصيل وهي فارسية الأصل. ورد هذا الاصطلاح في مصادر العصر العثاني علما على القائمين بتحصيل الضرائب، ثم هئ تحديدها من قبل وزارة الخزانة وكان حجم الضر ائب زيادة أو نقصان، يتو لاها إلى جانب جمع الموائد بعض الوظائف الإدارية في السنجق الذي يقيم فيه. فقد أحدثت الدولة تغير ات على قسم من الزعامات في القرن الثامن عشر، وحولتها إلى ما عرف باسم (مالكانه)، وكلفت المحصلين بتحصيل عو ائد تلكا 
في مكانها عند أهاليها أما جميع الديواني فهو ملث للواقف المزيور بتمليك السلطان الأعظم والخاقان المعظم صاحب السيف والقلم سلطان بايزيد خان بن محمد خان أبد الله عمره وأيد دولته باللطف والإحسان وأما جميع مالكانتها فمنتقل إلي الواقف المائ المسفور بالثراء الصحيح الثرعي من الرجل المدعو بقرجه بن عبدالله وعلي بن الخواجه طورياشا ويوسف بن مرعش والحاج إلياس بن يزيد وعلي بن أحمد جلبي على ما باء نطقت (IV) به الكتب الحكمية الثرعية الصادر بعضها عن المولى المعظم المذكور آنفاً قاضيا بالعكر المؤبد المؤيد الثابت مضمونه لديه وبعضها عن مولانا.

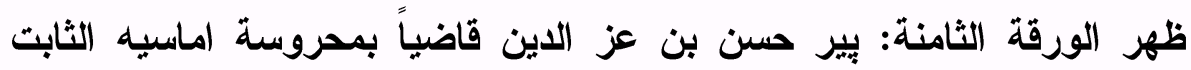

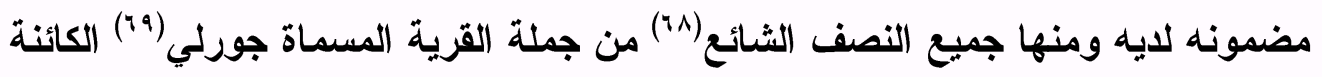
بناحية مرزيفون أباد من توابع اماسيه المزبورة المستفتية عن التعريف والتصديد لغاية الثهرة ونهاية المعرفة عند أهاليها المنتقلة إلي الواقف بطريق الثرائه الثراء الصديح الثرعي من رجل مدعو بيير محمد بك بن جوبان بك أصالة عن نفسه ووكالة عن قبل أخيه نسباً المدعو يوسف بن جوبان بك على ما نطق به في يده من الكتاب الحكمي الثرعي الصادر

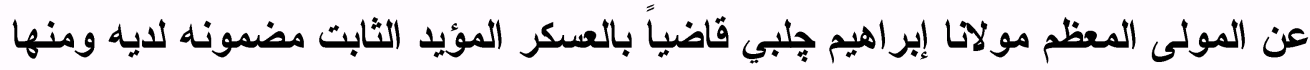

=المالكانات، وجعلتهم من المسئولين عن إدارة السنجق، وبدأ يظهر المحصلون في سناجق عديدة خلال ذلك العهد. وكانو ا عندما يتعثر ذهابهر بأنفسه إلى وظائفه كانو ا يرسلون وكلاء عنهم. وكان وكانت العائلات

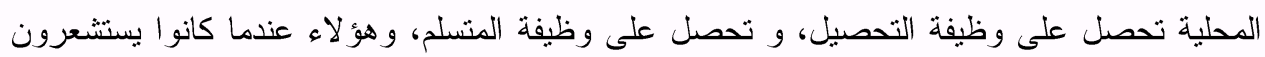
القوة في أنفسهم يقدمون أحيانا على الإختلاس.

MEHMET GENÇ: MALIKANE, islam ansiklopedisi, ankara 2003, cilt. 27, S. 516-518.

$$
\begin{aligned}
& \text { (TV) أخطأ الخطاط وكتبها بالثكل الإملائي نطق. }
\end{aligned}
$$

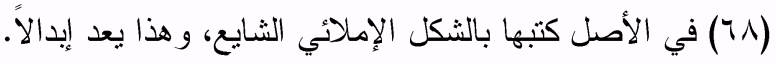

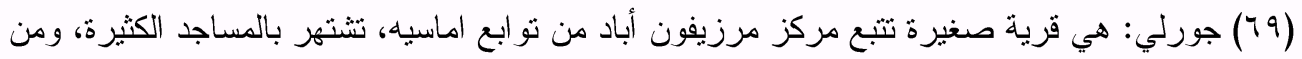

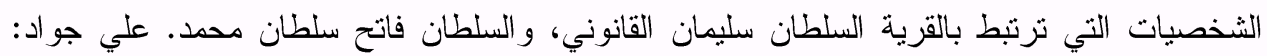


جميع القرية المسماة فورغو(v) الكائنة بناحية ذا النون اوزي(الم) من أعمال

اماسيه المزبورة المستغنية عن التعريف.

وجه الورقة التاسعة: والتحديد لشهرتها في مكانها بين أهاليها المنتقلة إلى الى

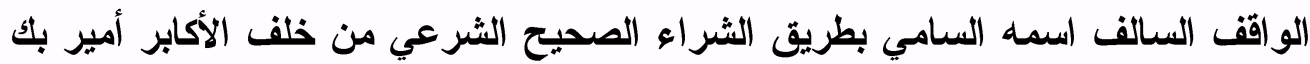

بن المرحوم يعقوب بك بن المرحوم قوج حسين بك على ما نطق به الكتاب الحكمي

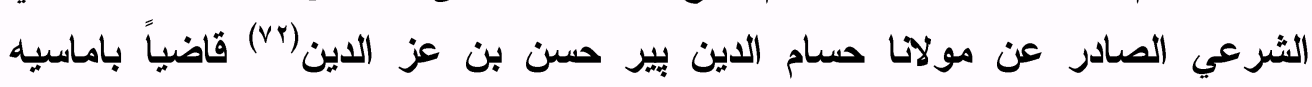
المحروسة الثابت مضمونه لايه ومنها جميع قرية قزلجه الكائنة في ناحية كلاكلان

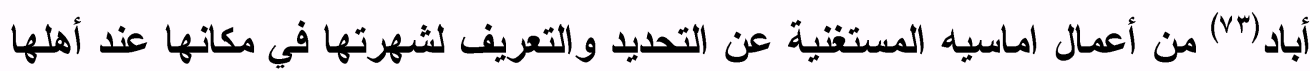

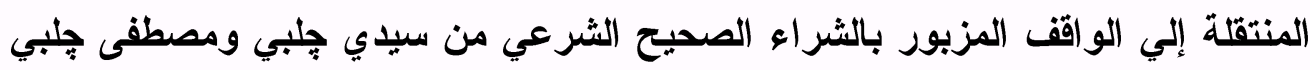
بن المرحوم محمد جلبي ومن علاء الدين أغا بن محمود السراج السلطاني على ما نطق بلى

(P•) فورغو : قرية صغيرة تتبع ذي النون اوزي التي تتبع لادق ضمن اقليم اماسيه. راجع للتفاصيل قرى

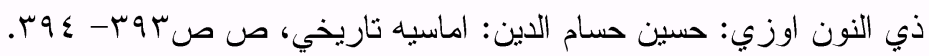

(VI) ذو النون اوزي: هي بلدة تتبع لادق ثقع في الناحية الجنوبية الغربية منها ضمن اقليم اماسيه، وكانت

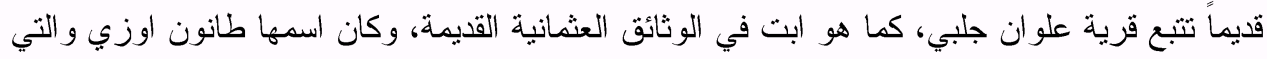
تحولت فيما بعد إلي ذا النون اوزي، ثم ذا النون اباد وذو النون بابا. حسين حسام الدين: اماسيه

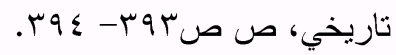

(VY)

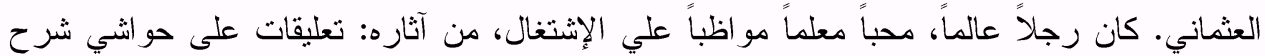
التجريد للسيد الثريف، وتعليقات على أسباب قوس قزح. أصولي، مفسر، محدث، لغوي، شاعر . ولد

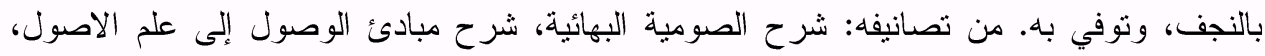
تفسير القرآن الكريم الموسوم بالوجيز في تفسير القرآن العزيز، جامع الشتات في فروق اللغات، و الدرة

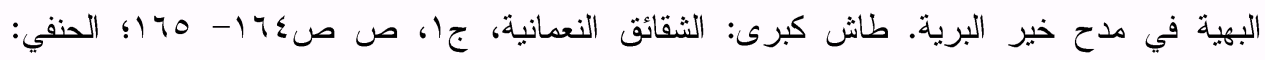

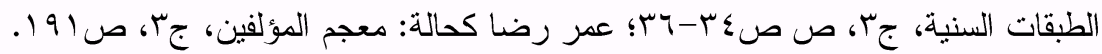
(VT) أماسيه، في الغرب منها، وتعد قرية أورته كوي هي مركز لها، سكنها الدانشمنديون في أوائل عام

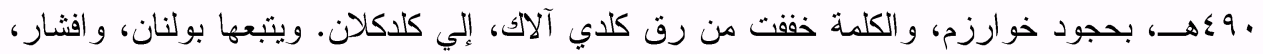

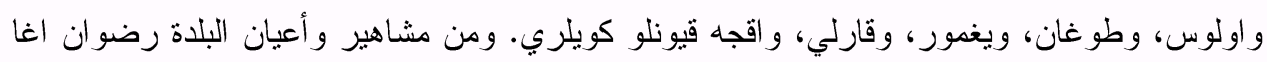

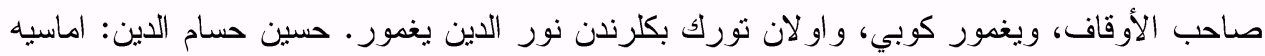


به الكتاب الحكمي الثرعي الصادر عن مولاتا حسام الدين بير حسن بن عز الدين قاضياً باماسيه المحروسة.

ظهر الورقة التاسعة: المزبورة الثابت مضمونه لايه ومنها جميع الحمام الأي بناه الواقف للرجال والنساء بالحكم السلطاني والتوقيع الخاقاني في باطن محروسة

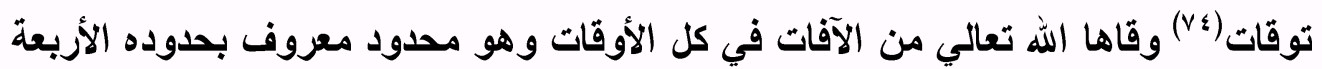

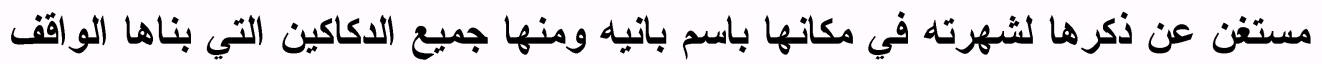

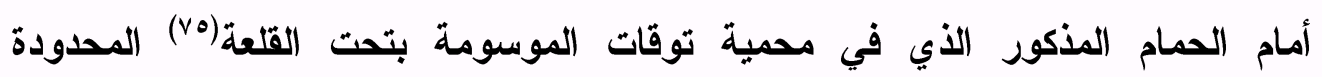
المعروفة بحيث لا تحتاج إلى ذكر حدوها ومنها جميع الحمام الذي بناه في باطن قلعة لمات سمندره(Vr) بالحكم السلطاني وهو محدود معروف بحيث لا يحتاج إلي ذكر حدوده

(Y乏) نوقات: مركز لو اء في إيالة سيواس Sivas، وهي مركز الإيالة قبل عام •ب0 ام، يهبط من قلعتها

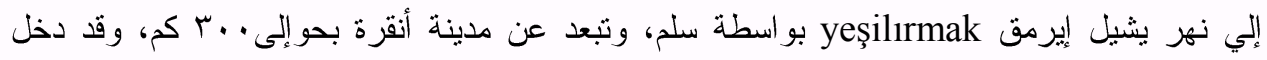
الإسلام المدينة بعد موقعة ملاذكرد، التي انتصر فيها المسلمون السلاجقة على الرئل الروم البيزنطيين

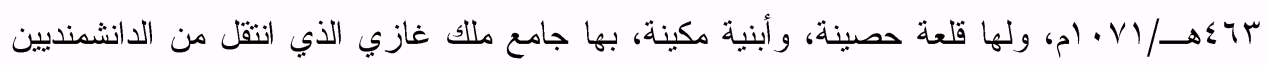

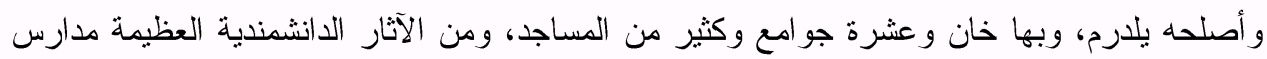

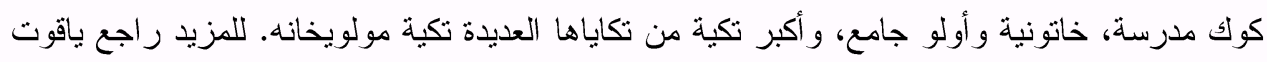

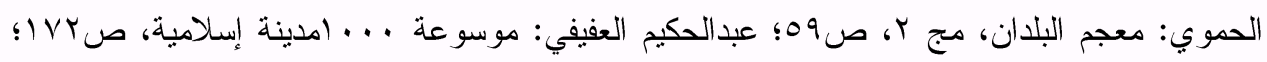

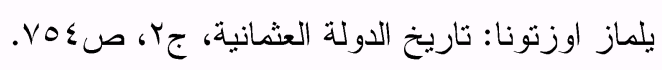

Ali Açkel: TOKAT, Ali Açıkel, islam ansiklopedisi, Ankara, cilt. 41, s. 219-223. (Vo) قلعة توقات: هي القلعة القديمة بها ثمانية وعشرين برجاً، بنيت أعلى قمة صخرية في وسط توقات.

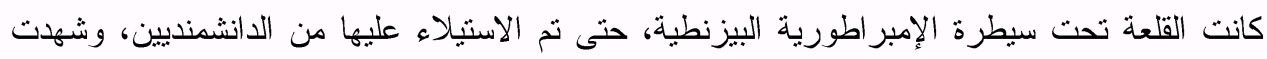

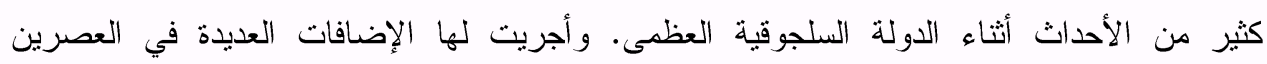

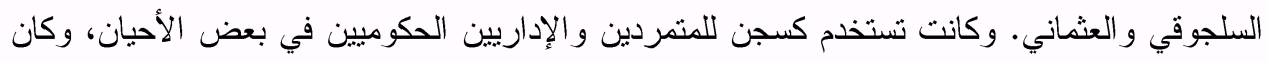
يطلق عليها أيضا الثجرة البرية. للتفاصيل يمكن الرجوع إلي: لئي https://en.wikipedia.org/wiki/Tokat_Castle

Ali Açkel: TOKAT, Ali Açıkel, cilt. 41, s. 219-223.

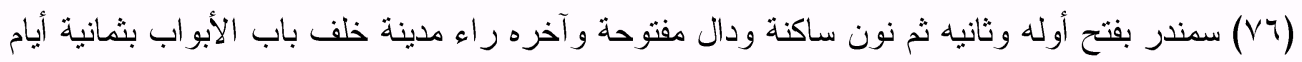

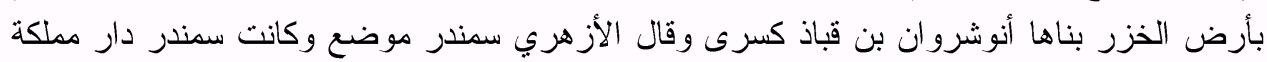

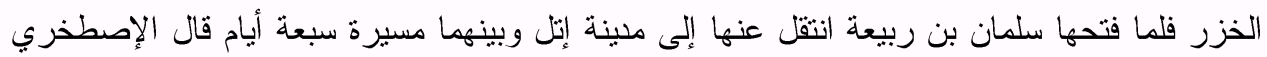

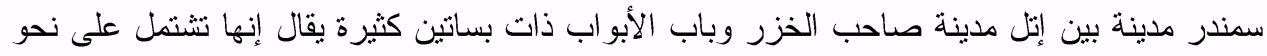

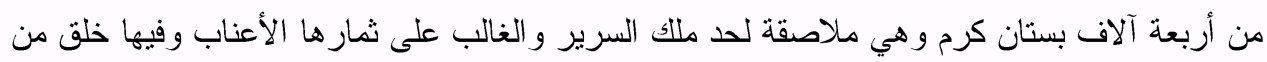


لإثتهاره في مكانه ومنها جميع قرية أغاثيوس المحدودة التي وقفها وشرط أن يكون جميع غلاتها ومحصولاتها لنفسه ما دام حياً وبعده يكون وقفاً لمصالح المدرسية.

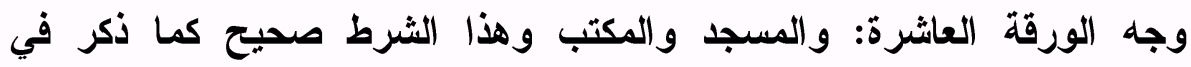

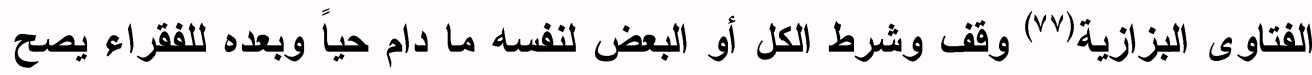

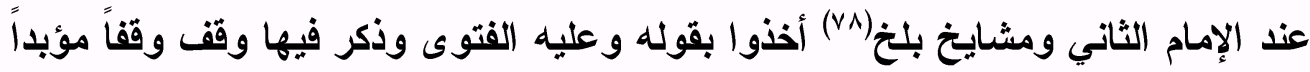

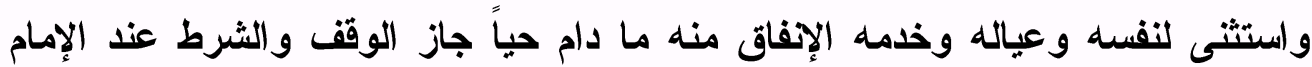

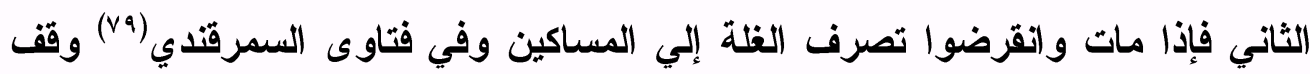

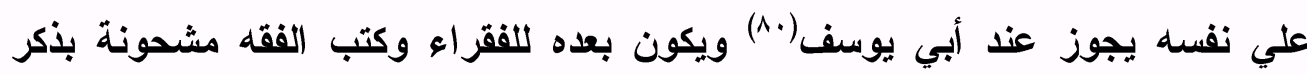

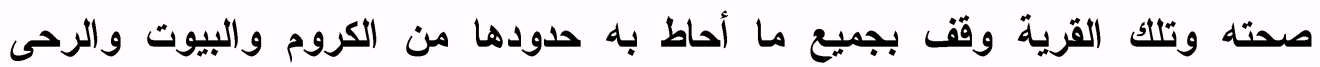

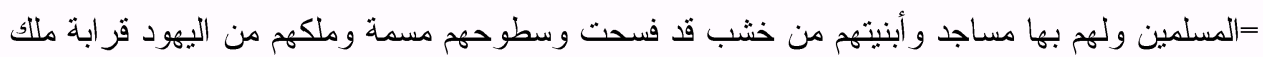
الخزر وبينهم وبين حد السرير فرسخان وبينهم وبين صاحب السرير هدنة ومن سمندر إلى إنل مدينة

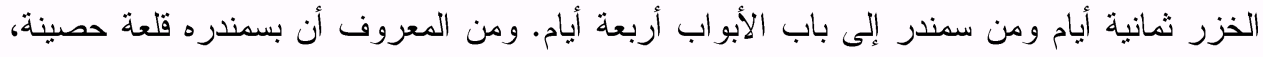

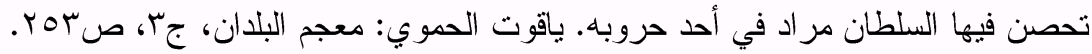
Revista Istorica: Dari De Sama, Documente si notite sup Conducerea lui. Iogra, Anulal 23-le 7-9 Julie- September 1937, s. 232.

(VV)

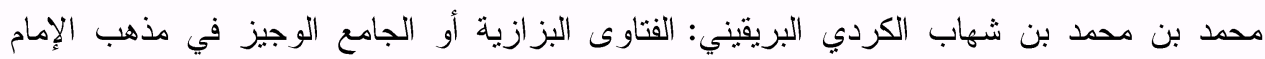

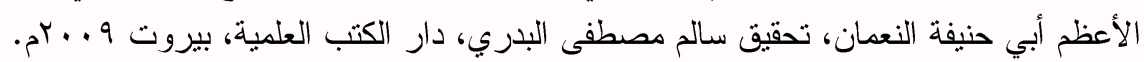
(VA)

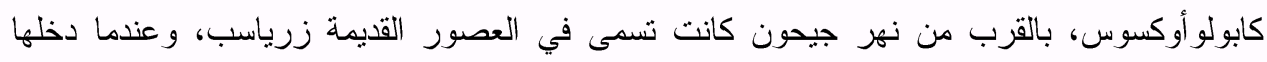

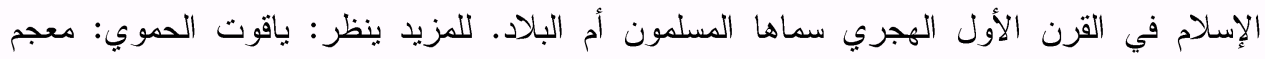

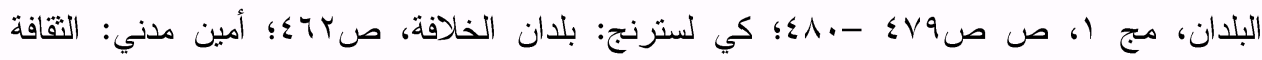

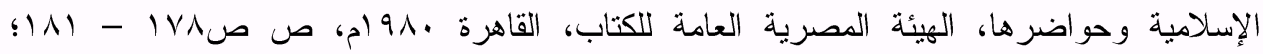

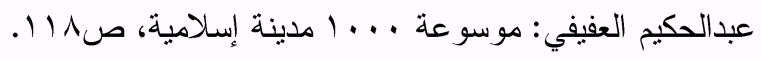

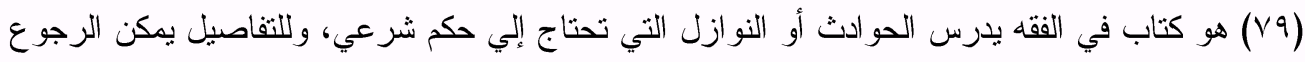

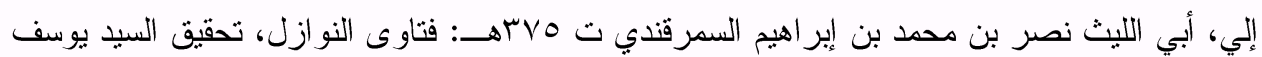

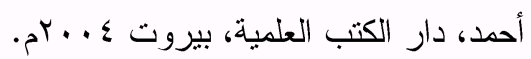
(^) هو يعقوب بن إبر اهيم الأنصاري المشهور بـأبي يوسف وهو من تلاميذ الإمام الأعظم أبي حنيفة

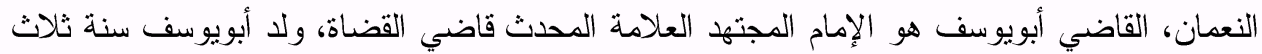
عشرة ومائة، وتفقه على أبي حنيفة، وأخذ الحديث، ونولى القضاء، ومنح لقب قاضي القضاة، نوفي في

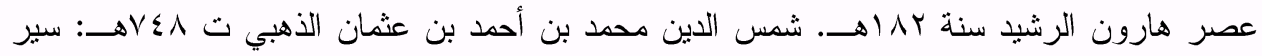

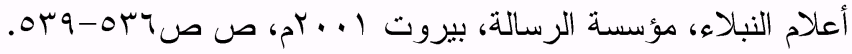


والمزارع والأراضي التي تتبت فيها النباتات الموسومة بجاير وهي كائنة في ناحية قسطنطينية وقربها مستغنية عن التحديد والتعريف لثهرتها في مكانها عند أهاليها. ظهر الورقة العاشرة: منتقلة إلي الواقف المذكور لا زال بالخير مذكوراً وسعيه

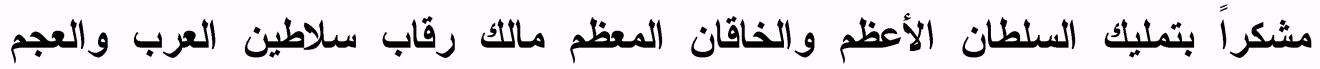
سلطان البرين والبحرين السلطان بن السلطان سلطان بايزيد خان بن سلطان محمد خان

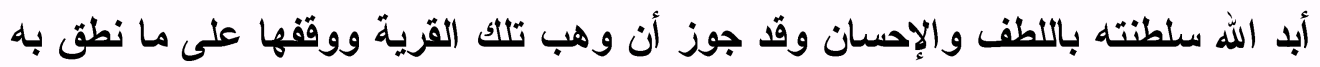

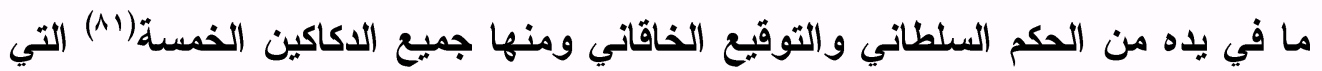
في قرب السر اجين في باطن محروسة قسطنطينية محدودة بحدودها الأربعة لا يحتاج إلي وني

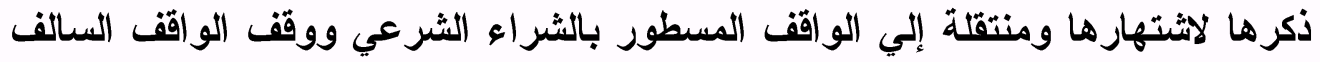
اسمه السامي تلثك القري ميع الحصص من القري والضياعات وغيرها والدكاكين

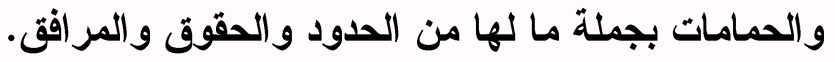

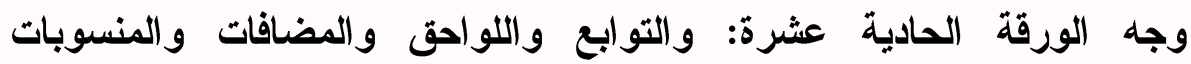

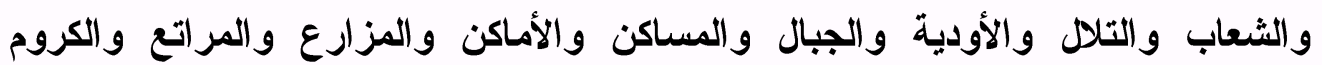

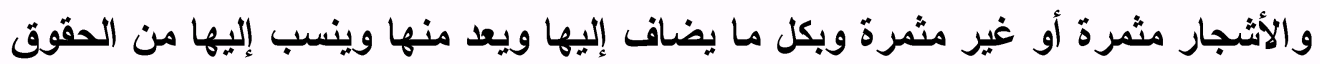

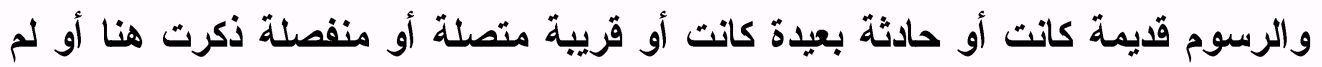

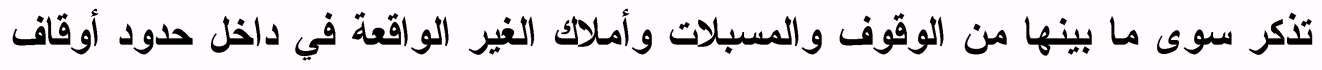

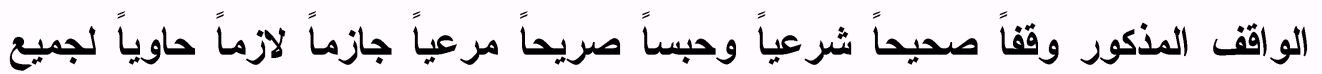

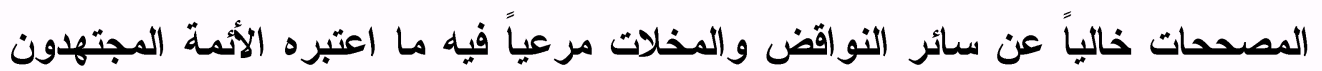

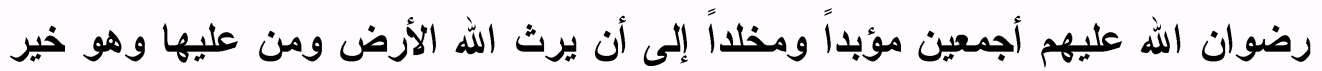
الوارثين لا يباع ولا يوهب ولا يرهن وله ولا يتلف. ظهر الورقة الحادية عشرة: بوجه من الوجوه وسبب من الأسباب فلا يحل ولألألأحد

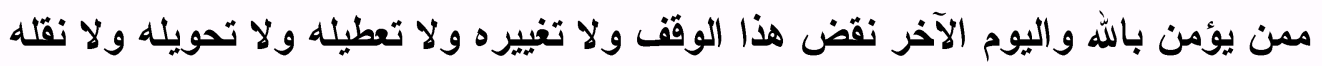

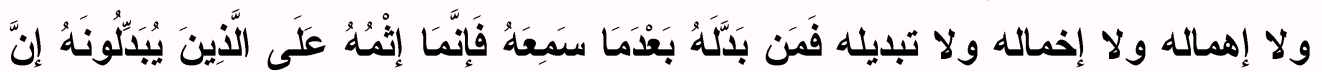

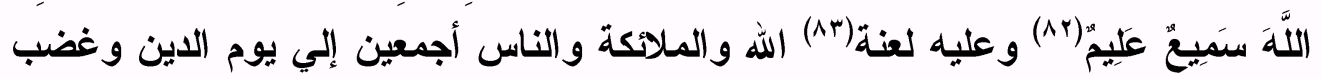


الله عليه ولعنه وأعد له(^) عذابًا أليماً يوم تجزى كل نفس بما كسبت لا ظلم اليوم إن الله سريع الحساب ثم شرط الواقف الواقف(ه) علي مثوبات خيراته والعارف الصارف دنياه إلي كسب حسناته التولية والنظر والتصرف في أمور جميع الأوقاف المذكورة آنفاً بأسرها وحذافيرها لنفسه النفيسة ما دام روحه أنيسة فسح الله تعالي مدة حياته(^م) بحيث يتصرف فيها كيف يشاء من استبدال وغيره وبعده صانه الله تعالي. وجه الورقة الثانية عثرة: عن الآقات والبليات لأصلح عتقائه المهتدين ثم لأصلح أبنائهم وأبناء أبناءهم ثم فثم ما توالدوا وتناسلوا بطناً بعد بطن وقرناً بعد قرن فإذا انقرضوا ولم يبق منهم أحد والباقي هو الله الأحد يكون أمر التولية والنظارة على ما يراه الشرع القويم والدين المستقيم وشرط الواقف على كل من يتولى وينظر في أمر الأوقاف أن بستغلها بأنفع أنواع الاستغلال ويجد بالسعي الجمبل في استثمارها علي وجه الحلال ويجمع كل غلاتها ويضبط جل ارتفاعاتها ويجدد الوثائق والحجج الدالة عليها إن احتيج إلبها فما رزقه الله تعالي يصرفه أولاً إلى عمارة الوقف وإصلاحه عند ظهور الخلل وفساده وبعد الاستغناء عنها يصرفه إلى إصلاح المدرسة المشار إليها ومرمتها أن أحتيج إلبها وكذا إلى تعميز المسجد والمكتب المذكورين فما فضل من الرقبة. ظهر الورقة الثانية عثرة: يصرف عُثر محصولات الأوقاف بالغاً ما بلغ إلى هـ جهة معيشة نفسه بشرط أن يكون عليه خدمة كتابة المسجد المسفور وجباية قرية أغاثيوس المزبورة وجباية الحمام الذي في قلعة سمندره وجباية الحمام الذي في محروسة توقات وجميع الاكاكين ويكون عليه المبط المصولات

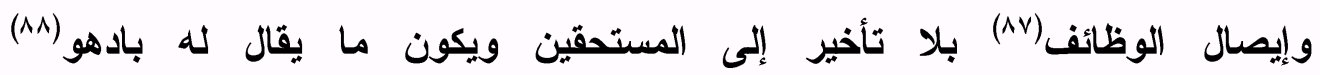

$$
\begin{aligned}
& \text { (^乞) أخطأ الخطاط وكتبها بالشكل الإملائي و أعده. }
\end{aligned}
$$

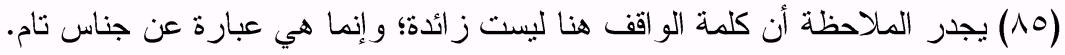

$$
\begin{aligned}
& \text { (AT) كتبها الخطاط بالثكل الإملائي حيوته. }
\end{aligned}
$$

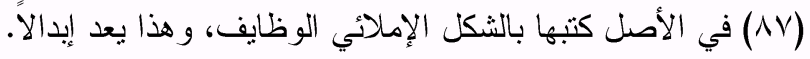

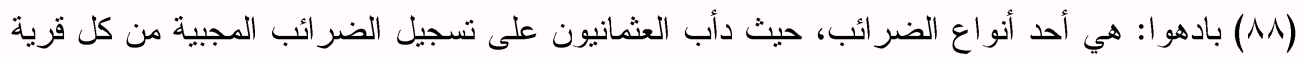
ومدينة حسب الألوية في دفاتر خاصة. كانت اللغة المستعملة في هذه الدفاتر هي اللغة العثمانية المليئة

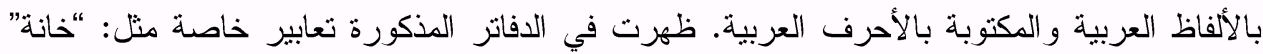

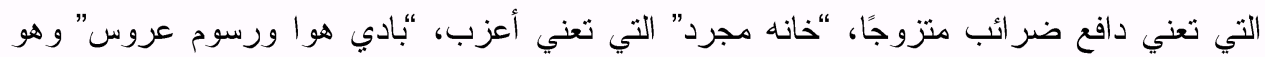

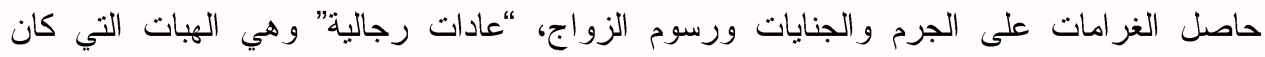

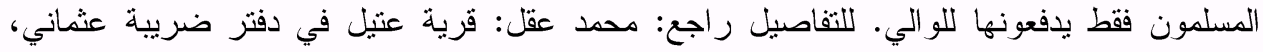
http://webcache.googleusercontent.com 
للمتولي(^9) ولجابي(·9) القرى الموقوفة سواء أدى تلك الخدمات بنفسه أو بشخص آخر

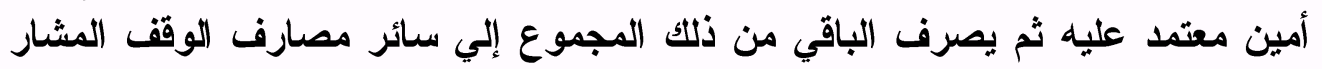

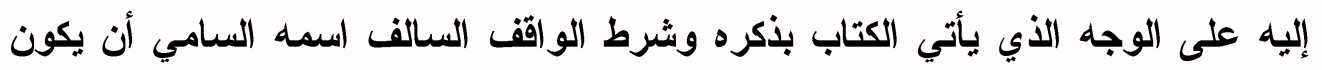

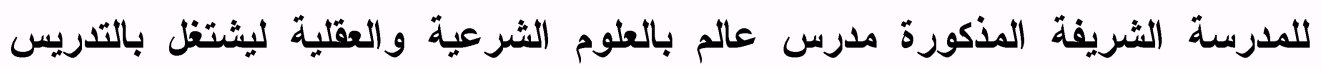
و و إفادة العلوم المذكورة.

وجه الورقة الثالثة عشرة: وتعليمها كل يوم سوى أيام جرت العادة بالتعطيل فيها وعُين له كل يوم عشرين درهماً وشرط الواقف المشار إليه أفاض الله سجال لطفه عليه عليه

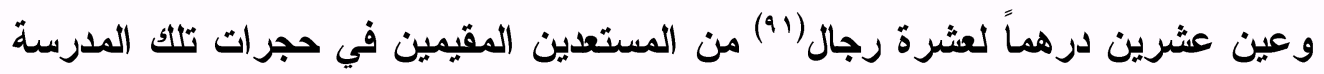
التي عددها عثرة لكل واحد منهم في كل يوم درهمان وشرط أن يسكن في تلكئ المدرسة

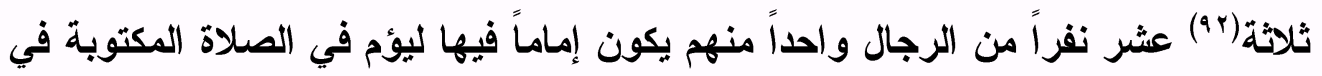

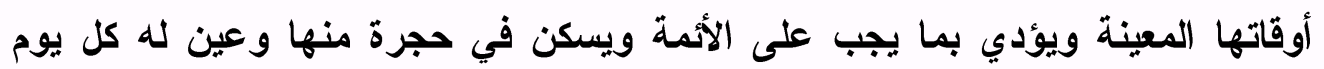

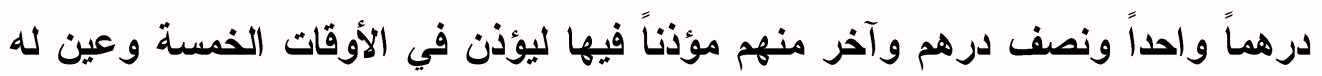

(9) الو لاية بمعناها العام في الثرع: تتفيذ القول على الغير، شاء الغير أو أبى، هي حق قرره الثرع

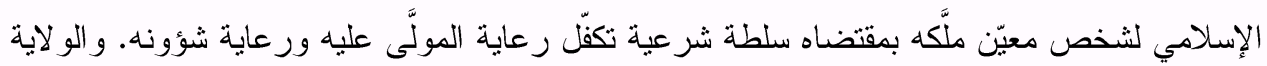

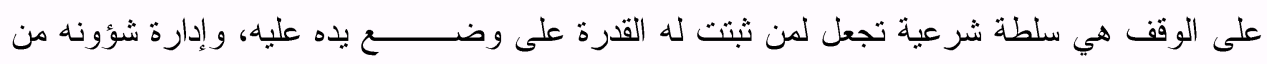

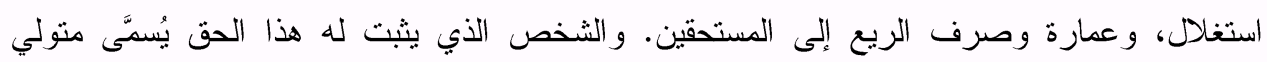

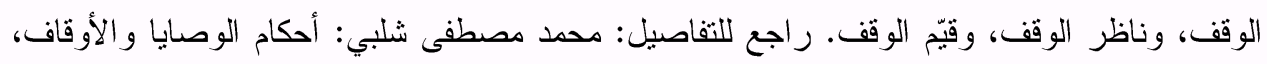

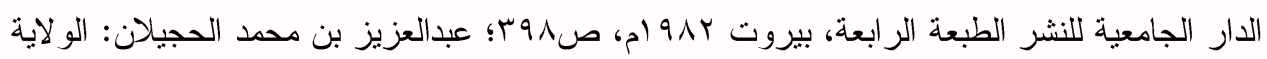

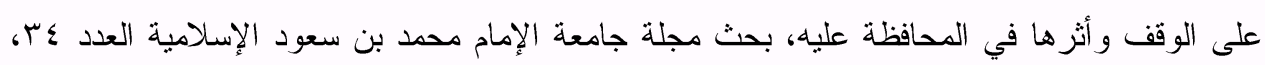

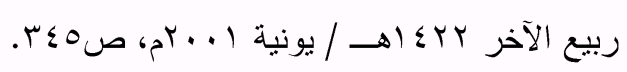

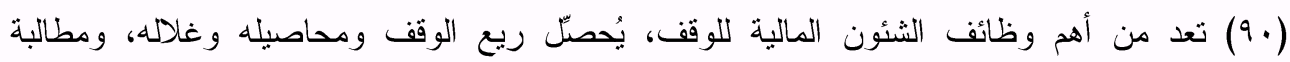
مستأجري الوقوفات، وتسليم ريع الوقف للناظر، وهو من يجمع الماء للإبل، وهو محصل ورادات

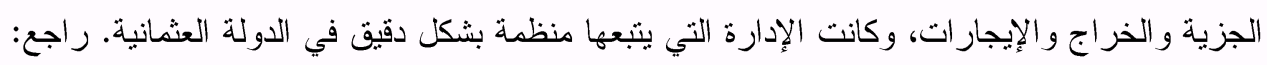
محمد عفيفي: الأوقاف و الحياة الافتصادية في مصر في العصر العثماني، الهيئة المصرية العامة للكتاب، القاهرة او9 (م، صه 9؛ أنور محمود زناتي: معجم مصطلحات التاريخ و الحضارة الإسلامية،

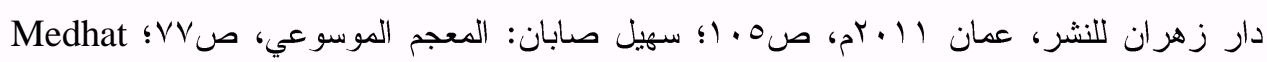

Sertoglu: Osmanlı Tarih Lügat1, Istanbul 1986, s.60.

(91) (91) أخطأ الخطاط وكتبها بالشكل الإملائي رجل. (r) في الأصل كتبها بالثكل الإملائي تلثنة. 
كل يوم درهماً واحداً ثم الآخر منهم بواباً وفراشاً فيها ليشتغل بكنسها وإغلاق بابها وفتحه وسائر ما يتعلق بها من الخدمات ويسكن مع المؤذن في حجرة.

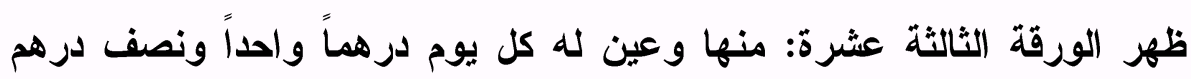

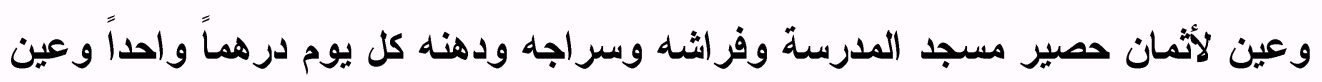
الواقف لإيجار (ra) أرض المدرسة في كل سنة من شحم بالمن المعمول به في القصبة

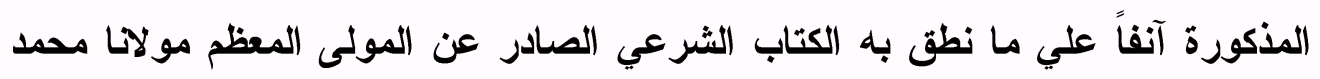

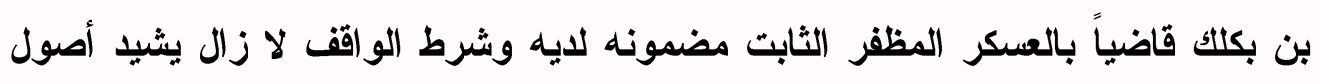
الخيرات ويسدد مباني المبرات أن يكون للمسجد الأي بناه في محروسة قسطنطينية في جنب الوضع الموسوم بآت ميداني إمام صالح متشرع متورع تقي نقي يؤم فيه لمن يأتم

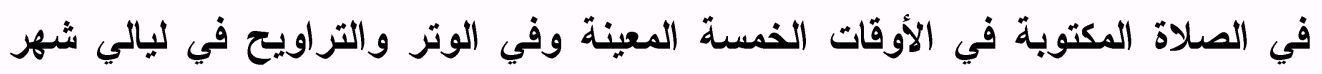

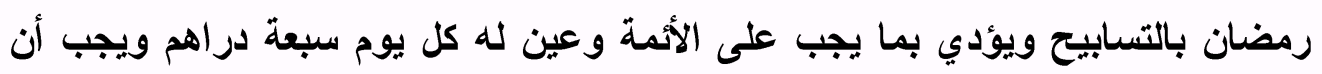
يكون.

وجه الورقة الرابعة عشرة: ذلك الإمام ممن يصلح أن يكون مقتدى للأنام من

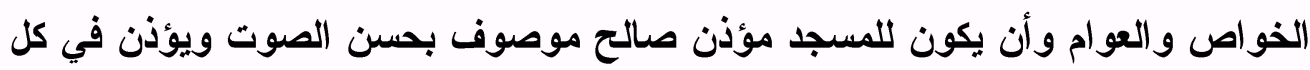

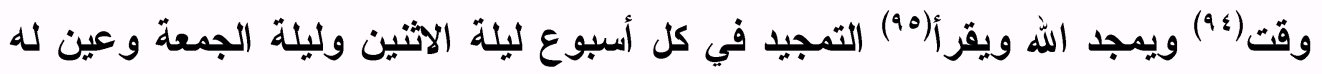

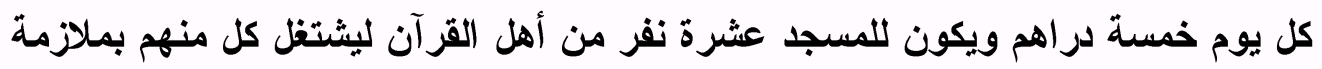

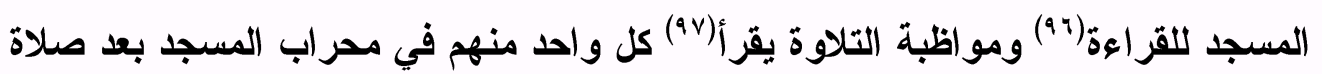

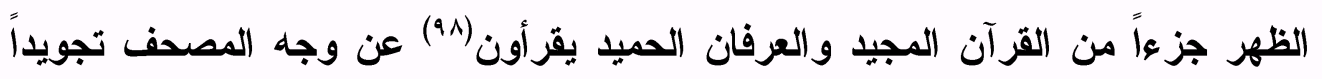

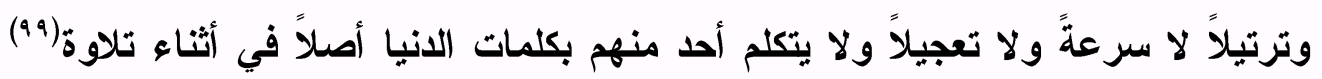
القرآن حتى يتم علي وجه الكمال ويفرغ كل منهم عن القراعة بلأل بالتعظيم والإجلال

$$
\begin{aligned}
& \text { (19) في الأصل بالثكل الإملاثئ لإجارة وهي مصطلح فقهي. }
\end{aligned}
$$

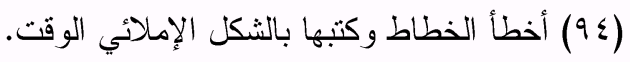

$$
\begin{aligned}
& \text { (90) أخطأ الخطاط وكتبها بالثكل الإملائي ويقر اء. } \\
& \text { (97) أخطأ الخطاط وكتبها بالثكل الإملائي للقر اة. } \\
& \text { (9) (9Y) أخطأ الخطاط وكتبها بالثكل الإملائي يقر اء. } \\
& \text { (91) أخطأ الخطاط وكتبها بالشكل الإملانئي يقرؤن. } \\
& \text { (99) في الأصل كتبها بالثكل الإملائي تلاوت. }
\end{aligned}
$$


ويدعو (..) للواقف بالتضرع والابتهال ويكون الواحد منهم رئيساً أحسن الأصوات عالماً بوجوه القراءات(1 +1) وعين لرئيسهم المعروف بسر محفل كل يوم درهمين. ظهز الورقة الرابعة عشرة: ولكل واحد من التسعة الباقية كل يوم درهماً واحداً

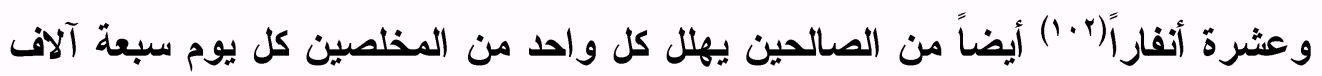

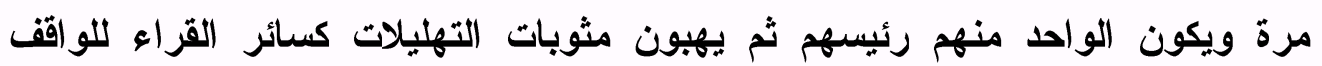

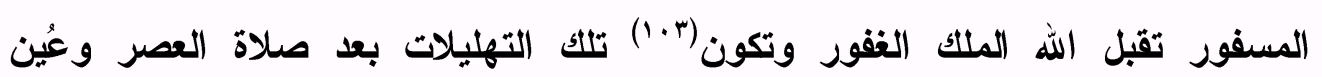
لرئيسهم كل يوم درهماً واحداً ونصف درهم لكل واحد من التسعة الباقية كل يوم درهماً

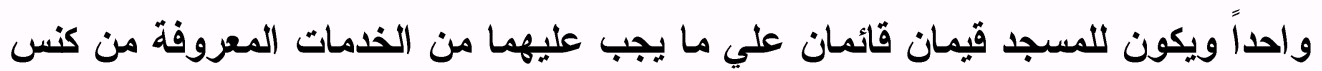

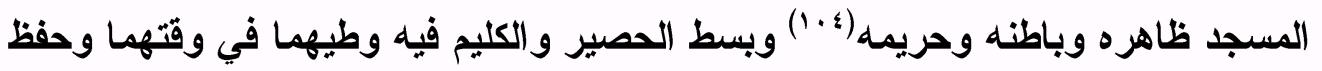

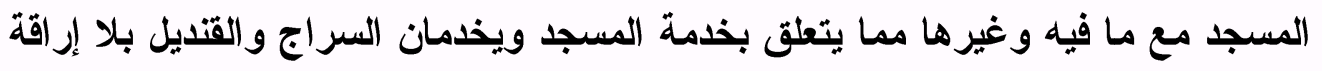
الاهن علي الحصير والمنديل يوقدان ويطقئان في وقتهما ويكون خدمتهما بطريقة المناوبة وعين لهما أربعة.

وجه الورقة الخامسة عشرة: دراهم لكل منها اثنان وعين لأثمان حصير المسجد

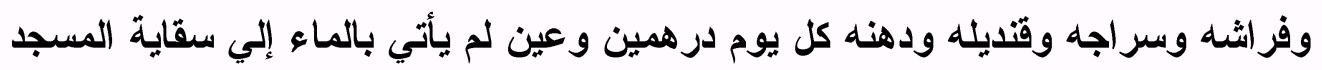

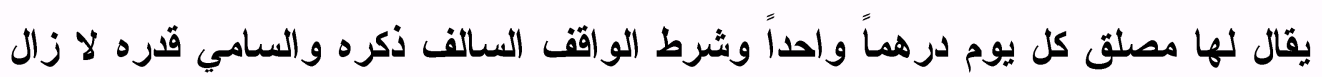

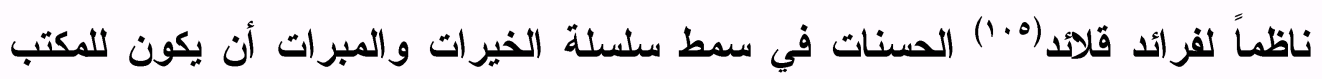
المذكور معلم متشرع متورع تقي نقي قادر علي التجويد والترتيل ساعياً في التعليم

( ) (1) أخطأ الخطاط وكتبها بالثكل الإملائي يدعو ا.

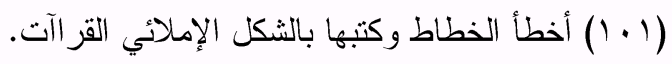

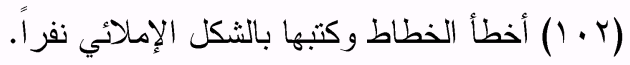

( ( - (1) أخطأ الخطاط وكتبها بالثكل الإملائي ويكون.

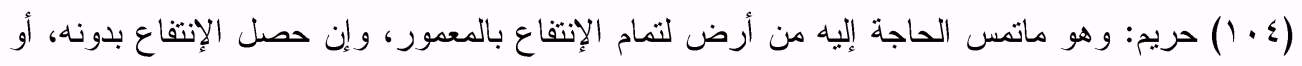

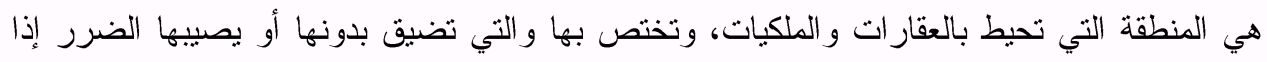

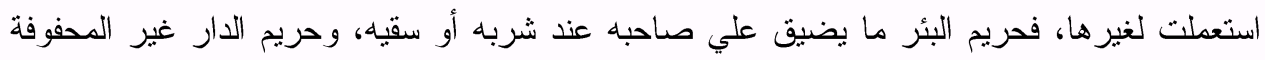

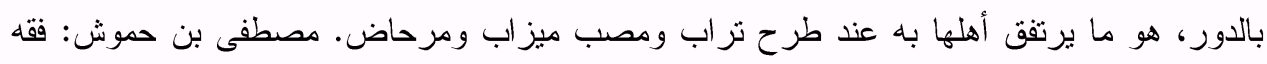

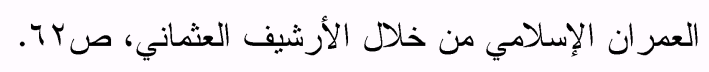

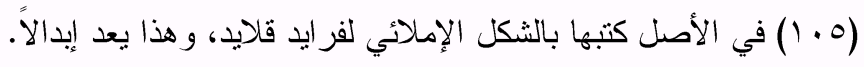


و التكميل كاملاً في القراعة فائقاً (1) فيما بين الأقران بشتغل كل يوم سوى يوم الجمعة

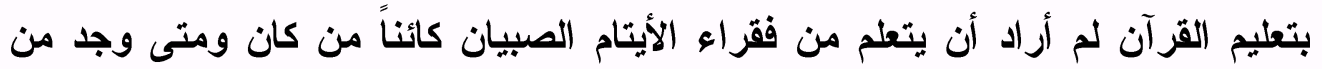
أيتام عتقاء الواقف يأخذه ويؤدبه ويعلمه وان لم يوجد منهم يأخذ من أيتام سائر الناس أنس

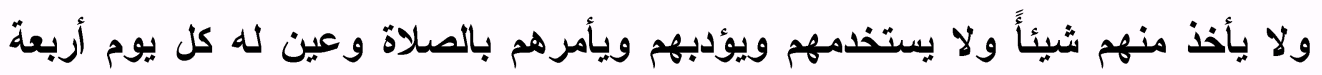

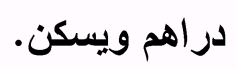

ظهر الورقة الخامسة عشرة: في ذلك المكتب الثريف أربعة نفر من الأيتام

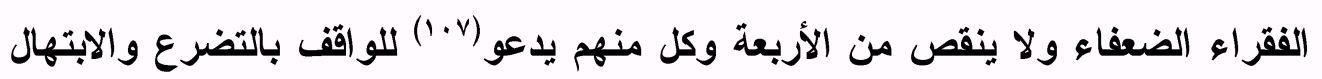

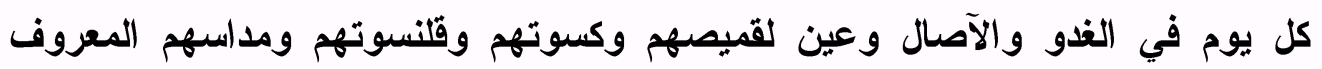

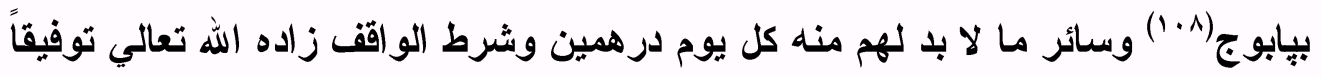
في اقتناء الحسنات واقتناص الصدقات الباقيات الصالحات أن يكون كل من يكون قاضياً

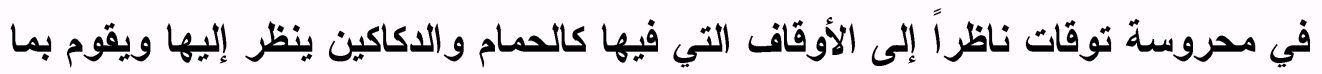

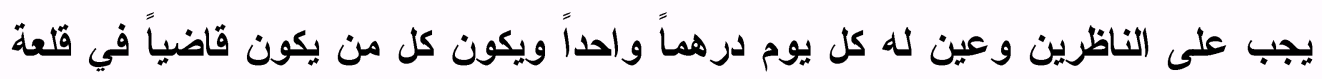

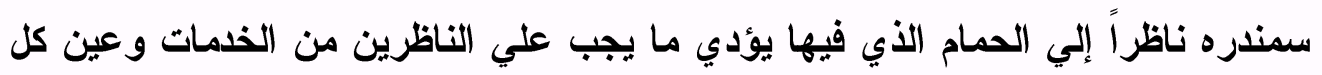

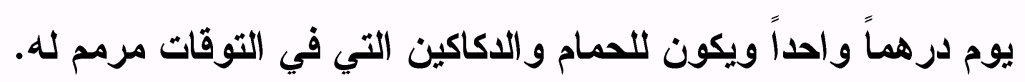

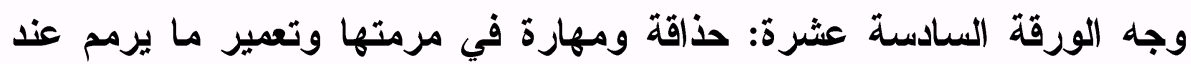

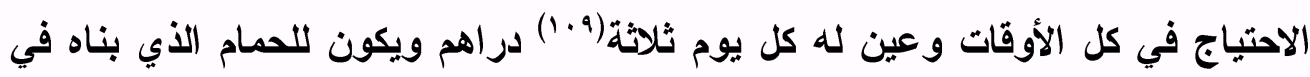

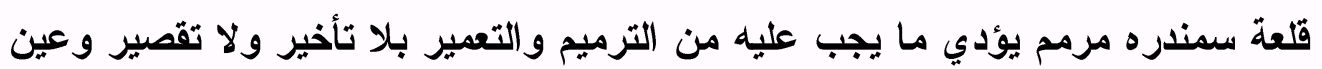

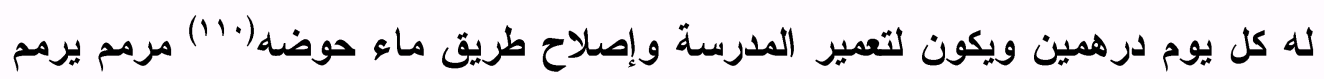
بالتثديد والإحكام والسداد عند ظهور الخلل وطرق الفساد وعين له كل يوم درهمين ولهين

\footnotetext{
(7 1 ) أخطأ الخطاط وكتبها بالثكل الإملائي القراة فايقاً.

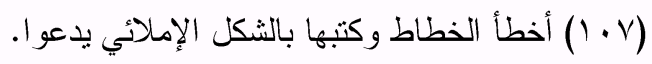

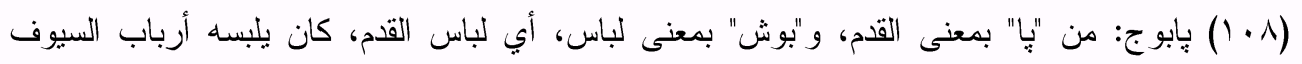

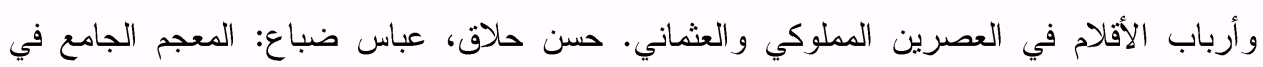

المصطلحات الأيوبية و المملوكية و العثمانية ذات الأصول العربية و الفارسية و التركية، بيروت 999 ام، وبن

ص ص اسד- יזי

(9 ( ) في الأصل كتبها بالشكل الإملائي ثلثة.

(1) أخطأ الخطاط وكتبها بالثكل الإملائي حوزه. 
ويكون للمسجد والدكاكين التي في قسطنطينية مرمم يرمم بلا إهمال ولا تأخير ولا إمهال وعين له كل يوم درهمين وعين لرقبات جميع الأوقاف كل يوم اثنين وثثلاثين ('1') درهماً ويكون لضبط محصولات القري التي في اماسيه حميت عن القلوب القاسية جابي موصوف بالأمانة والديانة معرضاً عن إيذاء أحد والأخذ بغير حق وعن الإهانة والئ والخيانة

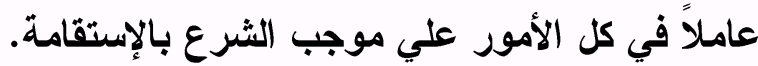

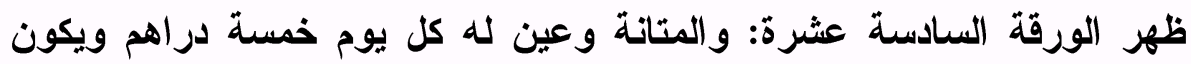

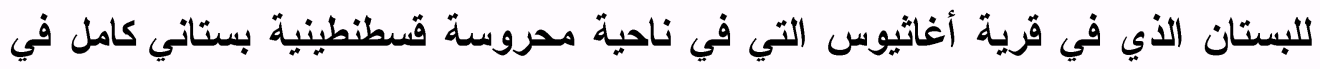

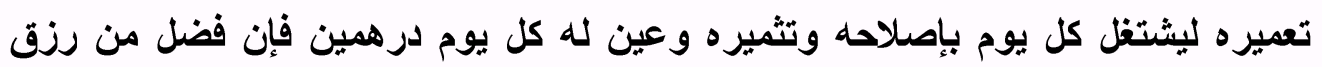

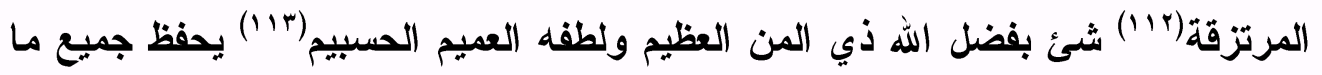

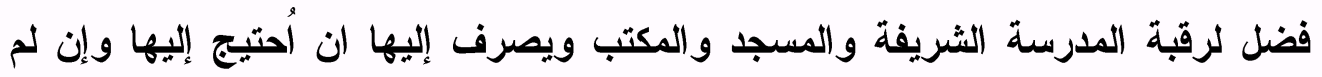

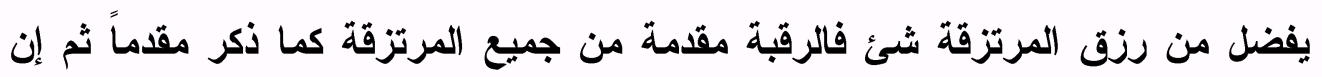

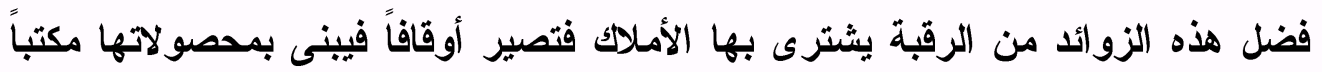

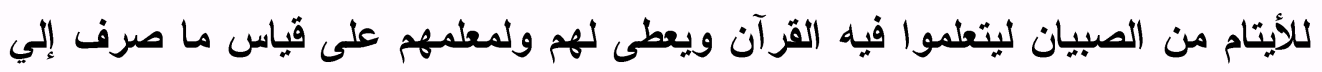
المكتب السابق وشرط الواقف أن الزوائد تصرف إلي مواضع الخع الخيرات.

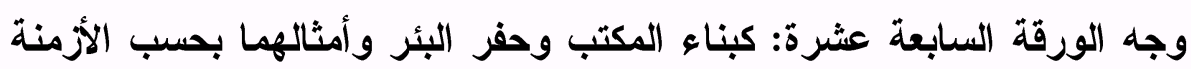

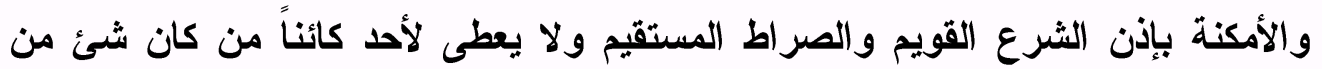
زوائد الأوقاف فلو فعلوا فعليهم الآثام وهي على آخذيها حرام يسئلون عنها يوم الجزاء

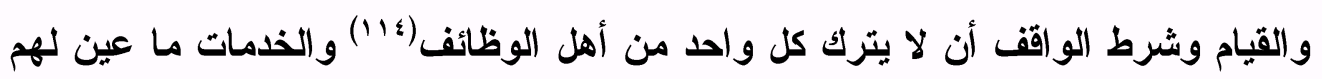
ووجب عليهم في الخدمات إلا لمانع شرعي وعذر قوي مرعي وحيئ ينصب النائب عن

(111) (111) أخطأ الخطاط وكتبها بالثكل الإملائي اثثين وثلثنن.

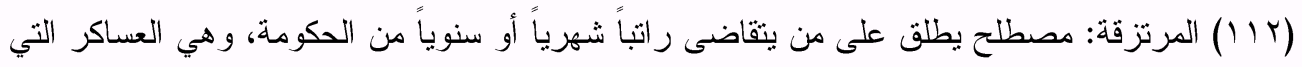

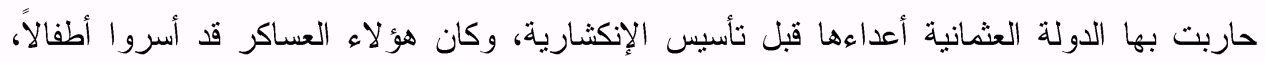

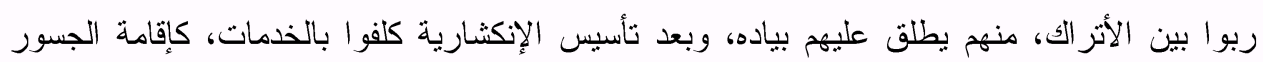

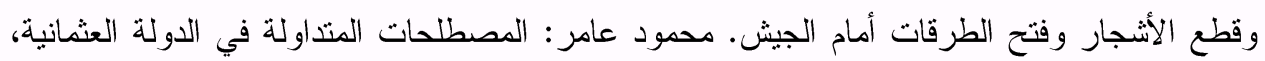

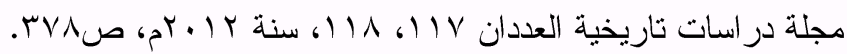

$$
\begin{aligned}
& \text { (1) (1) وردت هذه الكلمة هكذا بالنص، وتجدر الإثارة إلي أنها تكتب في التركية هكذا. }
\end{aligned}
$$

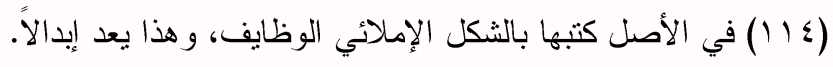


نفسه إن أمكن لئلا يفوت تلك الخدمة ويكون كل واحد منهر موصوفاً بالديانة والأمانة

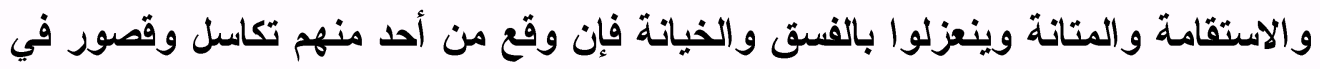
خدمته ينصحه المتولي ولو عاد ثانياً يعاتبه وإن استمر عليه يعزله إن قدر على عزله بله وألا يعرضه (110).

ظهر الورقة السابعة عشرة: علي السلطان في ذلك الزمان ولا يعزل واحد منهم

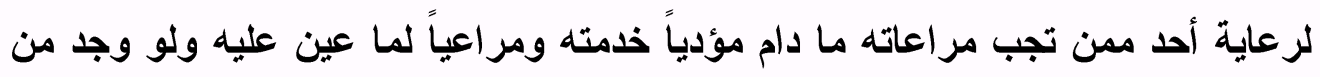

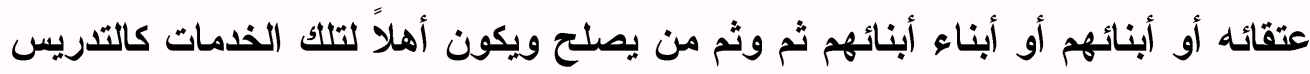

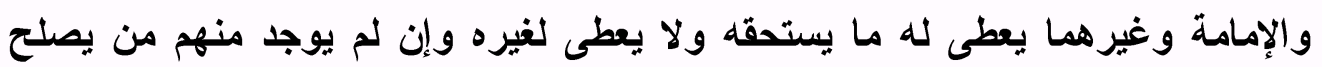

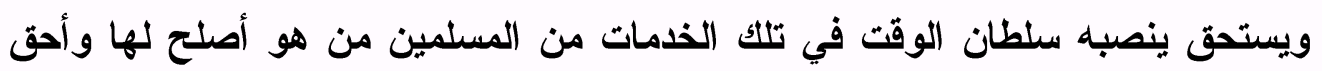
وعلى هذا يراعى ويحفظ هذا الثرط في كل حين من الأحيان إلي انقراض الدهور

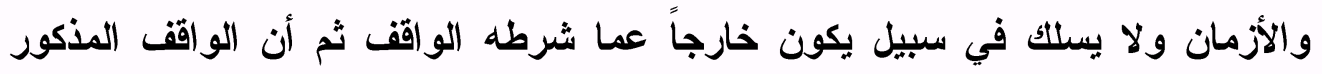
بعدما وقف على الوجه المشروح والنهج المشروع تلك الأوقاف جعل الله تعالي حسنات التهات كل حبة منها مثل أحد أوقاف نصب عتيقه صوفي حضر بن عبدالله متولياً.

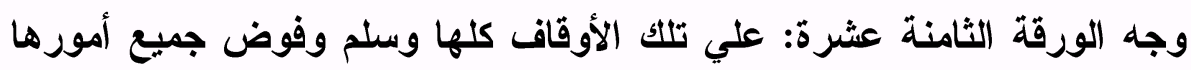
إلي معظم آرائه وجلها فباشر إلى خدمة الأوقاف بالسداد وتصرف فيها كما هو المر اد ثم

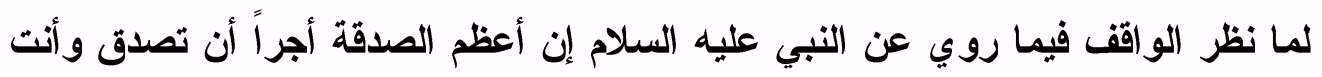
صحيح وتفكر في أن الوقف خراب إذ كثيراً ما يقع في يد الخسيس الثحيح أراد صرفها إنها

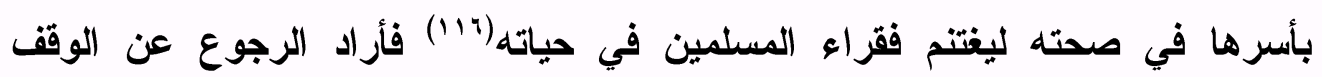

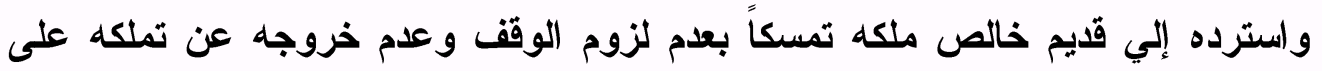

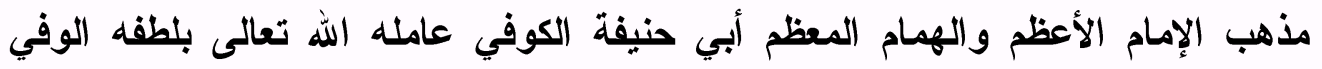

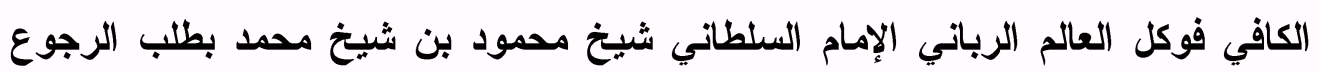
عن وقفه الذي ليس بالتسجيل بمؤكد فبعدما ثبت وكالة الوكيل المذكور وتحقى تولية المتولي المسفور رافعاً.

$$
\begin{aligned}
& \text { (110) أخطأ الخطاط وكتبها بالشكل الإملائي و آلا يعرضه. } \\
& \text { (1) (1) في الأصل بالثكل الإملائي حيوته، وهي كتابة مصحفية. } \\
& \text { - r人. - }
\end{aligned}
$$


ظهر الورقة الثامنة عشرة: هذا الأمر إلى مولى الموالي العظام أعلى الأعالي

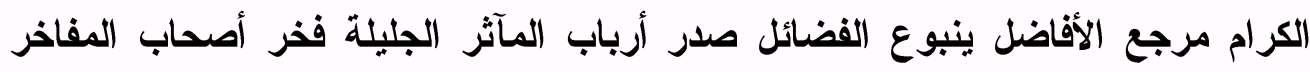
العلية الحاكم الموقع على الكتاب المتوقع رضاء رب الأرباب مولانا علاء الدين بن

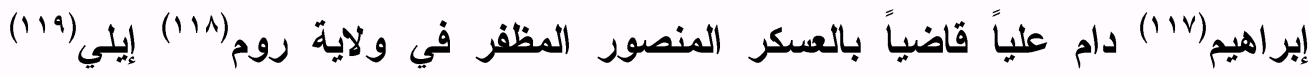

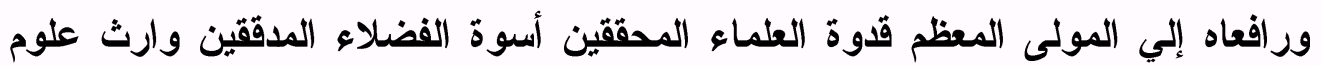
الأنبياء والمرسلين المخصوص بعناية رب السموات والأرضين الحاكم الموقع أعلاه

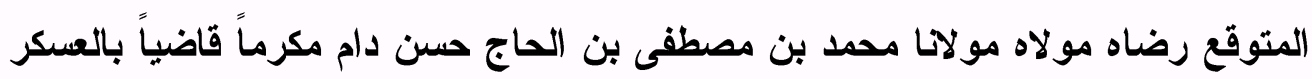

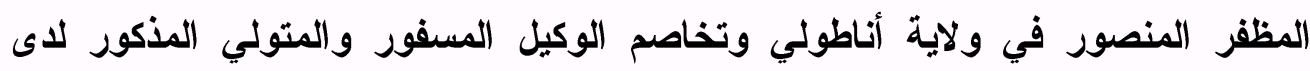

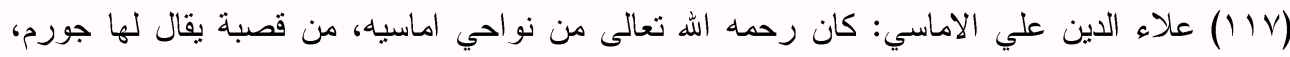

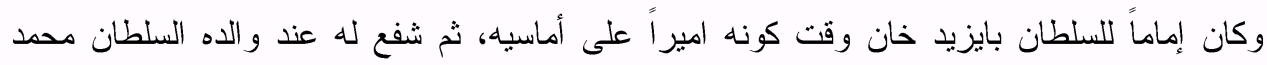
خان، فأعطاه مدرسة كومش في نواحي اماسيه، بعد نوقف كثير ولما جلس السلطان بايزيدخان على إنى سرير السلطنة، اعطاه قضاء انقره وضم اليه المدرسة البيضاء بالمدينة المزبورة، ثم اعطاه قضاء بروسه، ثم ارسله رسولا من جهته إلى سلطان مصر قايتبابي واصلح بينهما، ثم جاء إلى قسطنطينية فأعطاه السلطان بايزيدخان قضاء العسكر بو لاية اناطولي، و وزل عنه في سنة سبع وتسعمائة، و وعين لله

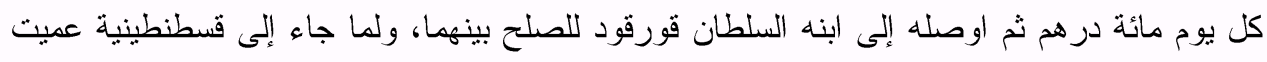

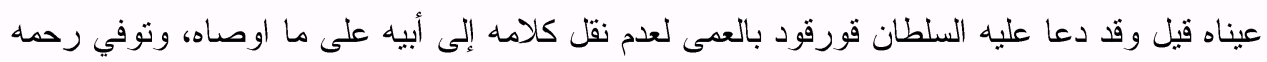
الله تعالى في سنة سبع و عشرين وتسعمائة كان طليق اللسان جريء الجنان محبا للخيرات ور اغبا في

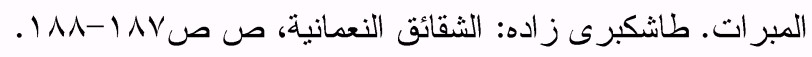
(1) روملي: هي أحد الإيالات العثمانية و التى تأسست عام بآبام، كإيالة ثانية بعد إيالة أناضولي،

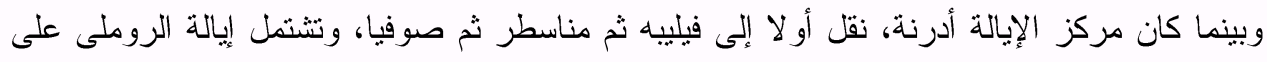

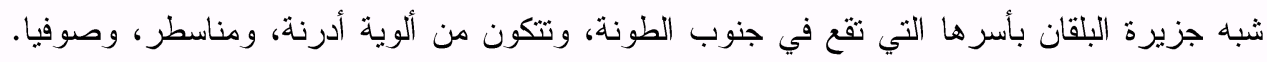

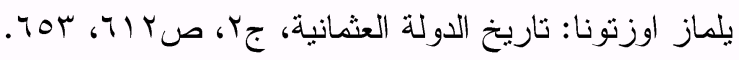

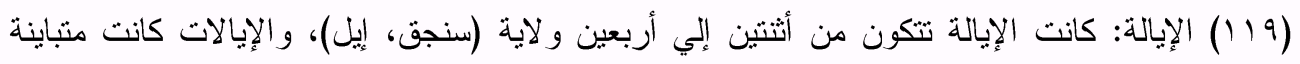
بصورة كبيرة، وكان علي رأس كل ولاية وال عسكري يطلق عليه اسم سنجق بك، وهذه اللفظة في الوقت نفسه رتبة لو اء بحري، ومنحت رتبة بكلربك إلي و لاة الألوية (سنجق) الكبيرة، وهؤلاء سموا

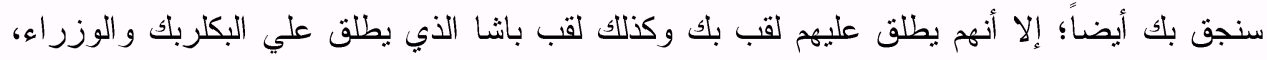
كانت الألوية تقسم إلي أقضية (إيلجه)، وكان لكل قضاء عدة نواحي، و الناحية تعادل بوجاق، وكانت

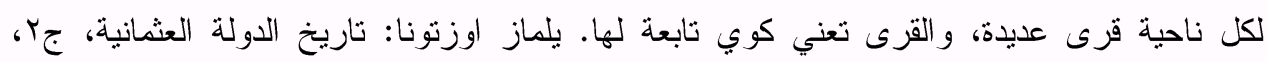


الحاكمين المزبورين فحكما حال نفاذ أحكامهما في محل ولايتهما بصحة ذلك الوقف ولزومه علي وجه الوكيل المومي إلبه. وجه الورقة التاسعة عشرة: على مذهب من يزى لزوم الوقف والفتوى عليه أشهدا به مولانا أحمد بن قرجه والحاج نصوح بن عبدالله والحاج مصطفي بن عبدالله

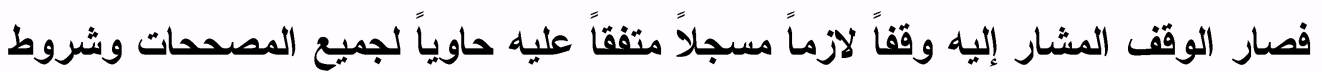

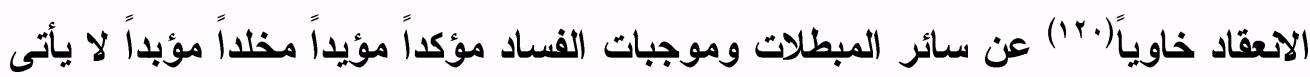
عليه زمان إلا أحكمه ولا حين وآن إلا أبرمه ولا أوان إلا ألزمه لا يباع ولا يوهب ولا

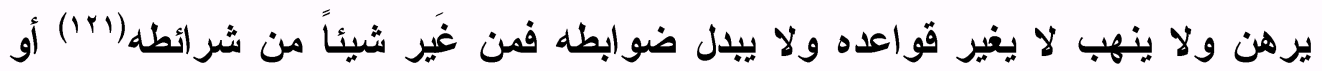
قانوناً من ضوابطه وسعى في إبطاله وتبديله وقصد في نسخه وتحويله بتأويل فاسد وتوجيه كاسد فقد التزم المحرم واستوجب المأثث وارتكب أكبر المعاصي فيجزى يوم يؤخذ بالنو اصي والله حسيبه والمالك طليبه والزبانية رقيبه والنار نصيبه وعليه لعنة الله. ظهر الورقة التاسعة عشرة: والملائكه والناس أجمعين خالدين فيها لا يخفف

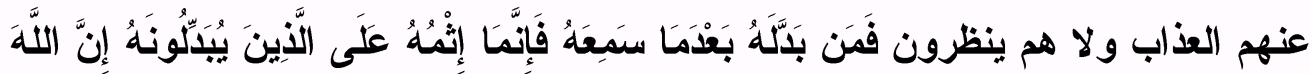

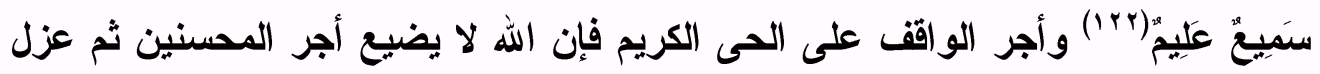
الواقف المومي إليه ذلك المتوكل لكون التصرف أمر ذلك الوقف بيده ما دام حياً وقد وقع الفراغ في تحريز هذه الحجة الشريفة الشرعية والوثيقة المرعية الدينية بإعانة من العنايات بأنواع الاحترامات الربانية والهاية الرحمانية فى أوائل شهر محرم الحرام وقد وقع تاريخها بفتوحات يوم عاشور واقفة عاش نورا من شهور سنة سبع وتسعين وثمان مائة وعلى جميع ذلاك وقع ما لا بـ له فى الحكم والإشهاد لينسد به طرق الظلم والعناد والفساد جعنا الله تعالى وإياكم من أهل الرشاد والسداد إنه لطيف بالعباد رؤوف(rri) جواد.

وجه الورقة العثرين: شهود الحكم والتسجيل مولاتا أحمد بن قرجه والحاج نصوح بن عبدالله والحاج مصطقى بن عبدالله. ما نهى في هذا السفر الثرعي في الوقف

$$
\begin{aligned}
& \text { (Y. ( ) في الأصل كتبها بالشكل الإملائي حاوياً. }
\end{aligned}
$$

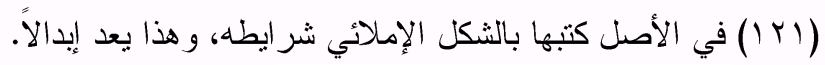

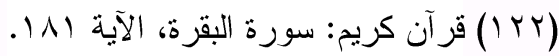

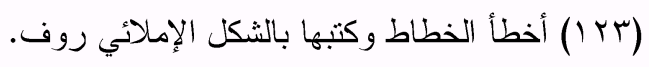




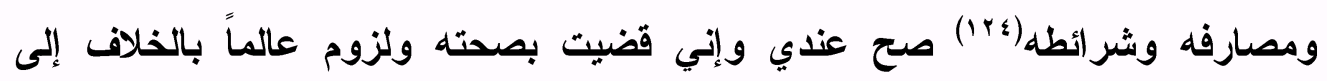

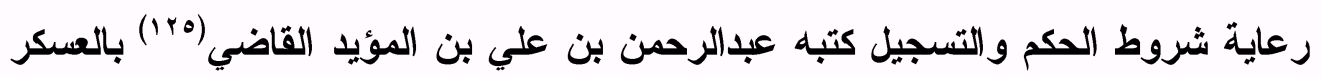

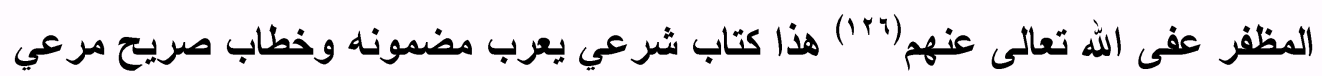

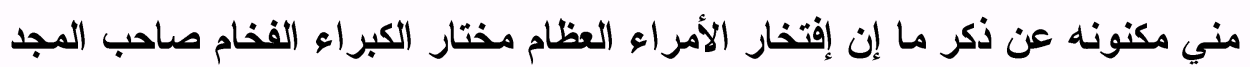

(1) ( ) في الأصل كتبها بالشكل الإملائي وشر ايطه، وهذا يعد إبدالاً.

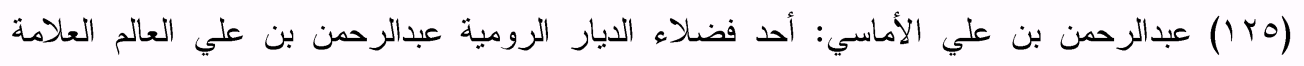
المحقق الفهامة، المولى عبدالرحمن بن المؤيد الأماسي الرومي الحنفي، ولا بأماسية في صفر سنة سنين وثمانمائة و اشتغل في العلم ببلده ولما بلغ سن الشباب صحب السلطان أبا يزيد خان حين كان أميراً بأماسية فوشى به المفسدون إلى السلطان محمد خان و الد السلطان أبي بزيد فأمر بقتله فبلغ السلطان أبا بان

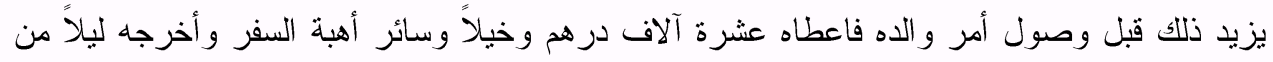
أماسية ووجهه إلى بلاد حلب وكانت إذ ذاك في أيد الجر اكسة فذخلها سنة ثمان وثمانين وثمانمائة فأقام هناك مدة و اشتغل بها في النحو فقرأ على بعض أهلها في المفصل ثم أثار عليه بعض تجار العجم أن يذهب إلى المولى جلال الدين الدواني ببلدة شيراز ووصف له بعض فضائله فخرج مع تجار العجم في بلدي تللك السنة وقصد المنلا المذكور فقر أ عليه زماناً كثير أوحصل عنده من العلوم العقلية و العربية و التفسير و الحديث و أجازه وشهد له بالفضل التام بعد أن أقام عنده سبع سنين فلما بلغه جلوس السلطان أبي يزيد

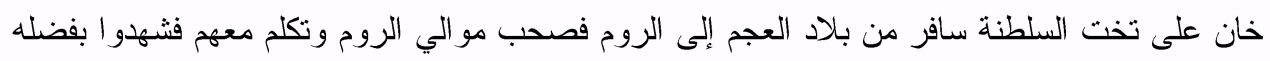
و عرضوه على السلطان فأعطاه مدرسة قلندر خانه بالقسطنطينية ثم إحدى الثماني ثم قضاء القسطنطينية ثم أدرنة ث قضاء العسكر بو لاية أناطولي ثم بولاية روم إيلي ثم عزل وجرت له محنة ثم لما تولى فيلى

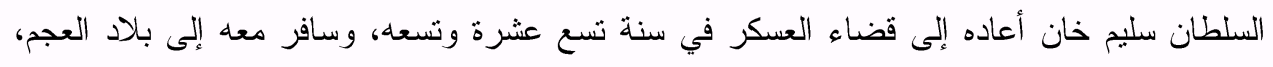
وكان معه في محاربة الثاه إسماعيل، ثم عزل عن قضاء العسكر بسبب اختلال حصل له في عقله في

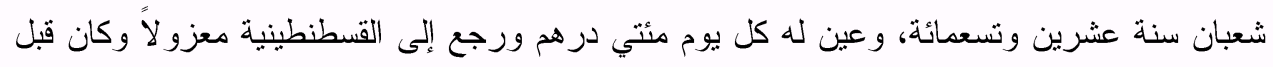
اختلاله بالغاً الغاية القصوى في العلوم العقلية و العربية ماهراً في التفسير مهيباً حسن الخط جداً ينظم الشعر بالفارسية و العربية وله مؤلفات بقي أكثر ها في المسودات منها رسالة لطيفة في المو اضع المشكلة من علم الكلام وكانت وفاته بالقسطنطينية ليلة الجمعة خامس عشر شعبان سنة اثتنين وعشرين

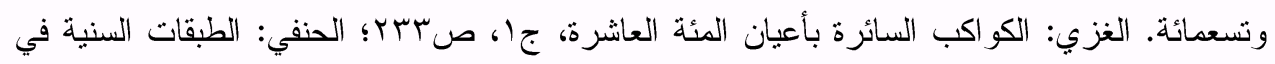

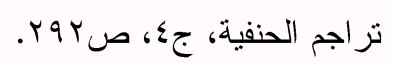

(T Y ( ) صيغة تأثيرة القاضي عبد الرحمن بن علي بن المؤيد علي يسار الصفحة. 
والإحتشام فيروز بك بن عبدالحي الوالي بلواء ولاية(rv) بوسنة(rr) أدام الله

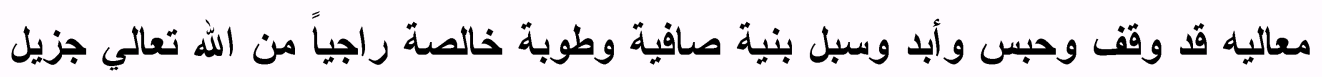

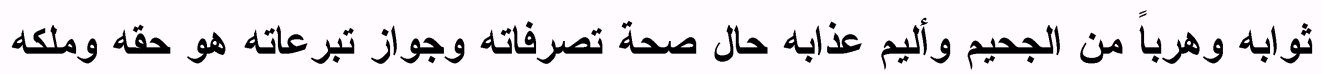
وفي يده وتحت تصرفه إلى أن صدر هذا الوقف منه وذلتك جميع الدار الحاوية علي بيوت متعددة علوية وسفلية (لوحة ه).

ظهر الورقة العشرين: وعلى صفف ومطبخ ومخبأ وحمام واصطبل وجنينة في

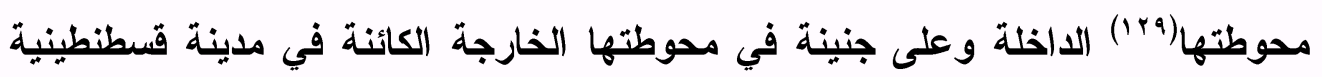

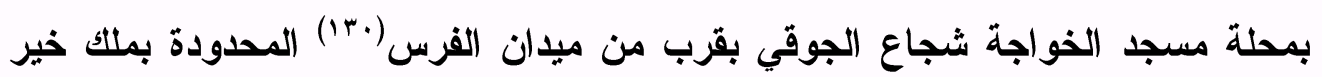

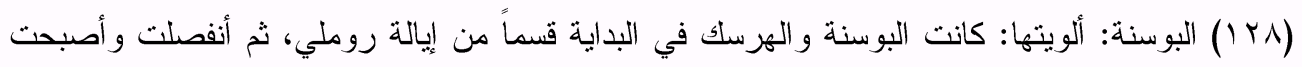

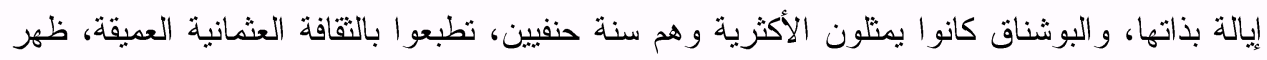

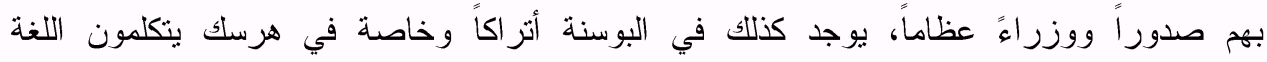

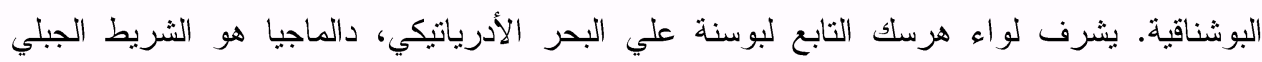

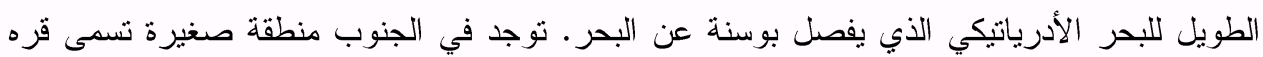

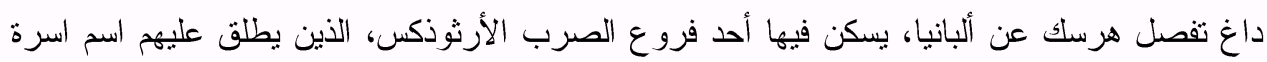

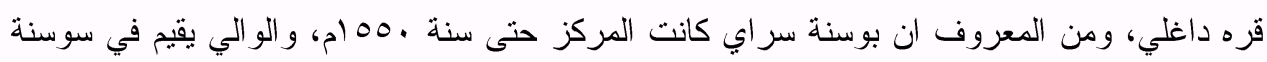

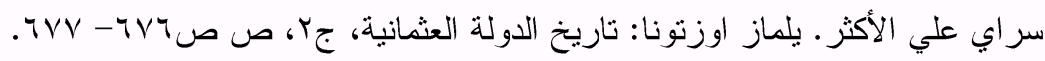

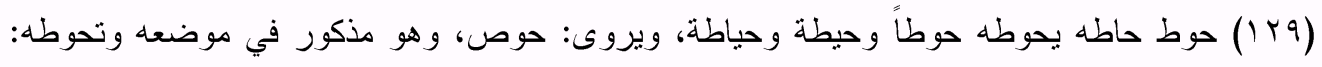

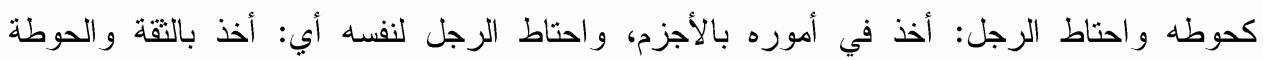

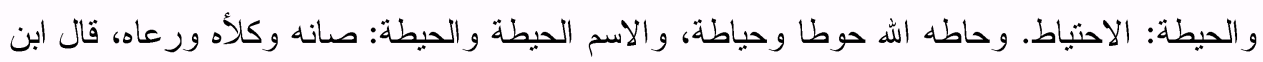

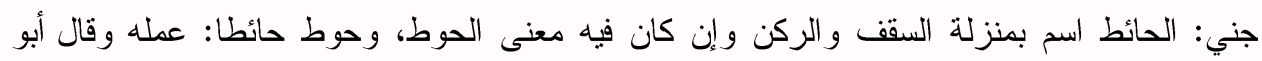

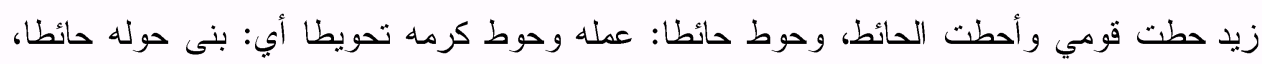

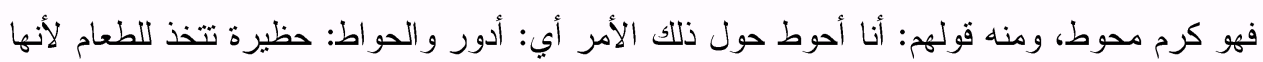

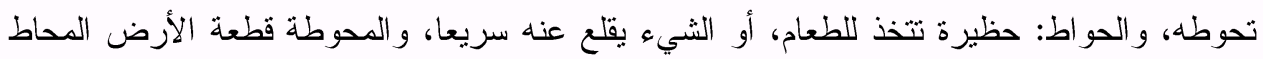

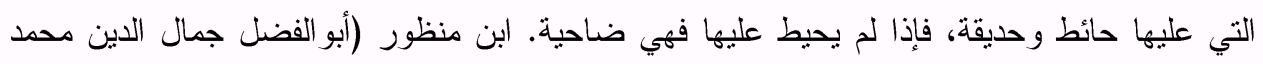

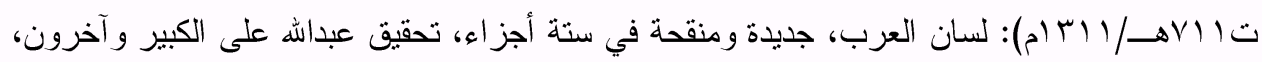

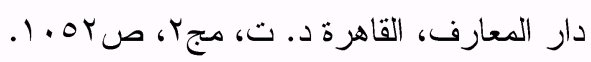

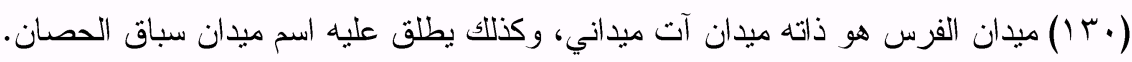


الاين بن عبدالله وبملك محمد جلبي الثهير بابن العجايب وبملك بيري جلبي (ابr) وبملك ورثة حاجي خوشقدم(rrr) وبالطريق العام في الطرفين مع السرداب الكبير الواقع تحت

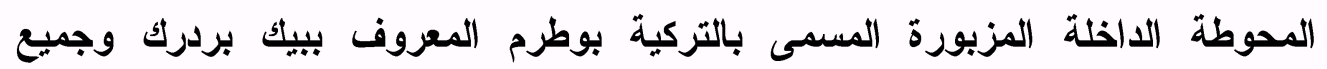

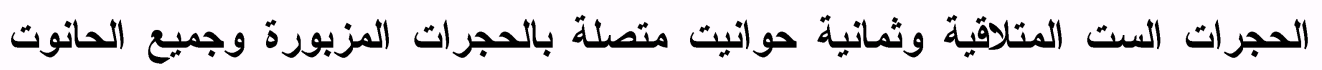
الرواسي المتصل بالحوانيت المزبورة الكائن كلها في المدينة المزبورة بمحلة مسجد باتبه الواقف المزبور المدود بوقف الواقف المذكور وبالطريق العام وجميع قطعة أرض خالية طولها سبعون.

وجه الورقة الواحدة والعشرين: ذراعاً وعرضها ثمانية عشر ذراعاً ونصف

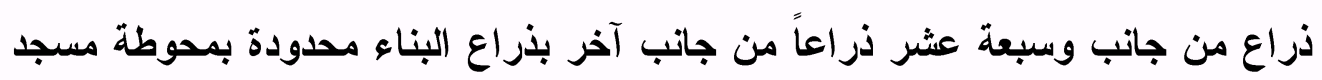

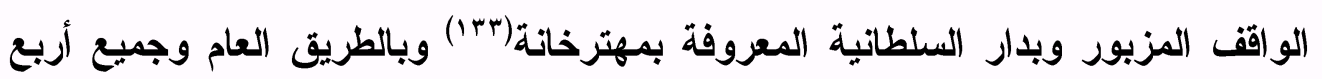

(1) (1) بيري محمد باثا: هو الصدر الأعظم العثاني الثهير، تلقي تعليمه علي يد عظماء علماء عصره،

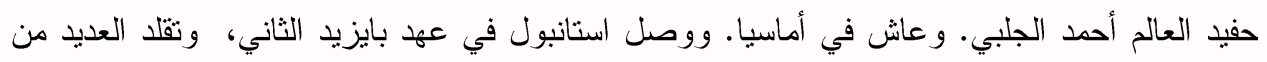

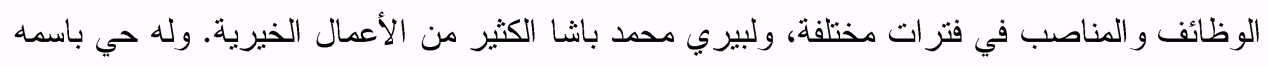

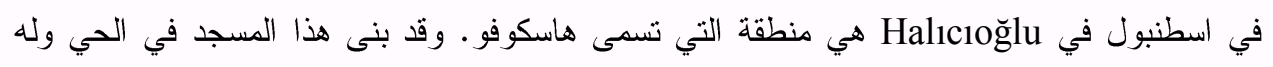

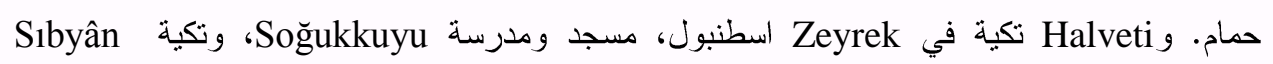
mektebi

YusuF KüçüKDAG: PIRi MEHMED PAŞA, Ramazanoğlu, islam ansiklopedisi, Ankara 2007, cilt. 34, s. 281.

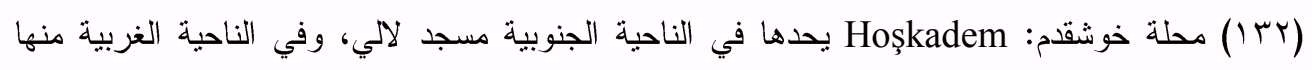

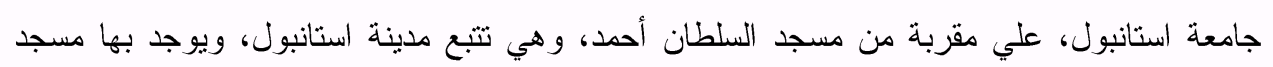
http://www.haritamap.com/mahalle/hoskadem مشهور يسمي مسجد خوشقدم، ومما يؤسف له أنه في حالة سيئة. Abdülkadir Özcan: HOŞKADEM, islam ansiklopedisi, Ankara 1998, cilt.18, s. 250.

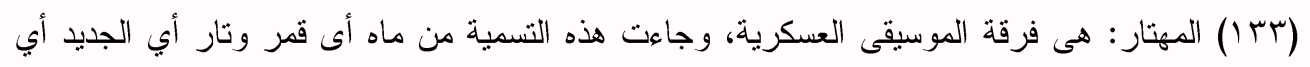

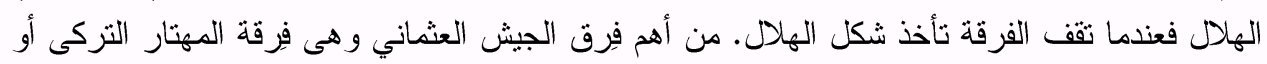

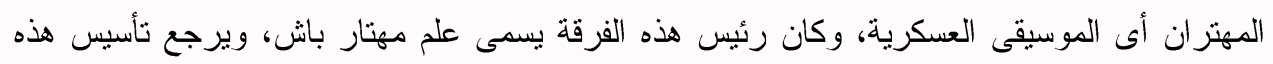

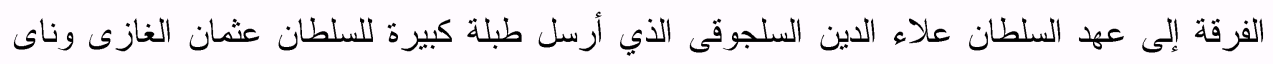

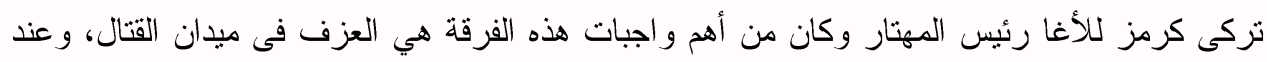

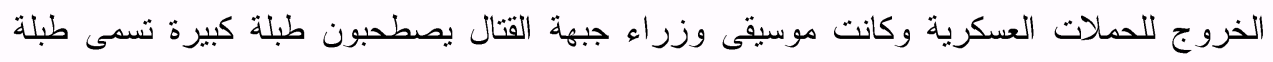

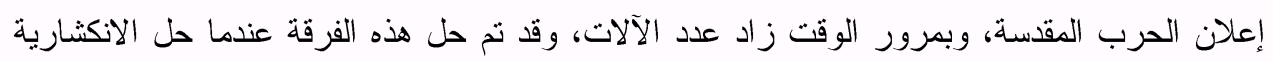


عشرة حجرة وثمانية حوانيت كائنة في مدينة قسطنطينية بالمحلة المعروفة بمحلة أمين

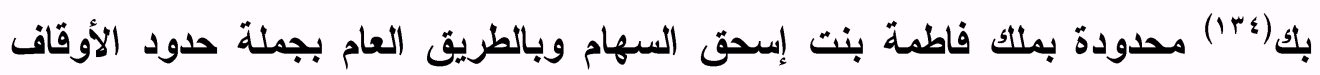

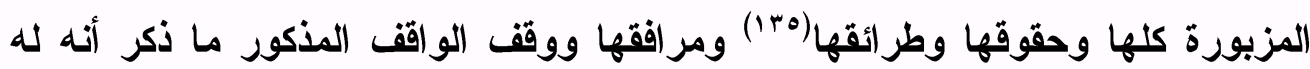

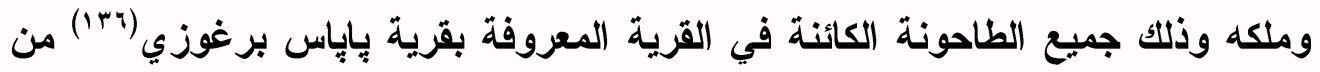

=فى سنة بr ام على بد السلطان محمود الثاني، وجاءت هذه التسمية من ماه أب قمر وتار أبي الجديد

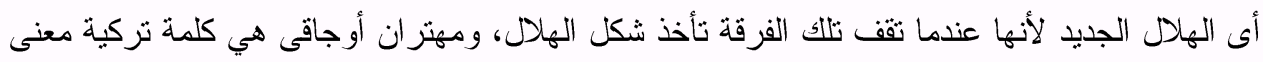

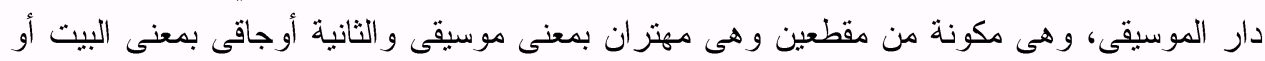

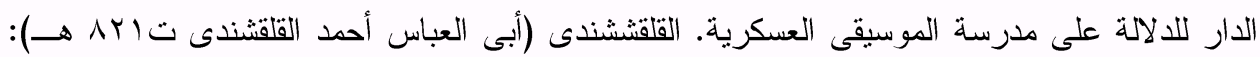

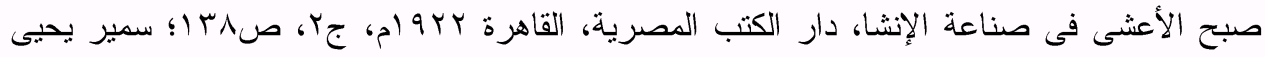

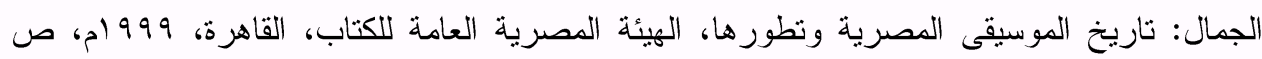
ص9-11؛ فيوتو : وصف مصر "الموسيقى و الغناء عند المصريين المحدثين، ترجمة زهير الثيايب،

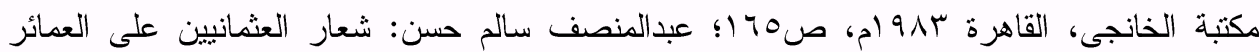
و الفنون في القرنين الثاني عشر والثالث عثر الهجريين وحتى إلغاء السلطنة العثمانية دراسة أثرية

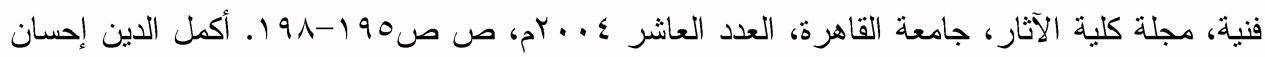

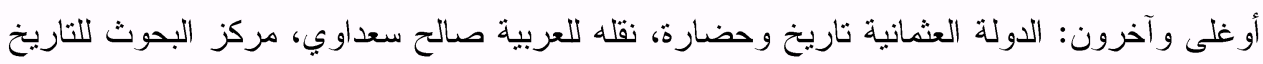

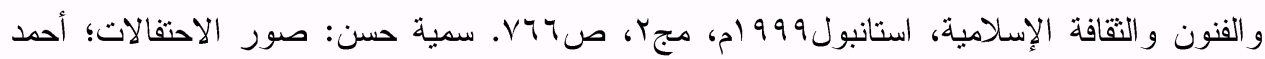

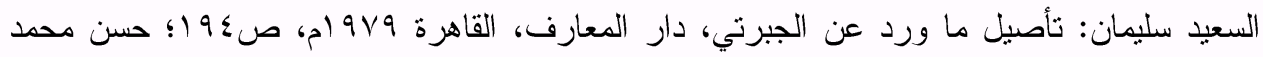
نور: صور المعارك الحربية في المخطوطات العثمانية، مخطوط رسالة ماجستير، كلبة الآثار جامعة دارئ

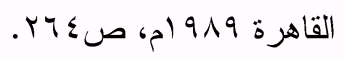

(؟r أمين بك: تقع محلة أمين بك سوكالك، بالقرب من قرية قاضي كوي، وقريب جداً من مسجد

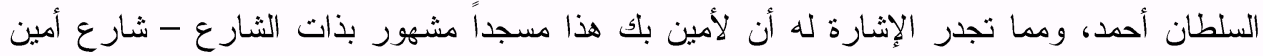

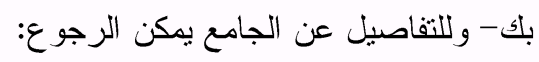

http://www.haritamap.com/yer/emin-bey-sokak-kadikoy,

Mehmet Canatar: 1009/1600 Tarihli istanbul Vakıflar1 Tahrir Defteri'ne Gore Nefs-i istanbul'da Bulunan Mahalleler ve Ozelliklerine Dair Gozlemler, s.299.

$$
\text { (1) (1) في الأصل كتبها بالثكل الإملائي وطر ايقها، وهذا يعد إبدالاً. }
$$

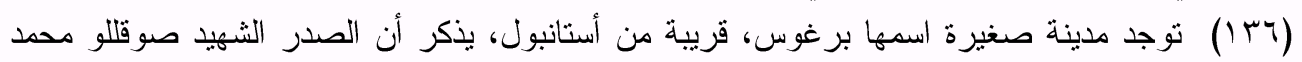

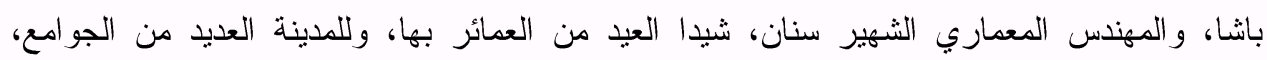

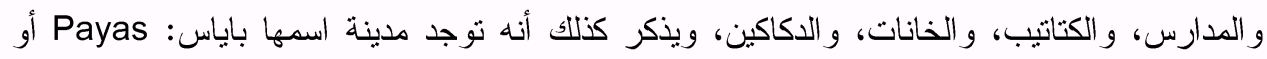
ياقاجك Yakacik مركز قضاء في لواء أدرنة المركزي، ميناء وقلعة، ويحنوي كلية صوقوللو

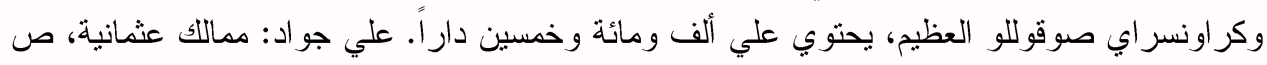

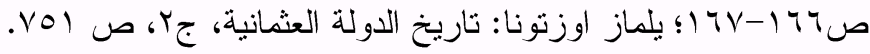


أعمال مدينة قسطنطينية الدائرة علي ماء النهر المعروف بقره صو (Irv) المستغنية عن التعبير والتعريف لكونها معلومة في محلها باسم واقفها بجملة أدواتها وأسبابها.

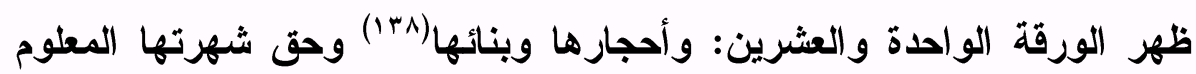

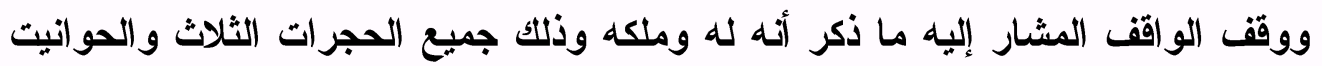

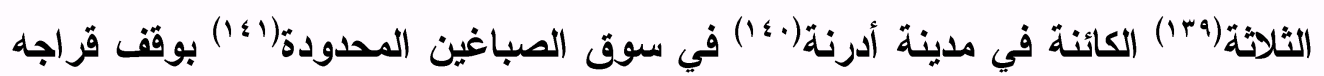

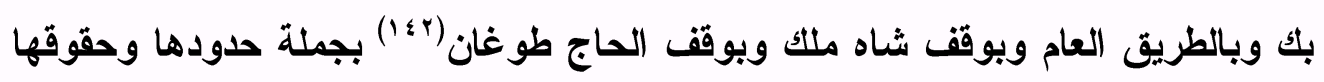

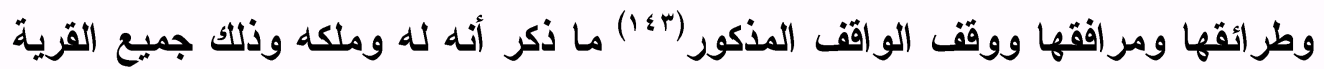

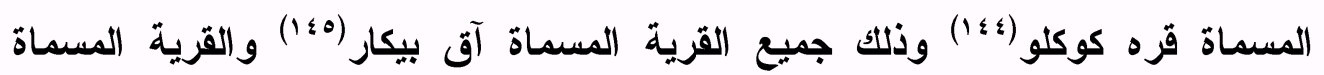

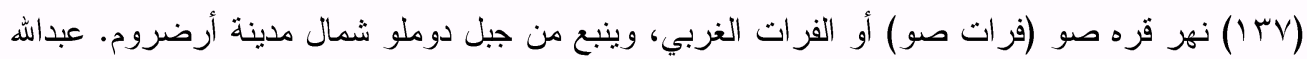

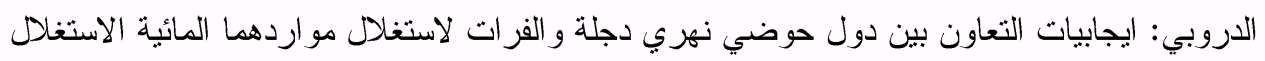

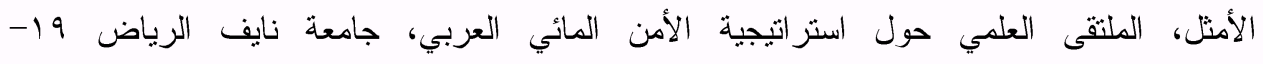

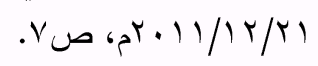

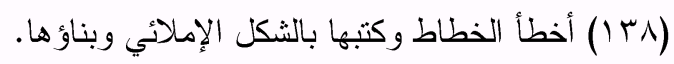

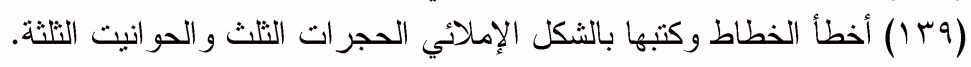

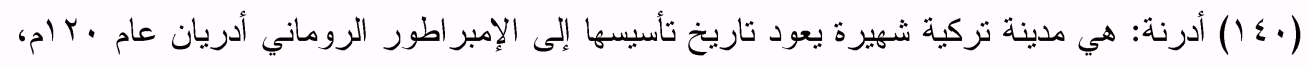

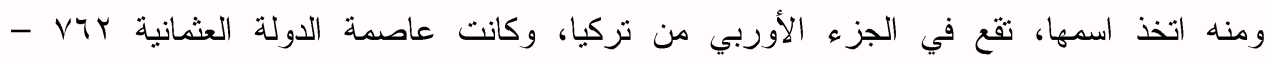

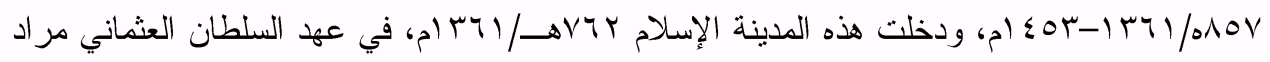

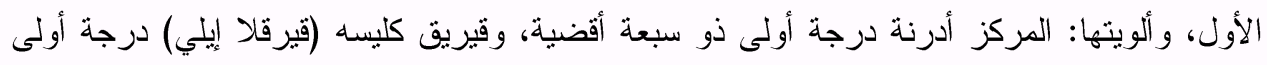

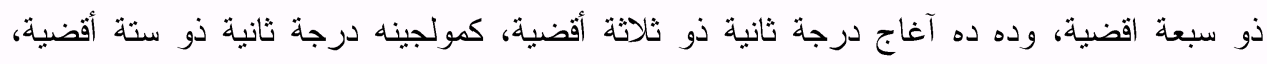

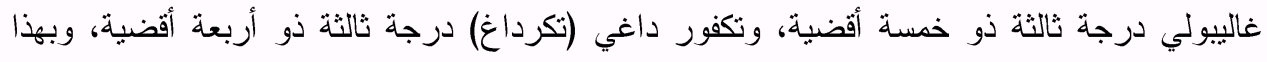

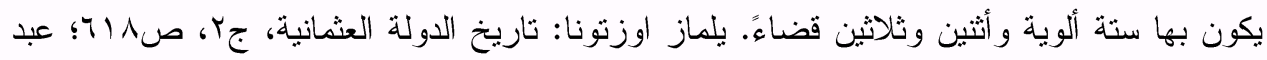

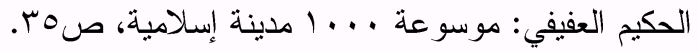

$$
\begin{aligned}
& \text { (1) (1) أخطأ الخطاط وكثبها بالثكل الإملائي المحدودها. }
\end{aligned}
$$

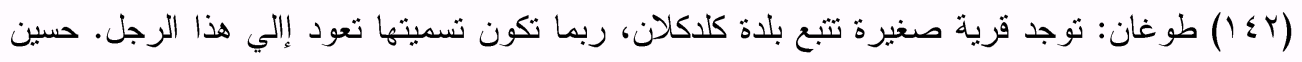

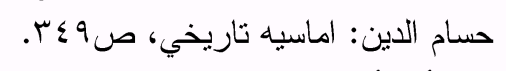

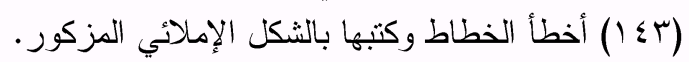

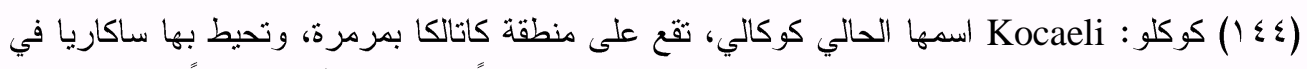

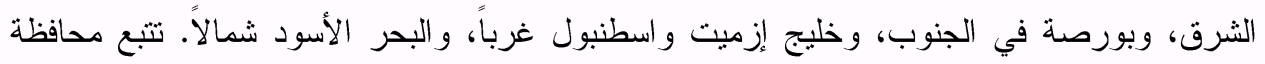

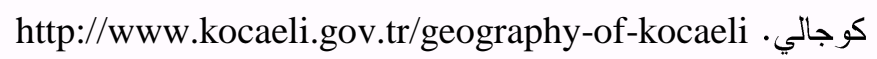

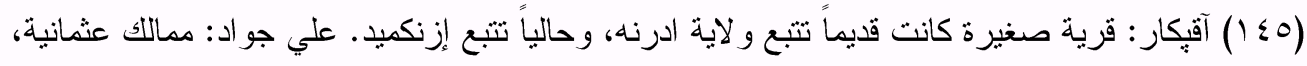




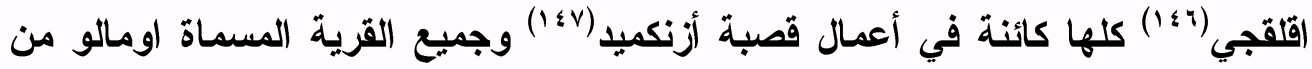
أعمال سنوسا(^ء1) وجميع القرية المسماة قِامل من أعمال محروسة اماسيه بجملة حدود القرى المذكورة(9؛1) وحقوقها وتوابعها ولواحقها جبالها وتلاهها عالها ومطمنيها أراحينها وكرومها آبارها وأنهارها مزارعها ومروجها ولكل حق هو لكل واحد منها أولى وهى واحد (لوحة آ).

وجه الورقة الثانية والعشرين: منها داخل فيها أو خارج عنها ذُكر أو لم يُّكر سُمي أو لم (10) يسم مستغنية عن التحديد والتعريف لعدم سمي كل واحدة منها في محلها ووقف الواقف المذكور جميع الحوانيت التي بناها في محروسة توقات وذلك عشرون حانوتاً وجميع حوانيته الكائنة في أطراف حمامه الكائنة في محروسة سيواس(101) مع لمع لئ

(7) (1) من المحتمل أنه يقصد آقجه قوجا - ولكن كتبها الخطاط كما وردت في المنن- وهو مركز قضاء

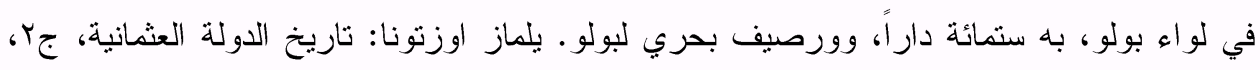
ص. ص. (iznikmid أو أزميت izmit ازنكميد، ميناء مرمرة، تقع في رأس الخليج المسمى بالاسم نفسه، مركز لو اء قوجه ايلي، ربطت بإلة البحر الأبيض (آقدنيز) عندما كانت لو اء في إيالة أناضولي، إذ أنها لو اء بحري وقاعدة بحرية، سميت المنطقة قوجا يالي نسبة إلي آقجا قوجا، أحد بكوات أمراء عثمان

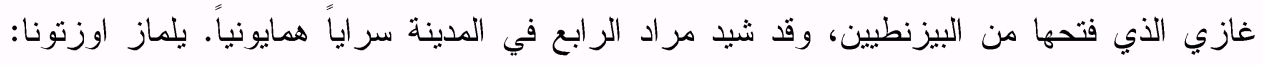

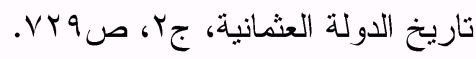

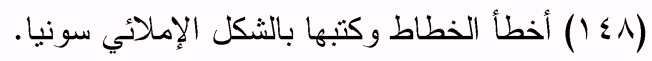

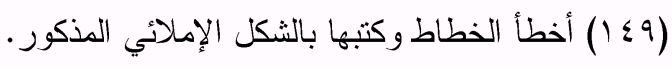

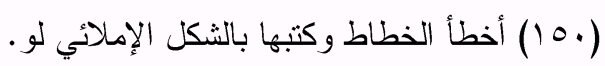
(101) سيو اس: مدينة في شمال وسط تركيا، غرب هضبة الأناضول، وتشغل جزءًا من فبادوفيا القديمة، و تحدها من الشمال و لايتا قسطمونى وطر ابزون، وشرقًا و لايتا أرضروم ومعمورة العزيز، وجنوبًا

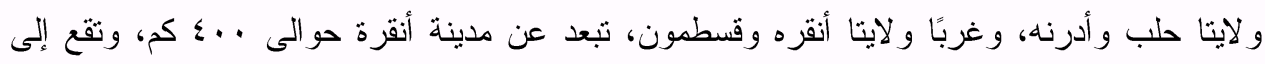

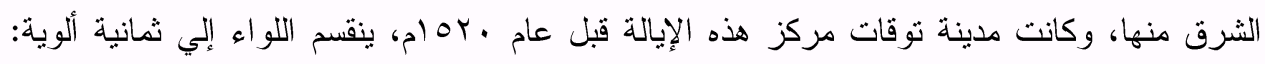

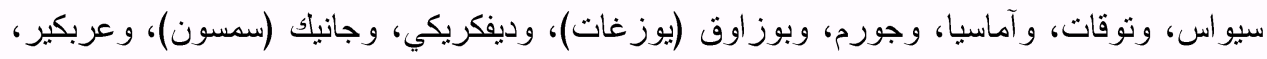

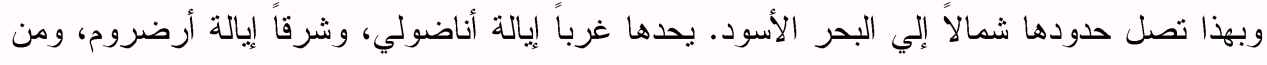

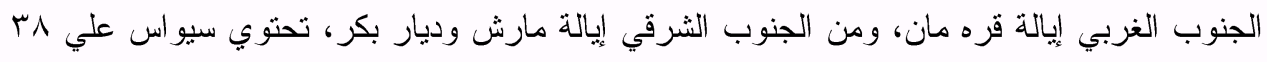

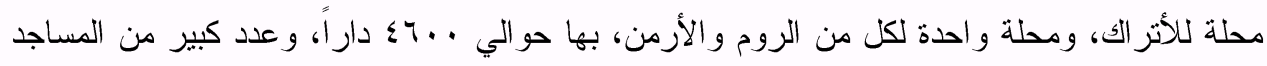

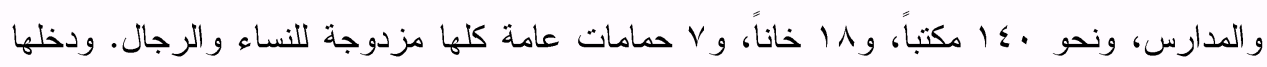


الأراضي الخالية الكائنة قرب الحوانيت المزبورة كل ذلك مستغني عن التحديد والتبيين

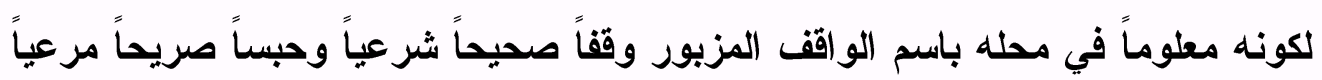

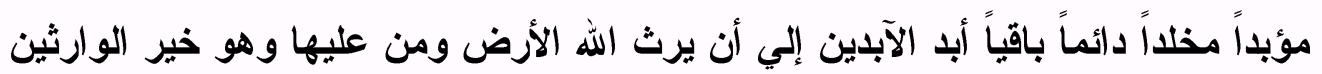
علي مصالح مسجده المذكور من مساجد مدينة قسطنطينية وعلي مصالح المكتب الكائن في محوطة المسجد المذكور وعلي مصالح المدرسة التي بناها الواقف المذكور.

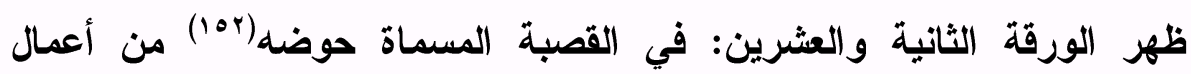
محروسة اماسيه ليصرف غلة الأوقاف المزبورة إلى مصارف المسجد والمكتب والمدرسة

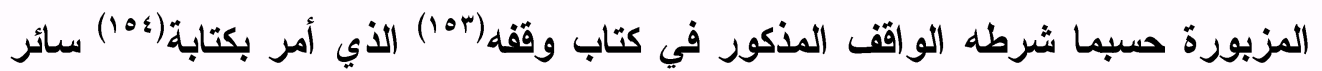
أوقافه ويصرف من غلة الأوقاف المذكورة أيضاً إلي ترميم مجاري الماء الذي ولئ أجراه الواقف المذكور (حسبة لله تعالي في قلعة سمندره وترميم مجاري الماء الذي أجري أجراه

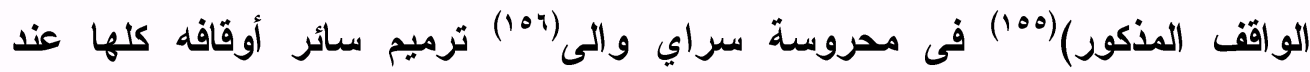
الإحتياج إليه وشرط الواقف المذكور أن يبني مما بقي عن المصارف المذكورة من غلة

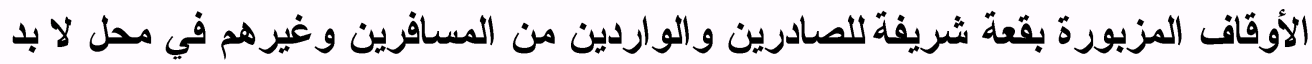
منها فيما ويصرف ذلك الباقي بعد تمام بناء البقعة المذكورة إلى الطعام للفقراء

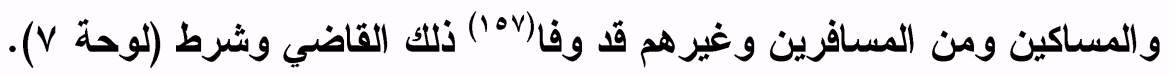

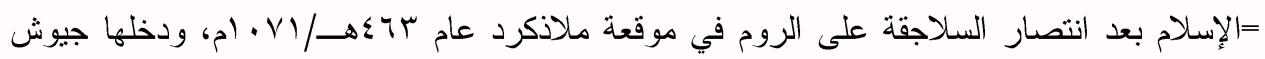
تيمورلنك التترى r.دهــ، وهزم جيش الأمير أرطغرل بن السلطان العثماني بايزيد. ابن دقماق صارم

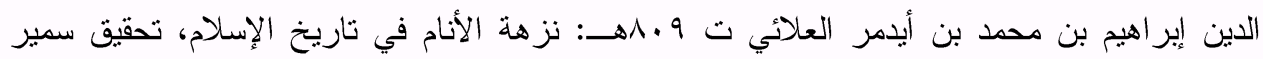

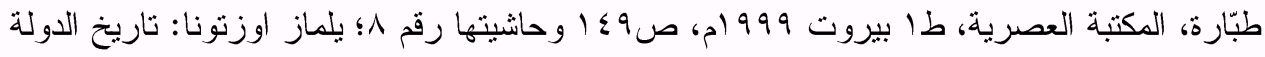
العثمانية، جr، ص ص صنr-vor.

ÜMER DEMiREL:SiVAS, islam ansiklopedisi, Ankara 2009, cilt.37, s. 278- 282.

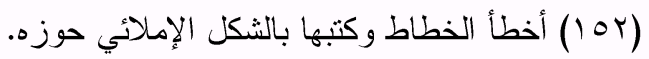
(10r) أخطأ الخطاط وكتبها بالشكل الإملائي وقف. (10 (10) أخطأ الخطاط وكتبها بالثكل الإملائي بكتبه. (100) هذا الجزء إستدر الك للخطاط وضعه على يمين الصفحة ناتج عن السهو .

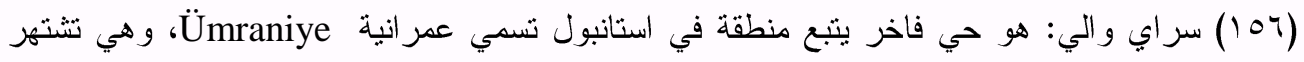
بوجود القصور الفخمة، علي مقربة من محلة أمين بك. http://www.haritamap.com/mahalle/saray-14918 (10V) ( أخطأ الخطاط وكتبها بالثكل الإملائي وفاء. 
وجه الورقة الثالثة والعشرين: أن يكون جباية أوقافه كلها للأصلح من عتقائه ثم للأصلح من أولاد عتقائه وأن يكون تلاوة الأجزاء المذكورة فى وقفيته السابقة لمن يقدر على تلاوة القرآن الكريم من أصلح عتقائه ثم للأصلح من أولاد عتقائه نسلة الألاً بعد نسل

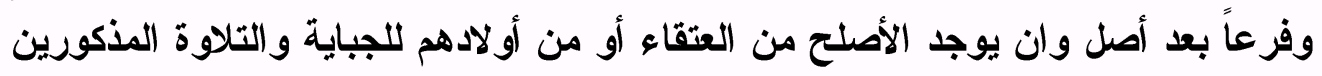

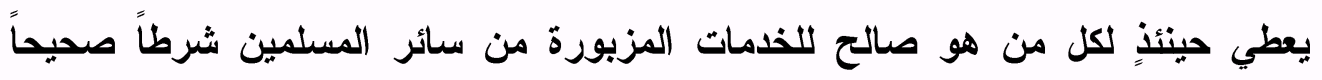

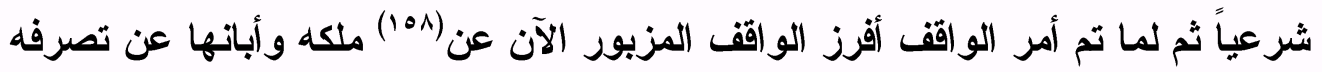
ونصب خير الدين حضر بن عبدالله الصوفي(109) من جملة خدام الواقف المزبور متولياً

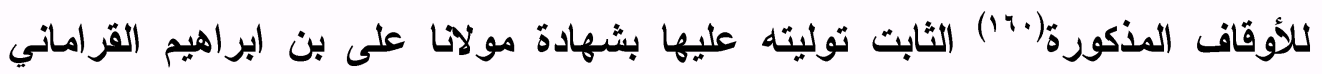
السندي مهري الخطيب سابقاً(17) في المسجد الجامع الكائن في محروسة.

(101) (101) أخطأ الخطاط وكتبها بالثكل الإملائي الآان. (09 109) المولى خير الدين حضر : كان رحمه الله تعالى اصله من بلدة مرزيفون وقرأ على على علماء عصره

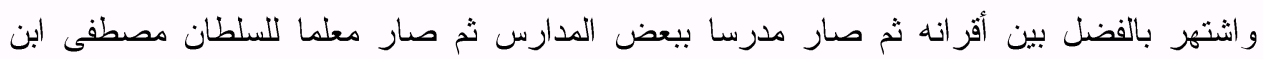

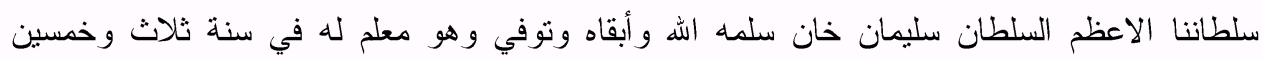

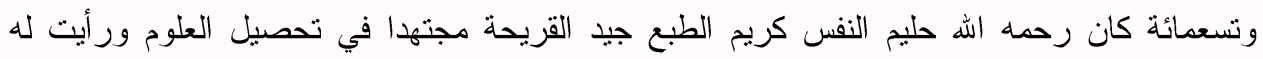

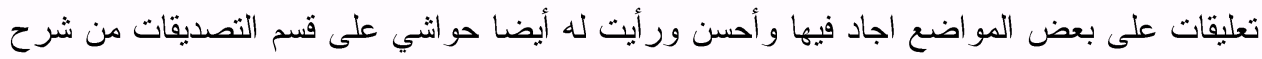

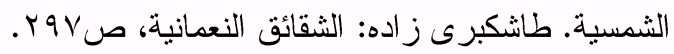
(17) (17) أخطأ الخطاط وكتبها بالثكل الإملائي المذكور .

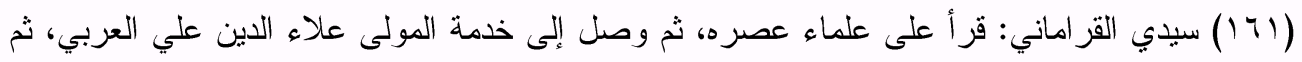

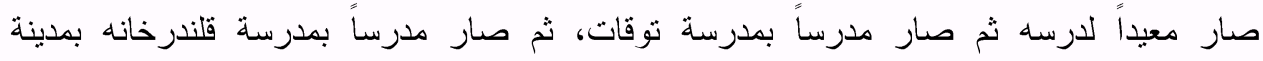

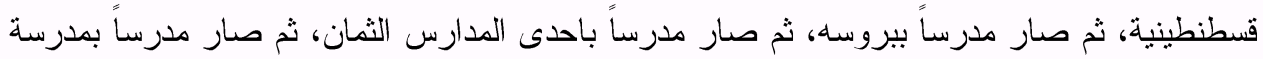

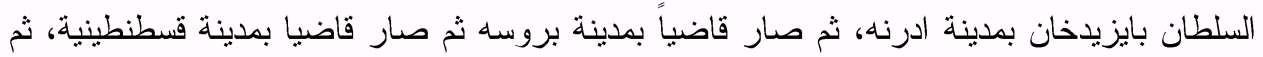

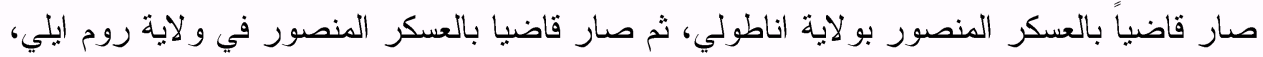

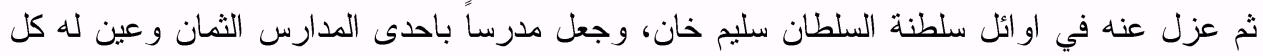

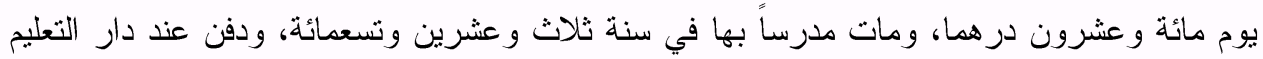

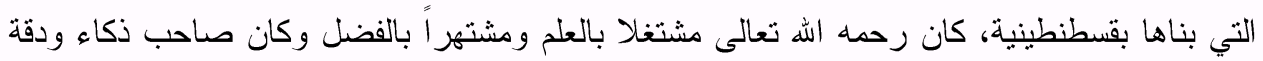

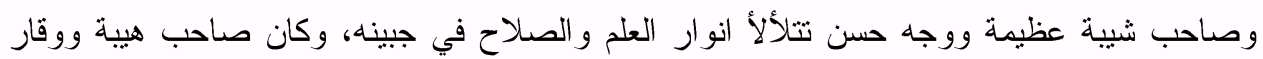

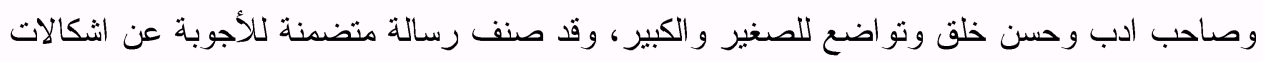

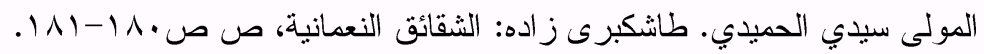


ظهر الورقة الثالثة والعثرين: سراي المزبورة وحسن بن عبدالله الحر من جلة خدام الواقف المزبور استعادها من المتولى المذكور قاسم بن عبدالله الزعيم من جملة الزئة خدام الواقف المذكور بوكالته بالرجوع عن وقفية الأوقاف المذكورة عن قبل الواقف

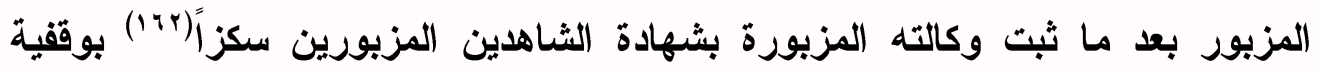
الأوقاف المذكورة ومدعياً عدم لزوم الوقف وصحة الرجوع عنه بـه بتقدير ثبوت وقفيتها

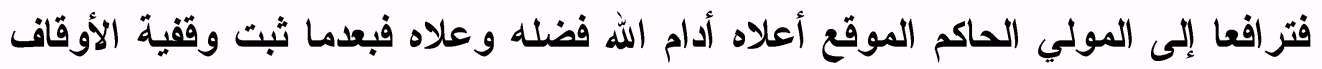

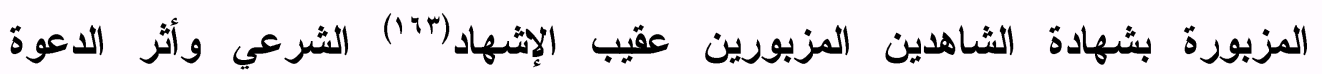

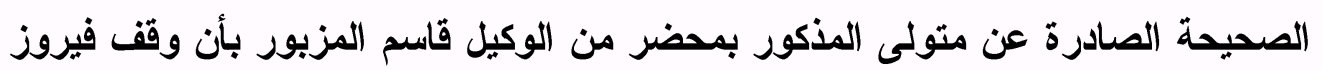
بك المذكور صاحب(ء11) الأوقاف المذكورة حكم المولى الحاكم المومي إليه لا زالت(170).

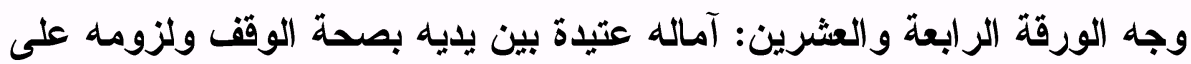

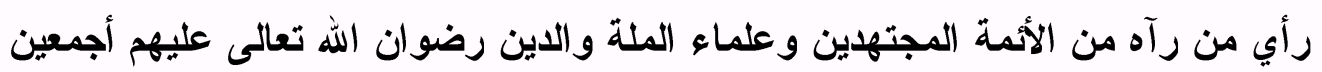

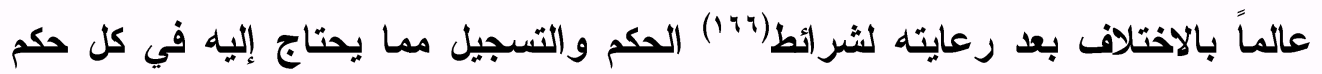

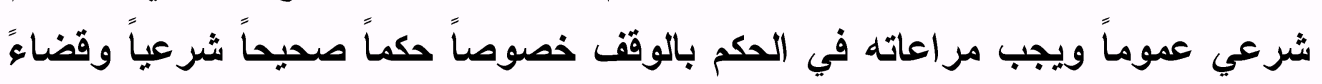

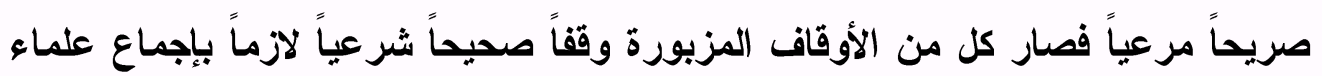

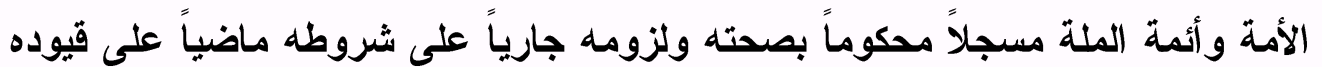

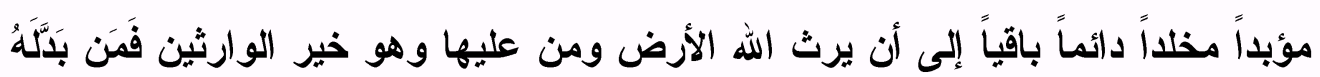

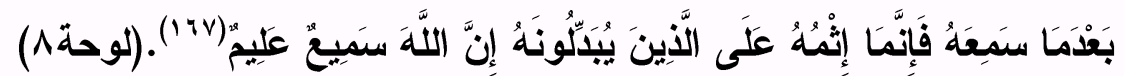
الار اسة التحليلية لشكل الوثيقة ومضمونها:

$$
\begin{aligned}
& \text { (YT (1) وردت هذه الكلمة كما هي بالنص. } \\
& \text { (T/7 (17) أخطأ الخطاط وكثبها بالثكل الإملائي الإنتنهاد. } \\
& \text { (ع 1 (1) سهّز الخطاط ولم يكتبها، و الكلمة إستكمال الباحث. } \\
& \text { (170) أخطأ الخطاط وكتبها بالثكل الإملائي لا زال. }
\end{aligned}
$$

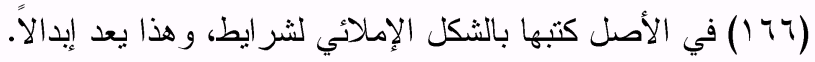

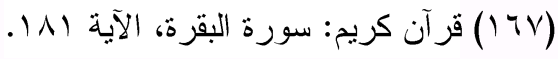


الوثيقة عبارة عن نسخة طبق الأصل من وثيقة وقف فيروز أغا، وموضوعها "الوقف" وأركان الوقف وهي: وقف، واقف، موقوف عليه وصيغه(14^)، وكل الأركان مذكورة في هذه الوثيقة، أي أن الوثيقة حوت أركان الوقف الأربعة. الوقف في اللغة الحبس والمنع، يقال وقَف يقِف وقفاً، ولا يأتي رباعيا "أوقف" إلا في لغة رديئة، ويُشتهر استعمال المصدر باسم المفعول، فيقال: هذه الادر وقف، أي موقوفة، ولهذا فإنه يثنى ويجمع عندئذ، فيقال: وقفان وأوقاف، ويأتي بمعنى السكون،

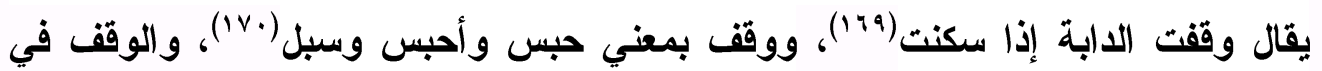
الاصطلاح عبارة عن تحبيس الأصل والتصدق بالمنفعة، علي جهة من جهات البر إبتداءً وانتهاءً)(1V1). ومن ألفاظ الوقف الصريحة - إضافة إلى لفظ وقف - حبس وسبل، منى تلفظ الواقف بها صار وقفا، لأن هذه الألفاظ ثبث لها عرف الاستعمال بين الناس، وأيد ذلتك الشرع بقول التبي صلى الله عليه و سلم لعمر: "إن شئت حبست أصلها وسبلت

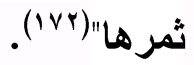

والوقف الخيري هو الأي يوقف في أول الأمر علي جهة بر خيرية، كالوقف علي المساجد، و الكتاتيب، والمستشفيات، والمدارس، ودور الرعاية، وغيرها من جهات البر

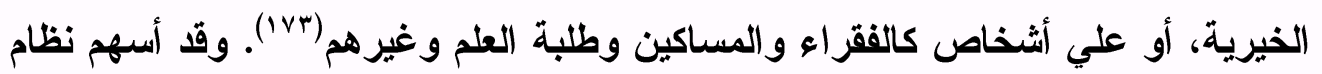

(1) (1) للتفاصيل عن الوقف وشروطه وصيغه و النية والعقد وغيرها يمكن الرجوع إلى: مصطفي أحمد

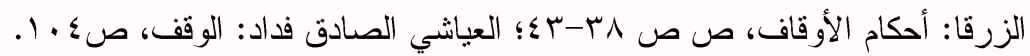

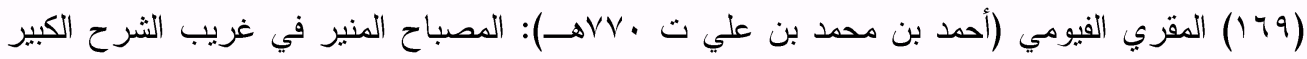

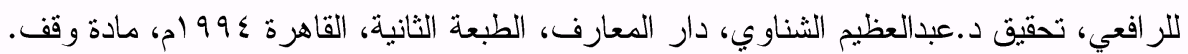

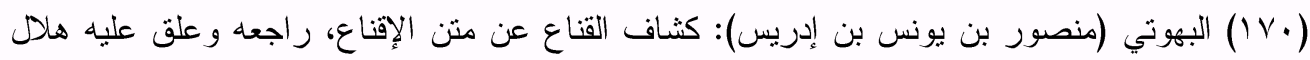

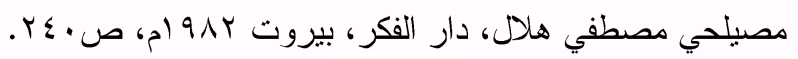
(IVI)

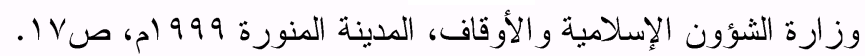

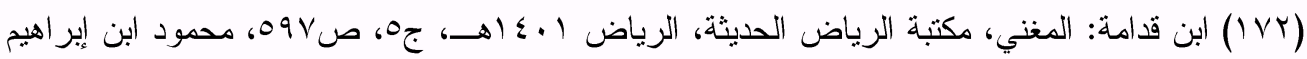

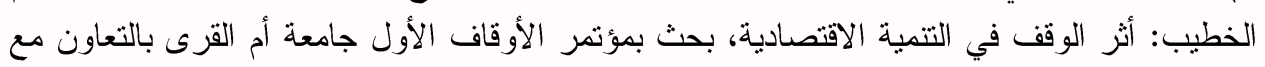

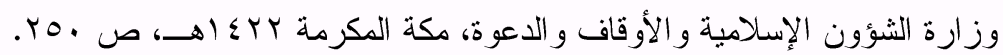

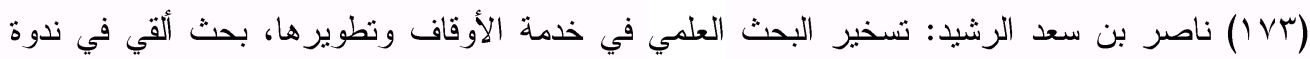

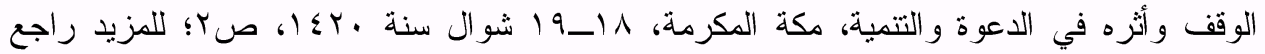

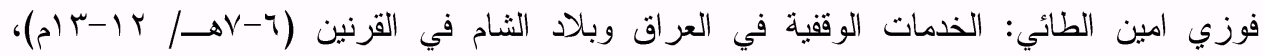

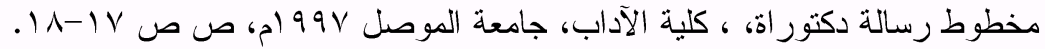


الوقف في العصر العثماني بدور كبير في حياة المسلمين، يتضح هذا من دراسة وثائق

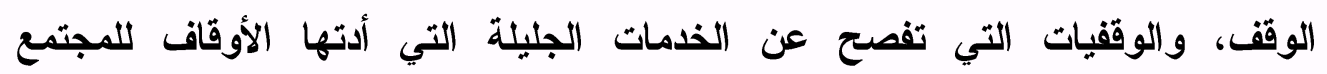

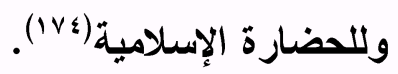

أهم أهداف الأوقاف في الإسلام بالتوصيف الاقيق، هو أن يكون ريعها صدقة

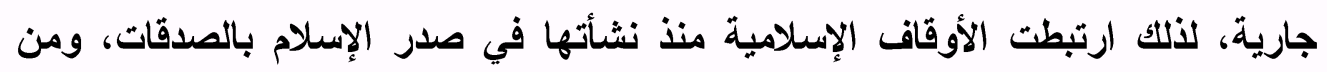

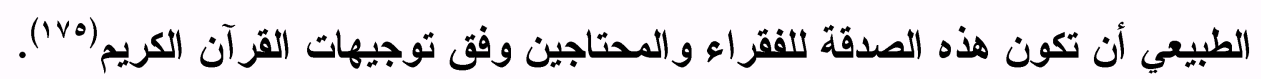

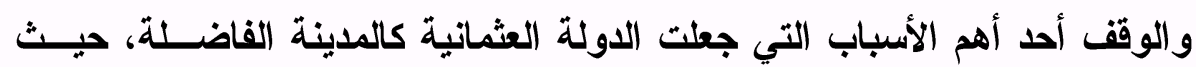

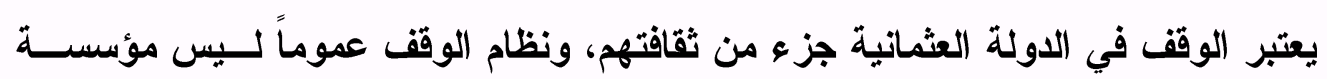

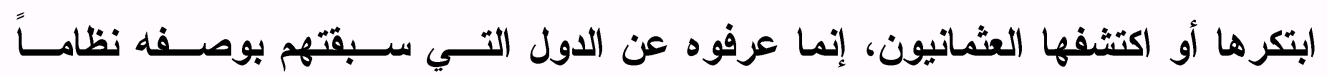

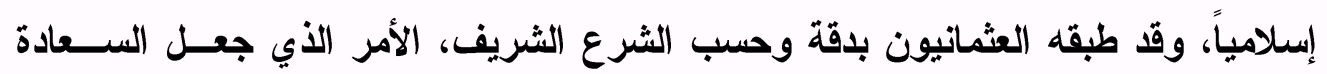

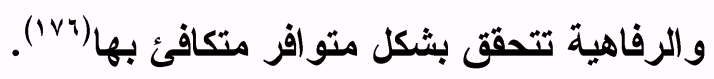

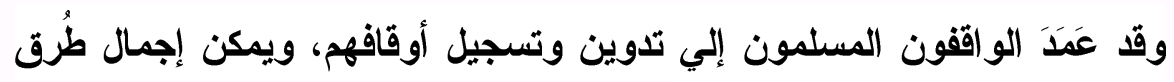

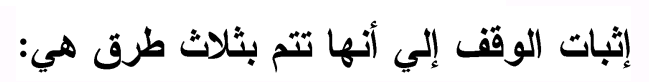
1- كتابة وثيقة وقف شاملة تبين الحدود والأهداف العامة وتسجل أمام القاضي. r - كتابة نص الوقفية علي الكتاب نفسه، وهو أكثر شيوعاً.

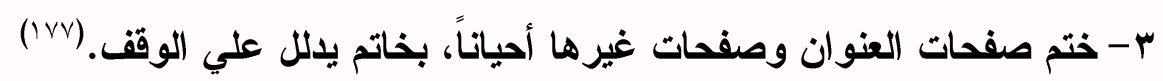

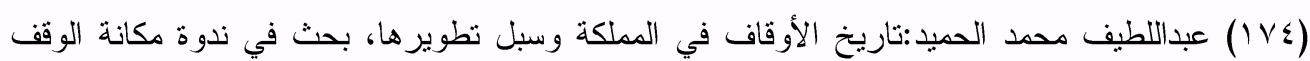

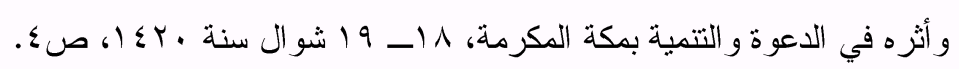

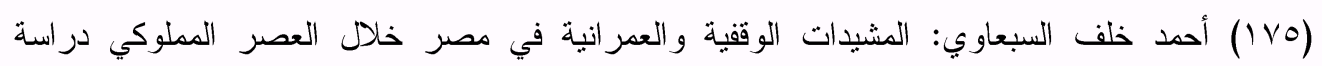

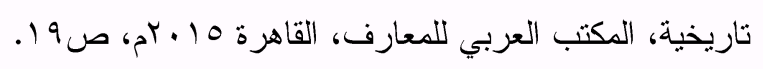

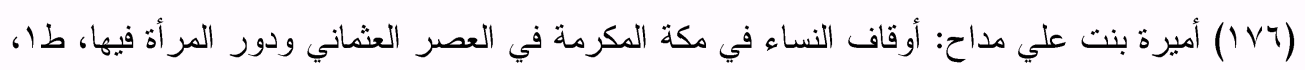

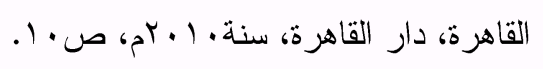

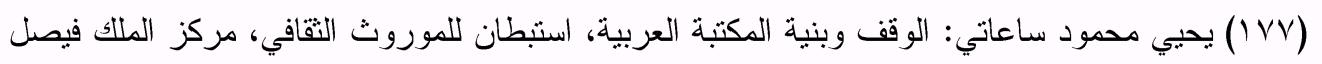

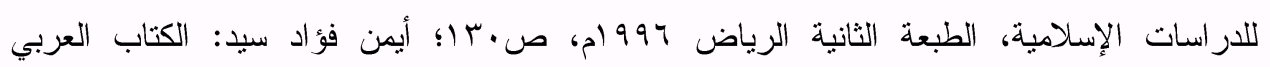

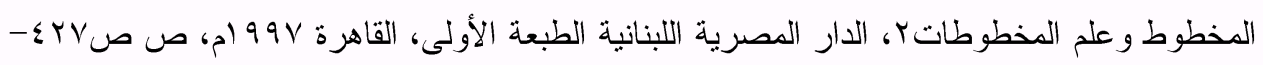

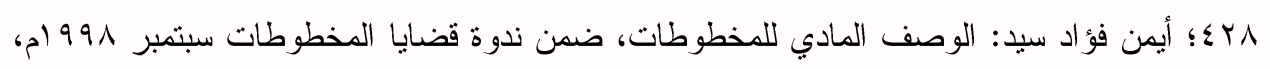

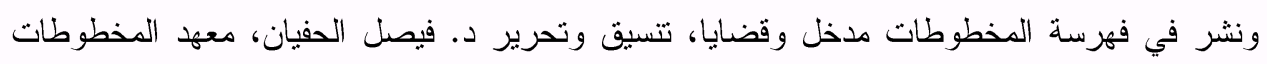


نفذت كتابات الوثيقة بالخط النستعليق، وأستخدم الخط الثلث في البسملة، منفذة جميعها الحبر الأسود علي أرضية خالية من الزخارف؛ كي لا تؤثر علي قراعة الكلمات، اللهم فيما عدا خطوط ونقاط تحديد من الحبر الأحمر بين السطور لتكون فاصلة، وتساعد

$$
\text { الخطاط كي لا بحيا عن سطوره. }
$$

اللغة المستخدمة في كتابة هذه النسخة طبق الأصل من الوثيقة هي اللغة العربية وليست التركية؛ وليس بغريب انتشار العربية(IV^) واستخدامها في المكاتبات الرسمية، لإضفاء صفة الشرعية عليها، وخاصة استخدام الآيات القرآية والأحاديث التبوية؛ ويرجع ذلك إلى عدة عوامل منها الإقبال على اعتناق الإسلام ودراسة قواعده مما أدى إلى ازدهار اللغة العربية وهجرتهم لغير العربية، ودرسوا علوم الدين وصنفوا مؤلفات في إلي

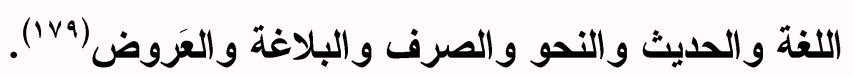

استخدم الكاتب اللغة العربية الصحيحة، في كثير من المواضع، مع ملاحظة استخدام اللهجة العامية وعدم الالتزام بقواعد النحو والإملاء مثثما وجدنا في العديد من من مئ من الكلمات، والتي صححتها الدراسة في مواضعها، وتجدر الإشارة إلي أن الكاتب يستشهر بالقز آن الكريم دون وضع علامات التنصيص. ولغة كاتب الوثقة بغض النظر عن الرسم الإملائي المعتاد في تلك العصور، لغة أدبية محكمة، تنوعت ما بين الجمل الطويلة والقصيرة، وما فيها من تراص وتوازٍ، ارتفع

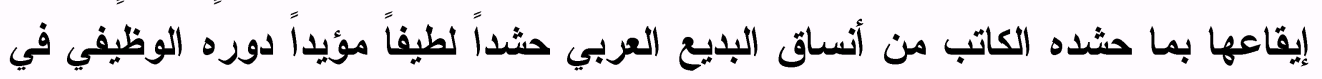
الادلالة و التبليغ. كتبت هذه الوثيقة بخط النستعليق المراعي إلي حد ما قواعده المعمول بها، وخط النستعليق هو خط متداخل الحروف وذو التواعات متعددة، تبدو فيه الحروف المنفصلة وكأنها متصلة، وتظهر الكثير من الكلمات التي تكتب به وكأنها متلاصقة لهذا فانه من الصعب تبديل حروف التعليق أو التغييز عليها، وربما كانت هذه الميزة هي التي دفعت

(IV^) Sheila S. Blair: Arabic inscriptions in Persia, Encyclopaedia Iranica; http://www.iranica.com/articles/epigraphy.

$$
\begin{aligned}
& \text { (IV9) عصام عبدالرؤوف: الدول المستقلة في المشرق الإسلامي منذ مستهل العصر العباسي حتى الغزو }
\end{aligned}
$$

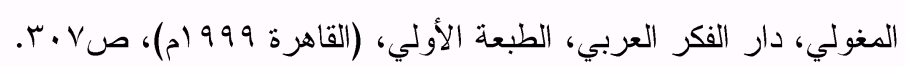

$$
\begin{aligned}
& - \text { rq }-
\end{aligned}
$$


إلى استعماله في المكاتبات الرسمية بشكل واسع، حتى سُمي بخط الترسل، وتكثر في خط التعليق المدات في كتابة بعض حروفه، ويغلب على حروفه وكلماته التفاوت في

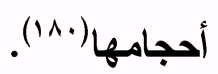

من الواضح أن الخطاط قبل أن يشرع فى كتابته، حدد لنفسه المساحات التي سيتم تنفيذ نصوص الوثيقة عليها، وكذا الخطوط الفاصلة بين الأسطر، لترتيب الكلمات

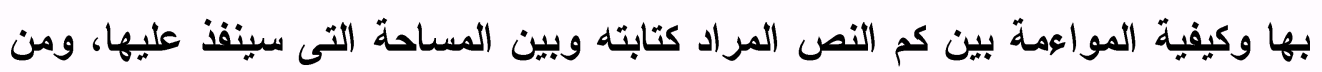
ثم تحديد الخط المستخدم وهو النستعليق، والأي يتفق وطبيعة مضمون النص، واختيار

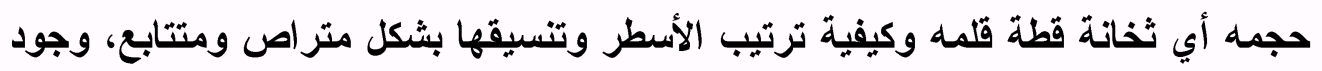

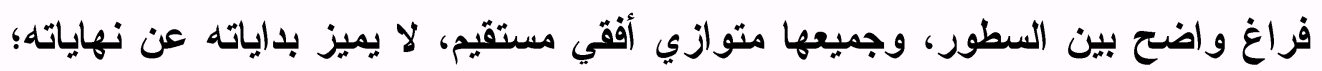
عكس ما هو متبع في الوثيقة ذات القطعة الواحدة، والتي تتميز بارتفاع نهايات أسطرها.

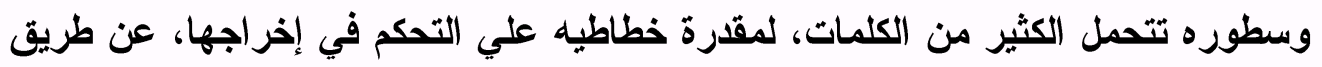

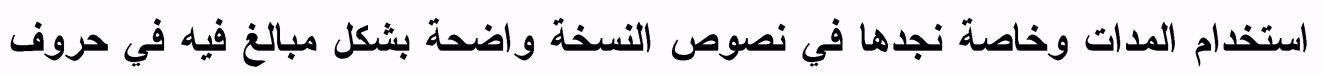
(السين والكاف و التاء (شكل ا ).

تميل حروف كلمات النسخة إلى اليمين من أعلى، وخاصة حروفها القائمة، مثلما

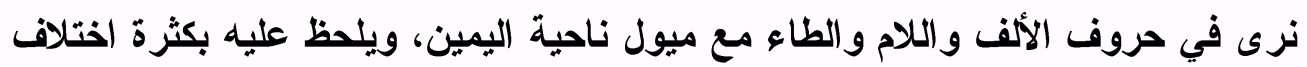
عرض حروفه من جزء لآخر في الحرف الواحد، ويرجع السبب في ذلك إلى استخدام

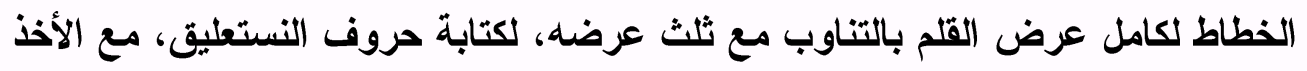
بعين الاعتبار أن تكون قطة قلم النستعليق أقرب إلى الاستقامة.

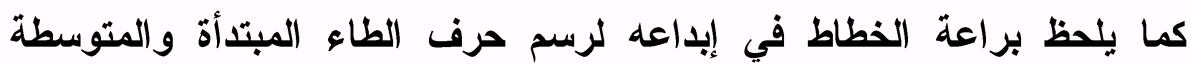
والمنتهية، وكذا التنوع المبدع في رسمه لحرف الهاء ذات الأشكال المتنوعة، كما أن

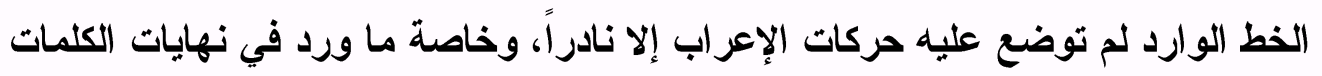
فقط، مما يجعله ملانماً للكتابة.

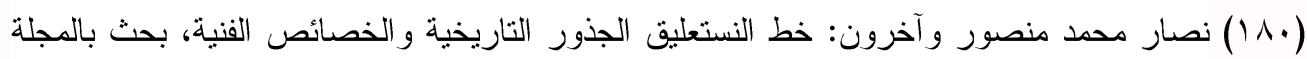

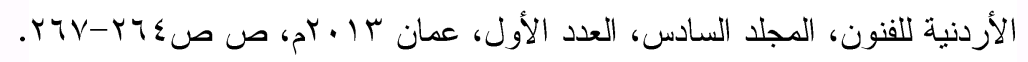


ويوجد بعض الملاحظات يمكن ان نلخصها فيما يلي:

ا - عدم وجود الهمزات علي الحروف: أعتاد الكاتب عموماً في مثل هذه الوثائق، عدم وضع الهمزات علي معظم الحروف، مثلما رأينا في كلمات الصفحة الأولى من نص الوثيقة- ظهر الورقة الأولى - أنشأ، وأبدع، والإنسان، والأركان، و الإلهية، والإيمان، وأعباء، وإستحقاق، وإقامة، والأموال، وأوقف، و إعراض، و إقبال، وإيثار، والمؤمنون، وأهل، والإيقان، والأحقاء، وإدرالك. كما تجدر الإثارة إلى ظاهرة قلب الهمزة ياءً، وهو ما رأيناه في كل كلمات الوثيقة، ومنها على سبيل المثال في الصفحة المشار إليها آنفاً كلمتا بسايط، وحقايق. ץ- كتابة كل الكلمات بخط متفق: لوحظ على الوثيقة، أن كل الكلمات فيها، كتبت بخط واحد، فلم يفرق الخطاط بين الكلمات والأفعال الدالة علي الوقف، أو أحد شخوصه الفاعلة أو المستفيدة منه أو القضاة أو الثهود، مثلما كان معروفاً ومتبعاً في الوثائق المفردة(11). اللهم فيما عدا اسم الواقف فيروز أغا، وجُّ عليه خطاً فاصلاً أحمراً أكبر من غيره، فربما يكون الخطاط عامداً لذلك للتمييز، وكذا وردت البسملة واسم السلطان بايزيد خان بخطٍ كبيز، أما فيما عدا ذلك فلم يميز الخطاط بين كلمات الوثيقة. r- عدم وضع التنقيط علي قليل من الكلمات: عدم وضع النقط علي قليل من الكلمات في نص الوثيقة، منها كلمة المصطفين في وجه الورقة الثانية، والأخلاق في ظهر الورقة الثانية، والفانية في وجه الورقة الثالثة، وكلمات المقربين، العلية، والسلطانية، والألسنية، والمرضية في ظهر الورقة الثالثة، وكذا معظم الكلمات الواردة في تواقيع وتأثبيرات القضاة في الجانب الأيمن من ظهر الورقة الثانية، والجانب الأيسر من وجه الورقة العشرين. ع - ظاهرة قلب الألف إلمى بائً مع إغفال حرف الألف أحباناً: عمد الخطاط في كتابته لتصوص وثيقته، إلى قلب الألف إلى ياءً مثلما رأينا في كلمات أحديها، 
وأحديها، وكذا رأينا إغفال وإهمال حرف الألف، في العديد من الكلمات منها ثلثة، وتثلثين.

ه - الخطأ في كتابة الآبات القر آنبة والأحاديث النبوية الواردة بالوثيقة: مما يؤسف له أن الخطاط قد وقع في أخطاء جسيمة، ومنها الخطأ في كتابة الآيات القر آنية

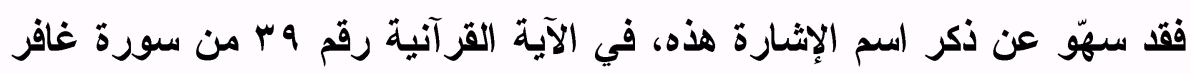

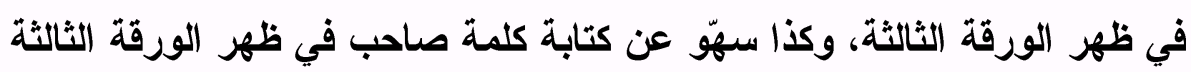
والعشرين، وأخطأ في كتابة اسم الإشارة ذا وكتبه ذي، في الآية القرآنية رقم

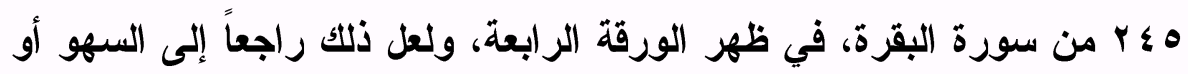
سرعة الكتابة.

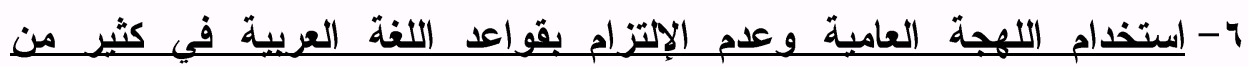
الأحايين: حاول الكاتب إلتزام قواعد اللغة العربية الصحيحة؛ ورغم ذلك إعتراه الضعف والركاكة في أسلوبه، فظلبت اللهجة العامية على كثير من جمله

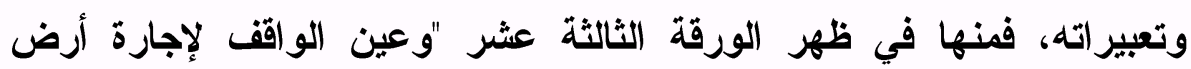

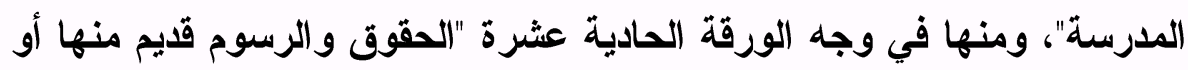

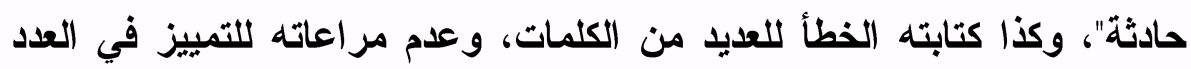
و المعدود، ومنها الدكاكين الخمس، وعشرة رجل، إضافة إلى الأخطاء الكثيرة والتي أُثْير لها في مواضعها وتم تصحيها في الهوامش، وكذا كتابته للتاء المربوطة تاءً مفتوحة مثل جمعيت خانه، ولعنت الله، وولايت. والغريب في الأمر

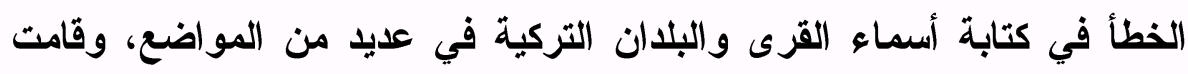
الار اسة بتصحيحها من المراجع والمصادر التركية الأصيلة. ثانياً المميزات الداخلية للوثيق: غلب على هذه الوثيقة الإلتزام بالمحنات البديعية ومنها السجع، والجناس

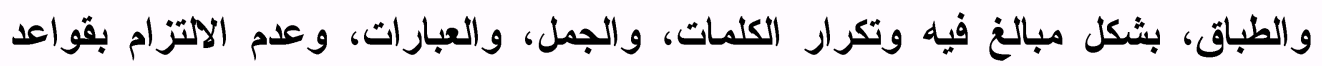

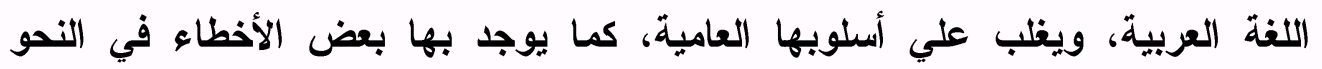

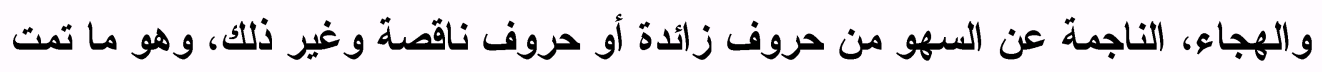
الإشارة إليه في مواضعه. بصفة عامة إلي قسمين: 
يختلف البروتوكول بإختلاف المحاكم أو الدواوين أو الأفراد، فقد يتفق البروتوكول في عدة وثائق ذات موضوعات مختلفة من بيع وإيجار وإسقاط،

بينما يختلف النص وينقسم البروتوكول إلي قسمين:

$$
\text { أ- البروتوكول الإفتتاحي: }
$$

ويشمل الجهة الصادر منها نسخة الوثيقة أي محكمة القسطنطينية، واسم

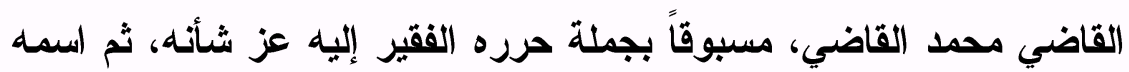
ووظيفته، ثم الدعاء له بعفى عنه. وهي بذلك تختلف عن الوثائق الأصلية،

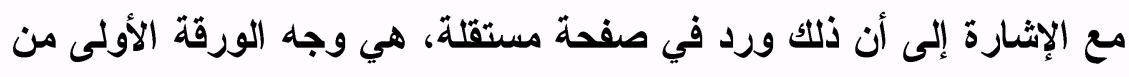

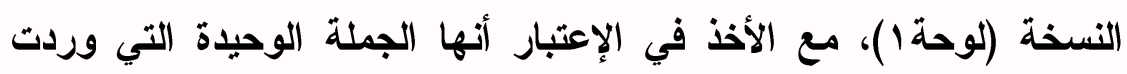
كاملة باللغة التركية. ثانياً - النص: بدأت النسخة هنا بالبسملة في سطر منفرد مستقل، تعظيماً لله سبحانه وتعالى، ثم

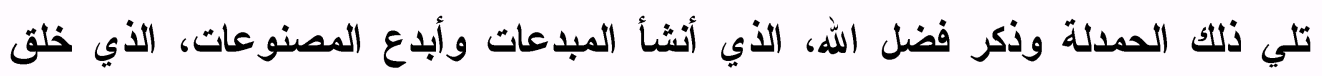

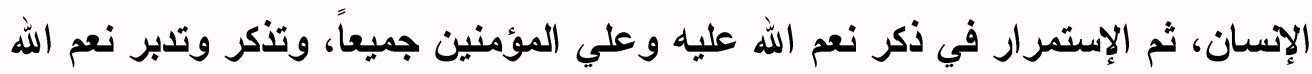
وكيفية الوصول لها والحفاظ عليها، والأمنيات الطيبة، ثم الصلاة والتسليم على النبي الني صلي الله عليه وسلم، ثم الإثارة طغراء السلطان بايزيد خان بن سلطان محمد خان.

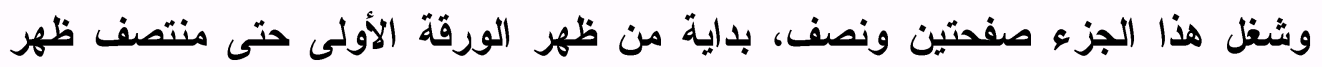

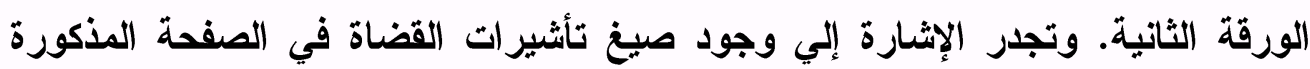

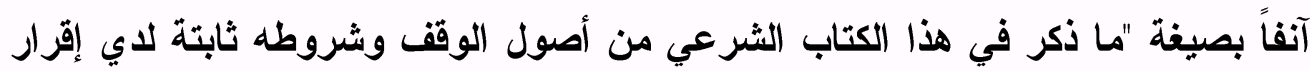
الواقف مولانا الفقير علي بن إبراهيم القاضي بالعسكر المنصور. وكذا "المحرر فيه مقرر عندي ومقبول بإقرار الواقف لاي وأنا أفقر الورى محمد بن مصطفى بن إنبا الحاج حسن القاضي بالعسكر المنصور في ولاية أناطولي.

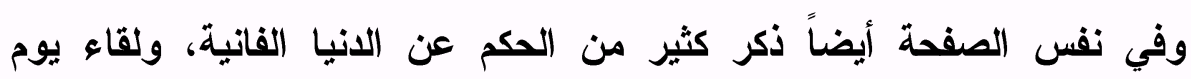

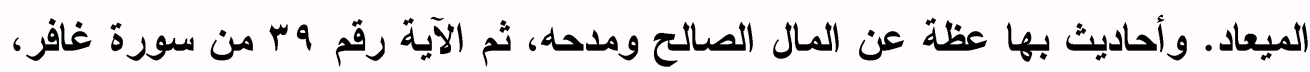

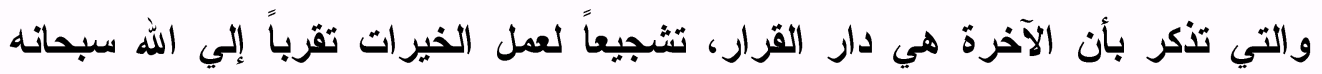


وتعالي طلباً لمرضاته، وانتهى ذلك في منتصف ظهر الورقة الثالثة، والتي بدأ من بعدها

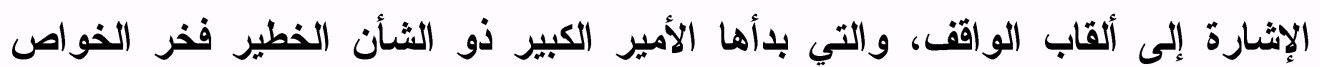

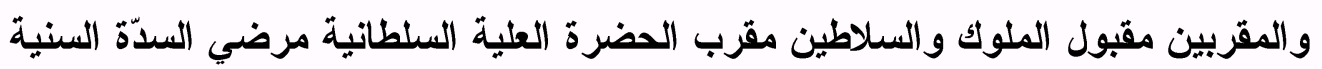
الخاقانية صاحب النفس القدسية والكمالات الألسنية والملكات الملكية والخصالات المرضية محرز قصبات السبق في مضمار الخيرات والحسنات فارس ميدان العطايا

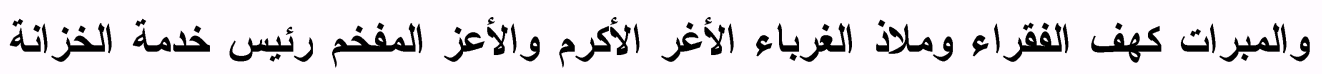

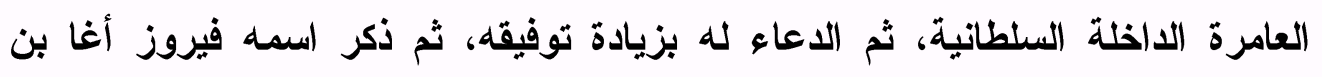
عبدالله ثم الدعاء له بتقبل حسناته وحسن الجزاء عن مبراته، ثم الاعاء للسلطان الأعظم والخاقان الأكرم بايزيد خان.

ثم يلي ذلك مدخلاً وتنويهاً عما سيرد بمضمون الوثيقة، بالإشارة إلي الأسباب

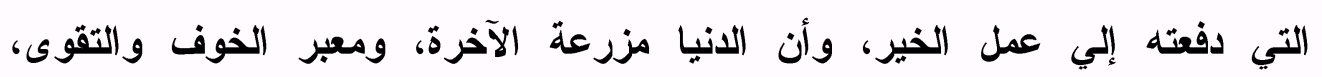

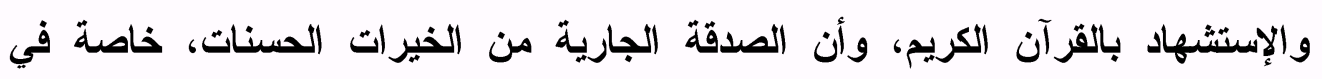

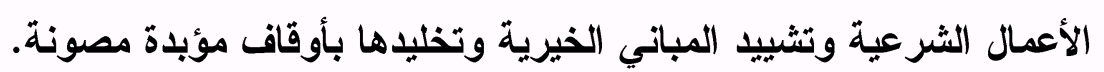
وتلى ذلك بيان الموقوفات وهي مدرسة رفيعة البنيان بليعة الأركان كأنها جنة

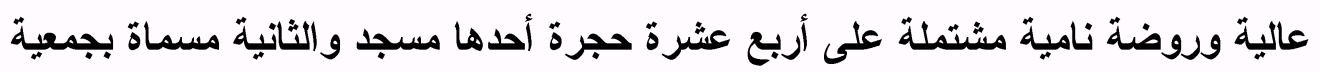

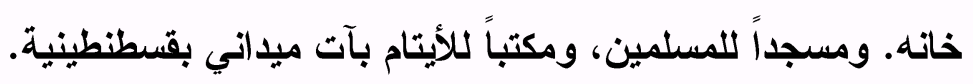

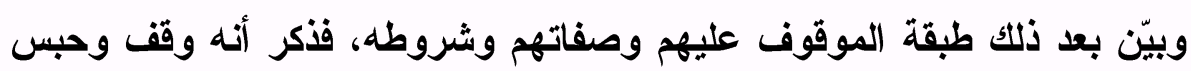

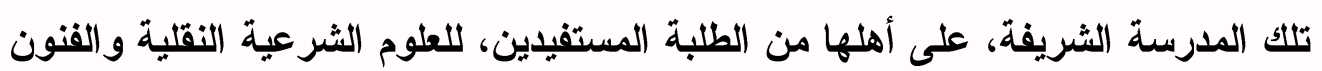

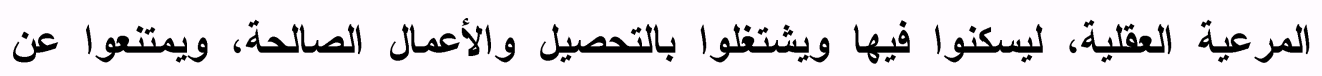
التعطيل والأفعال الطالحة، وكذا للمدرسين العالمين بالمعارف العقلية والنقلية العاملين بالآداب الدينية المعقولة المنقولة، ووقف المسجد علي المسلمين المصلين المقيمين الصلاة من الفرائض الفواضل والتطوعات والنوافل، ووقف المكتب الثريف على من الثن

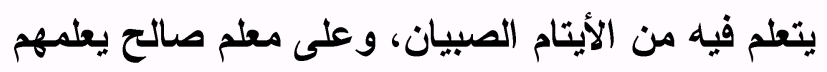

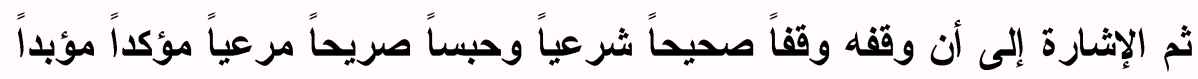

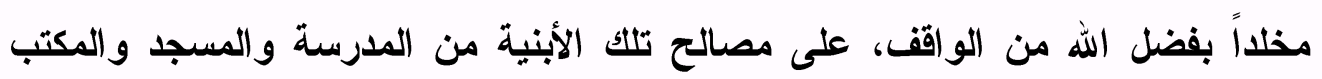


جميع ما يذكر في هذه الحجة الثرعية والوثيقة المرعية من القرى والضياعات وحصص مص ماتصات

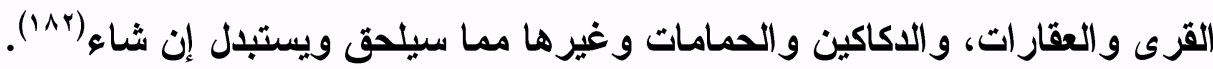

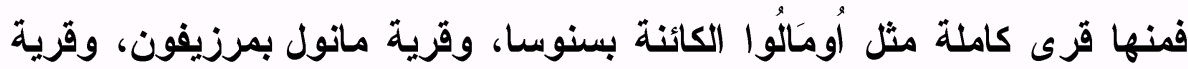
طثلو (يوك في ناحية كده غره، وجيع الثلث الثائع من القريتين اغجه قايه، وقره

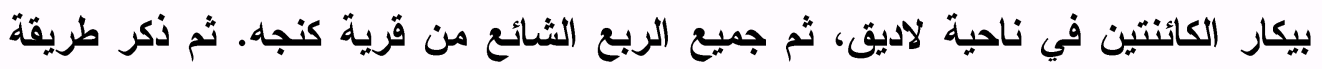

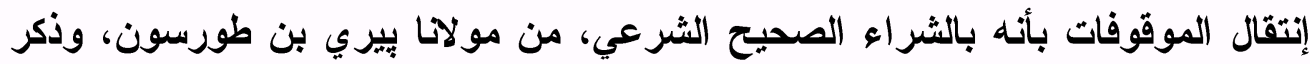

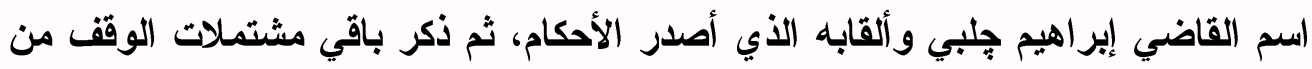
القري مع الحصص من القري والضياعات وغيرها والدكاكين والحمامات بجملة ما لها من الحدود والحقوق والمرافق، والتوابع واللواحق والمضافات والمنسوبات والثعاب والتلال والأودية والجبال والمساكن والأماكن و المزارع والمراتع و والكروم والأشجار

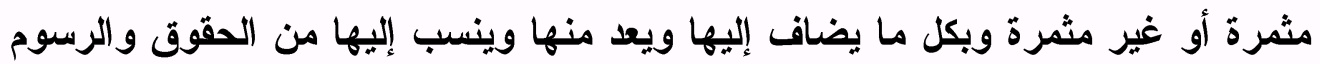
قديمة كاتت أو حليثة. ثم التأكيا على أن الوقف وقفاً صحيحاً شرعياً وحبساً صريحاً مرعياً جازماً لازماً

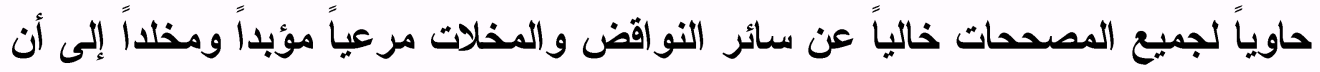
يرث الله الأرض ومن عليها وهو خير الوارثين لا يباع ولا يوهب ولا يرهن ولا يتلف. ولا تبديله و الوعيد و اللعنه لمن يخالف ذلتك. ثم شرط الواقف التولية والنظر والتصرف في أمور جميع الأوقاف بأسرها لنفسه

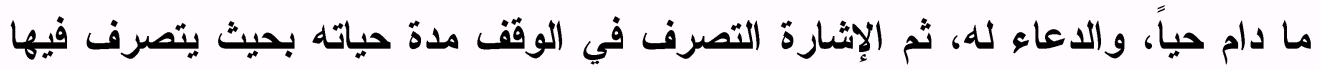

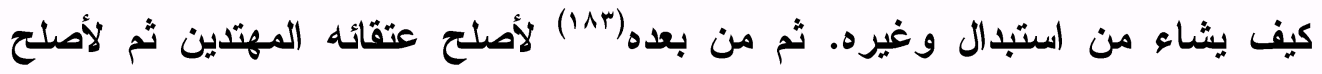

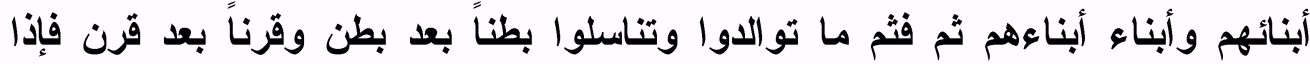
انقرضوا ولم يبق منهم أحد والباقي هو الله الأحد يكون أمر التولية والنظارة على ما يراه الثرع القويم. ثم حد مقتضيات وشروط من يتولى أمر هذا الوقف.

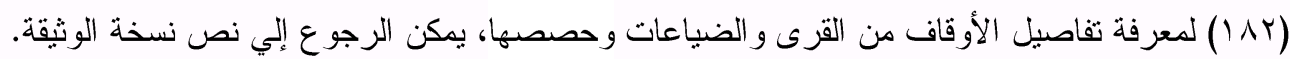

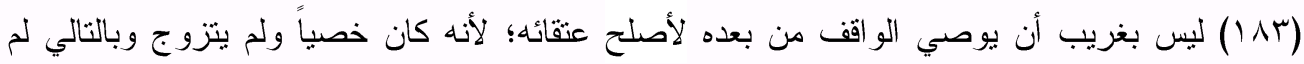

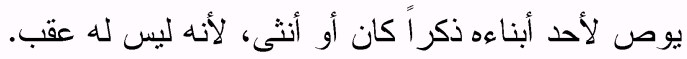


ثم تطرق للحديث عن المصروفات، بأن يصرف المتولي عُشر محصولات

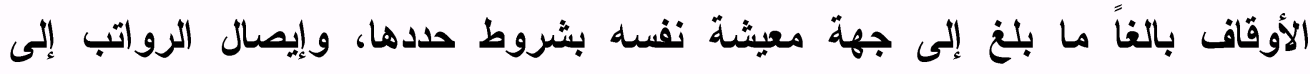

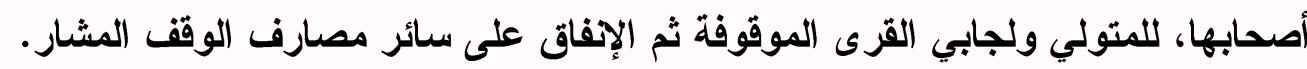

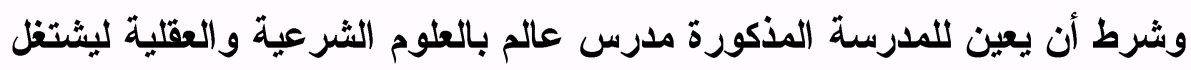

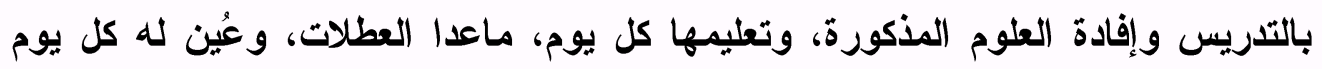

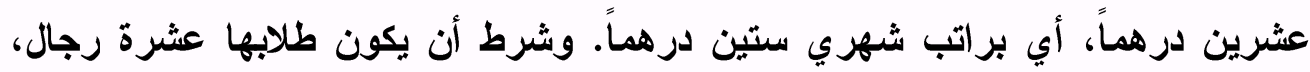

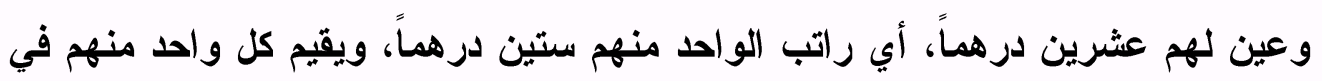

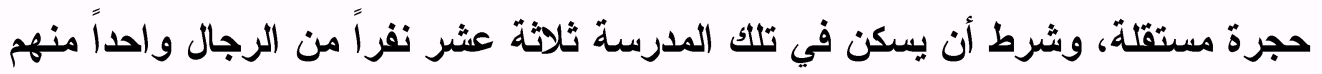

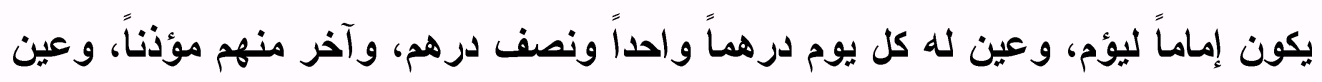

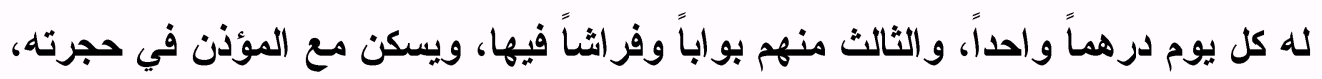

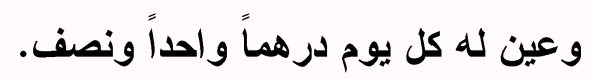

وعين لأثمان حصير والفراشه والدهن كل يوم درهماً واحداً، وعين الواقف ونف

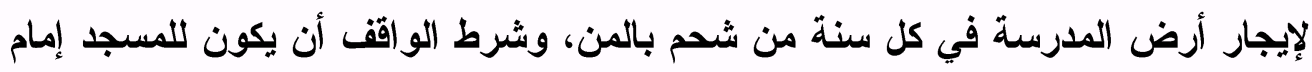

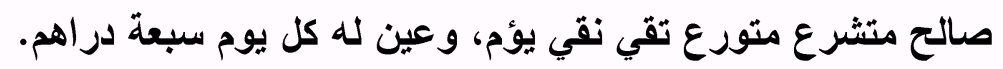

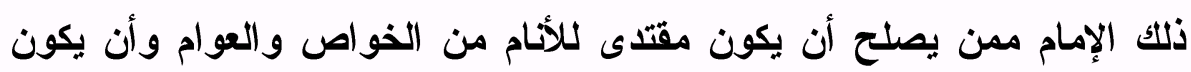
للمسجد مؤذن صالح موصوف بحسن الصوت، وعين لله كل يوم خمسة دراهم، ويكون لاهن

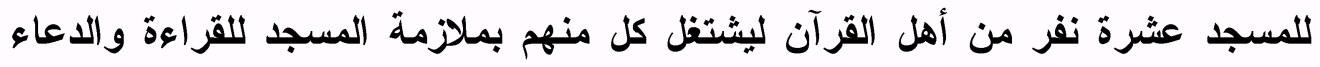

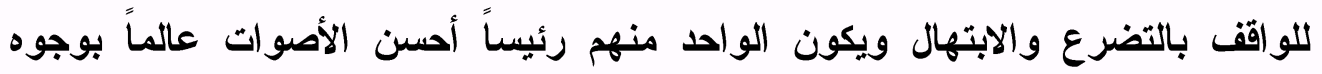
القراعات، وعين لرئيسهم المعروف بسر محفل كل يوم درهمين.

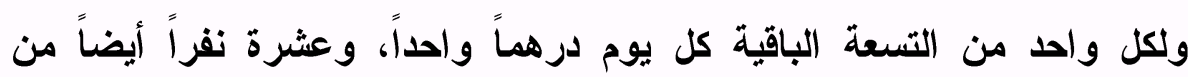

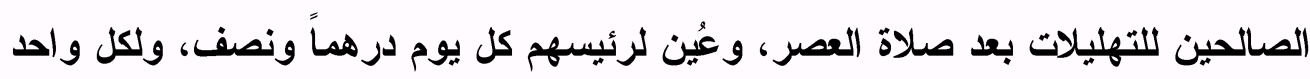

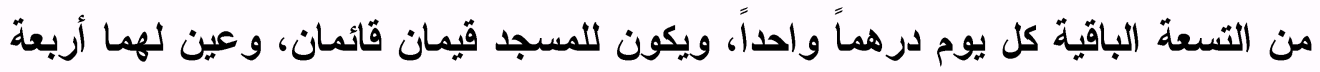

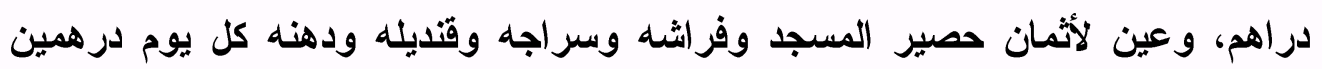
وعين لمن يأتي بالماء لسقاية المسجد كل يومٍ درهماً. وشرط الواقف أن يكون للمكتب المذكور معلم منشرع متورع تقي نقي قادر علي

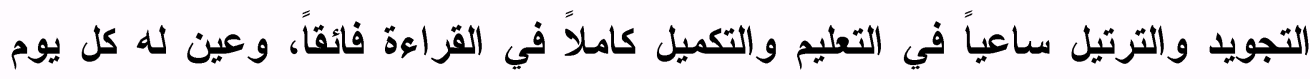

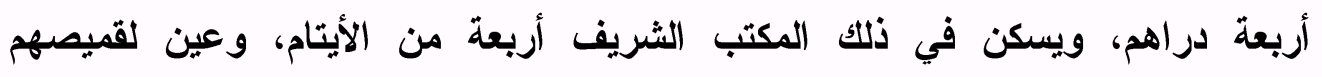


وكسوتهم وقلنسوتهم ومداسهم، وأثار إلي إثراف من يكون من القضاة في وقته علي

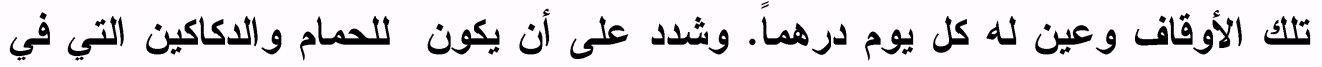
التوقات مرمم، وحدد الأشتراطات الواجبة فيه، وعين له كل يوم ثلاثة دراهم. وشرط

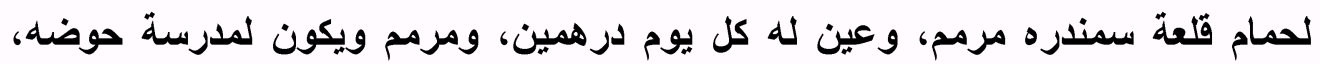

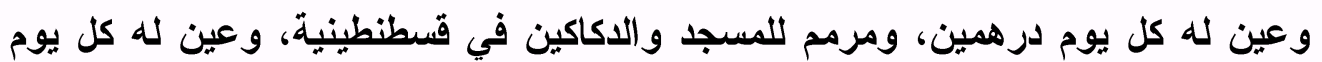

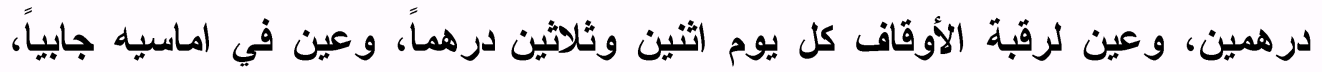
وعين له كل يوم خمسة دراهم. ويكون للبستاني في قرية أغاثيوس ناحية قسطنطينية، وعين لله كل يوم درهمين.

وإن فضل من رزق المرتزقة شئ بفضل الله يحفظ جميعه لرقبة المدرسة

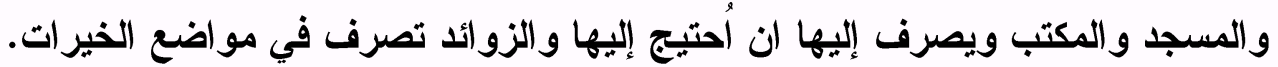
وحذر بأن لا يعطى لأحد كائناً من كان شئ من زوائد الأوقاف، وأوضح طرئ فيقة

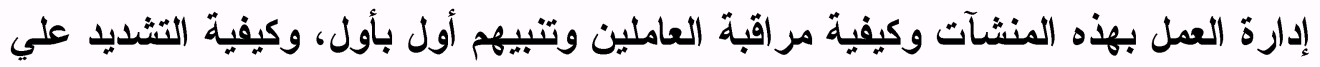
العقوبات. ومدى مراعاة الأبعاد الإنسانية في العوز والحاجة والكفالة. ثم الحديث عن لهن متولي الوقف وذكر العظة في هذا الثأن. وذكر اسماء القضاة وألقابهر مع ملاحظات تكرار اسمائهم والجمل والعبارات المؤدية لذلتك. ثم الحديث عن الشهود وهم: مولانا أحمد بن قرجه، والحاج نصوح بن عبدالله، و الحاج مصطفي بن عبدالله، ثم ذكر أن الوقف المشار إليه وقفاً لازماً مسجلاً متفقاً عليه حاوياً لجميع المصححات وشروط الانعقاد خاوياً عن المبطلات وموجبات الفساد مؤكداً

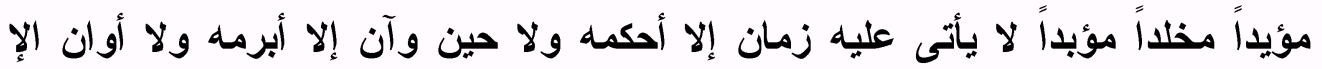

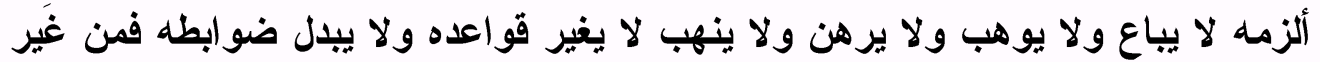

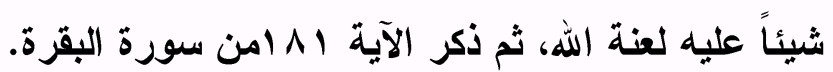

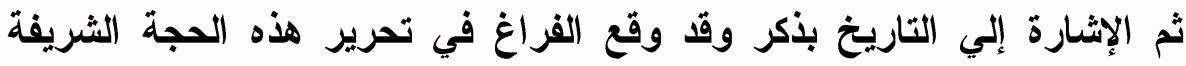

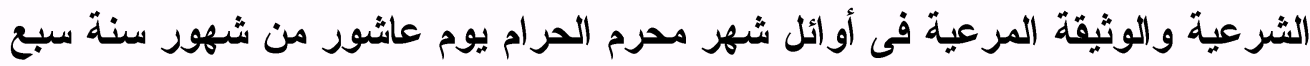
وتسعين وثمانمائة، ثم اسماء شهود الحكم والتسجيل السالفين الذكر، ثم ذئمر أثر تأشيرة و إقرار القاضي عبدالرحمن بن علي بن المؤيد، ثم ألقاب الواقف العديدة ومنها إفتخار

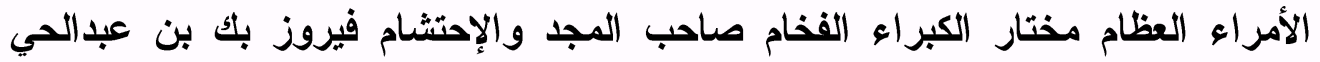

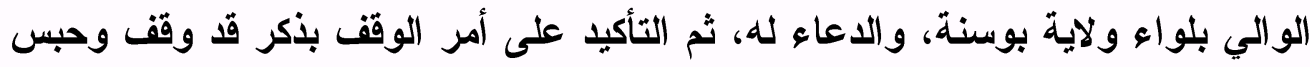


وأبد وسبل بنية صافية وطوبة خالصة راجياً من الله تعالي جزيل ثوابه، والإشارة إلي بعض من العقار انت الأخرى الكائنة في قسطنطينية، وذكر حدودها وأبعادها، وكذا الإثارة إلي العقارات الكائنة في مدينة أدرنة مي ذكر تفاصيلها

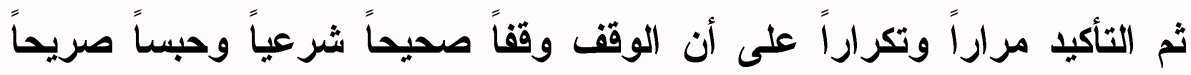

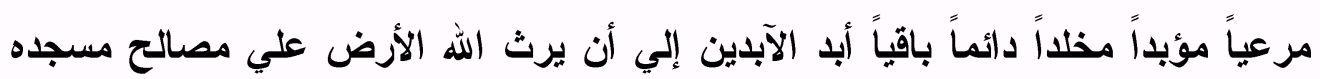
ومكتبه ومدرسته بقسطنطينية.

وشرط أن يكون جباية أوقافه كلها للأصلح من عتقائه ثم للأصلح من أولاد

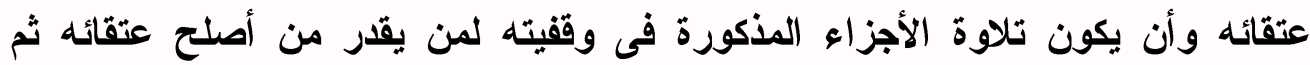

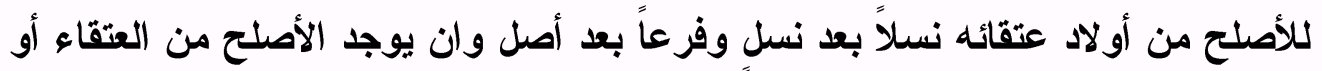

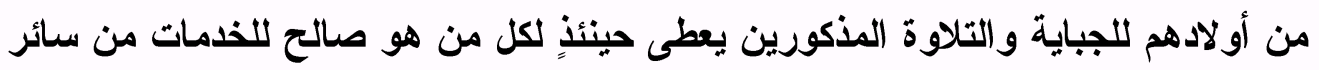

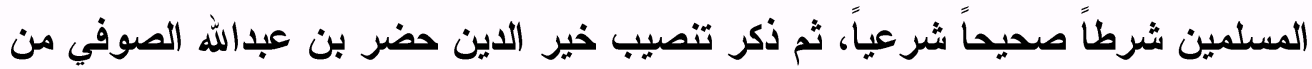
جملة خدام الواقف متولياً للأوقاف الثابت توليته عليها بثهادة مولانا على بن ابراهيم

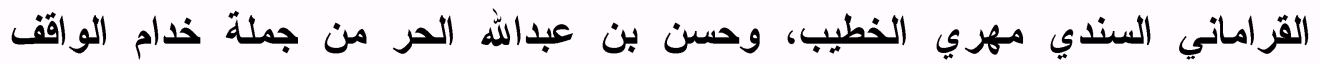

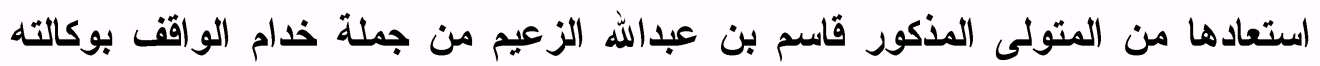
بالرجوع عن وقفية الأوقاف المذكورة عن قبل الواقف المزبور بعد ما ثبت وكالته عند

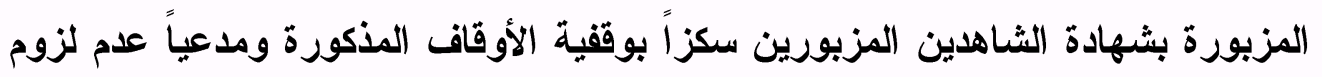
الوقف وصحة الرجوع عنه بتقدير ثبوت وقفيتها فتر افعا إلى المولي الحاكم الموقع أعلاه

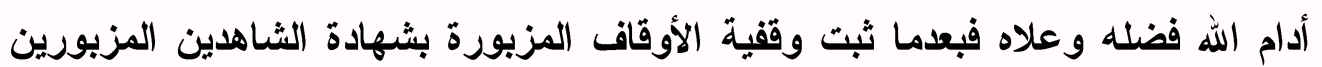
عقيب الإشهاد الثرعي وأثر الدعوة الصحيحة الصادرة عن متولى المذكور بمحضر من ونه الوكيل قاسم المزبور بأن وقف فيروز بك المذكور صاحب الأوقاف المذكورة

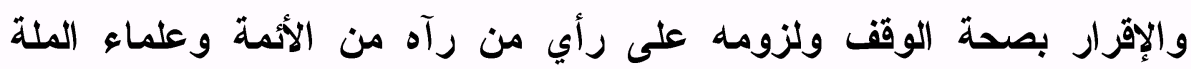

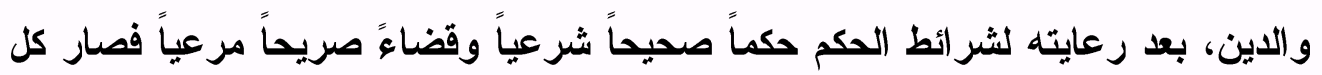

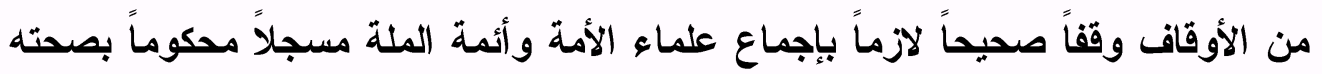

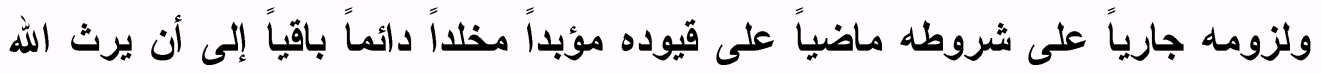

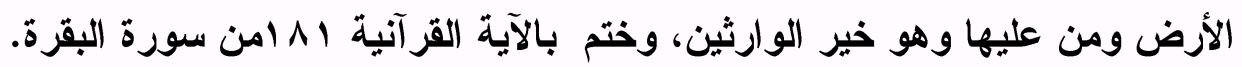




\section{نتائج الدر اسة}

نشر وتحقيق ودراسة نسخة طبق الأصل من وثيقة عثماتية، للوقوف على شكلها

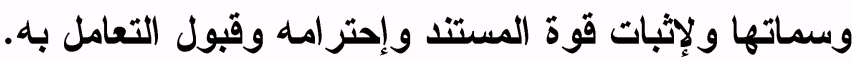
بينت الاراسة أن حجة فيروز أغا، من أكثر حجج الأوقاف التي شملت العديد من بن بنه

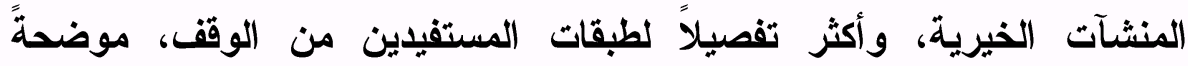

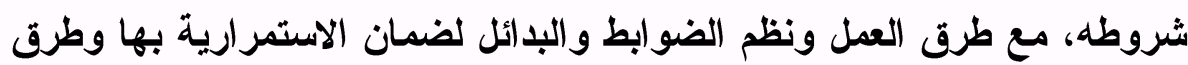
المحاسبة، بشكل حضاري أبلاع ما يكون. بينت الاراسة أن النصوص الكتابية في وثائق الوقف العثمانية العية، اتسمت بالإعتدال والفصاحة في الأسلوب، وإعتراها الضعف والركاكة في الصياغة أحياناً، لإستخدام اللهجة العامية في كثير من الأحايين.

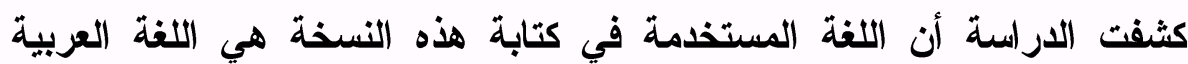
وليست التركية، لإضفاء صفة الثرعية عليها عند التعامل بها.

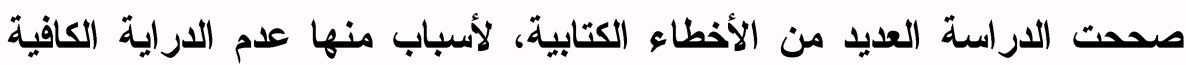

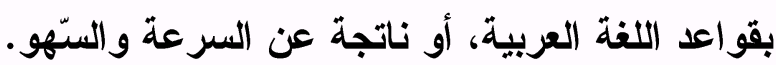
صححت الاراسة العديد من الأخطاء التي أرتكبها الخطاط، في الآيات القرآئة، والأحاديث النبوية، وكذا الخطأ في كتابة أسماء القرى والبلان، وأخطاء النحو النواء النات والصرف. أثشارت الاراسة إلي ظاهرة قلب الألف إلى ياء، وإهمال حرف الألف الوسطى،

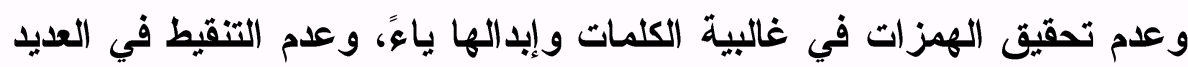
من الكلمات.

لاحظت الاراسة أن لغة كاتب الوثيقة بغض النظر عن الرسم الإملائي المعتاد في تلك العصور، لغة أدبية محكمة، تنوعت ما بين الجمل الطويلة والقصيرة، وما لإنها فيها من تراص وتوازٍ، ارتفع إيقاعها بما حشده الكاتب من أنساق البديع العربي

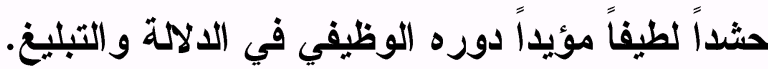
لاحظت الدراسة وجود فراغ واضح بين السطور، وجميعها متواز أفقي مستقيم،

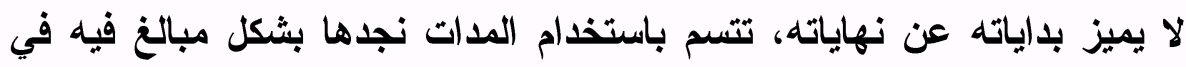
حروف السبن و الكاف و التاء. 
حوت الوثيقة على العديد من أسماء الأماكن والبلان، من القرى والقضاءات

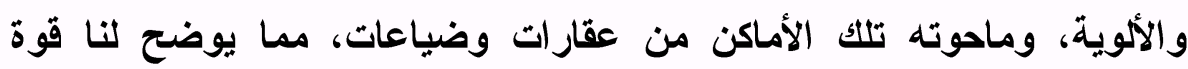
شخصية الو اقف وهيمنته المالية في عصره.

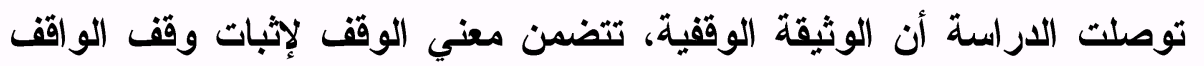

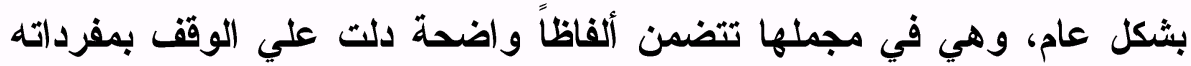
المتنوعة، في مجملها صورة من كتابات العصر العثماني في صياغة قو البها.

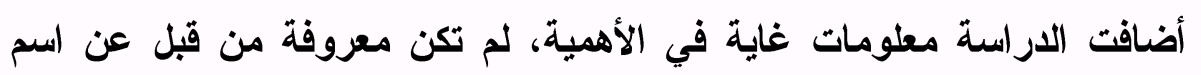

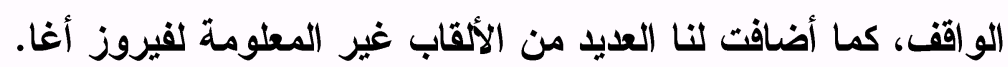

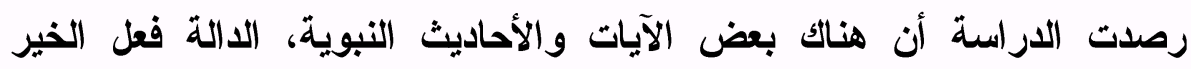
والتذكير بأن الآخرة هي دار القرار، وكذا تحريم التبديل أو التغيير في الأوقاف، التهات التي تكرر استخدامها في مضامين الوثائق الوقفية. حصرث الاراسة العديد من الألفاظ والمصطلحات المتعلقة بالوقف وأنف ألفاظه

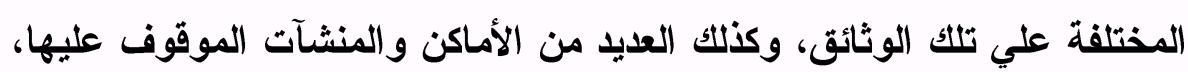
وفئات من شملهم الوقف. نشرت الاراسة لأول مرة مجموعة كبيرة من الألقاب والوظائف للواقف،

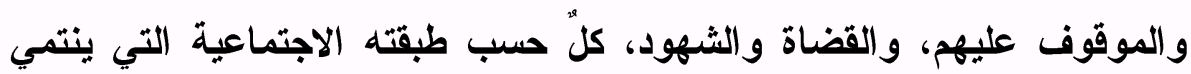




\section{قائمة المصادر والمراجع}

القر آن الكريم.

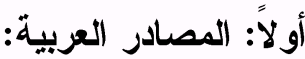

البزازي (محمد بن محمد بن شهاب الكردي البريقيني ت ت \هــ): الفتاوى البزازية أو الجامع الوجيز في

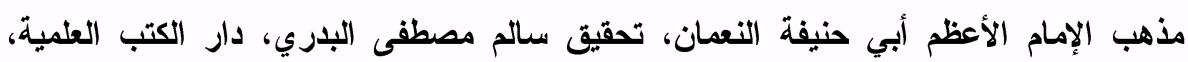

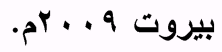

البهوتي (منصور بن يونس بن إدريس ت اهـ ـ اهــ): كثاف القتاع عن متن الإقتاع، راجعه وعلق عليه

$$
\text { هلال مصيلحي مصطفي هلال، دار الفكر، بيروت ب } 9 \text { ام ام. }
$$

الثعالبي (عبدالملك بن محمد بن إسماعيل أبومنصور ت هو؟ـهـ): اللطائف والظرائف، دار المناهل،

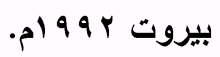

حاجي خليفة ت V7 ـ اهـ: كثف الظنون عن اسامي الكتب والفنون، دار إحياء التراث العربي، بيروت

$$
\text { د. }
$$

ياقوت الحموي (ثهاب الدين أبى عبدالله الرومي البغدادي تجr جهــ): معجم البلدان، دار صادر، بيروت

$$
\text { . ) } 9 \vee V
$$

الحنبلي (عبدالحي بن أحمد بن محمد ابن العماد ت1 ه ـ 1هـ): شذرات الذهب في أخبار من ذهب، تحقيق

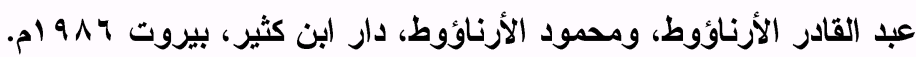

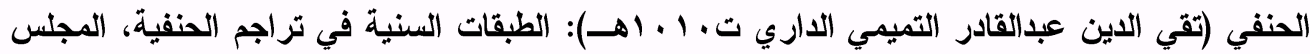

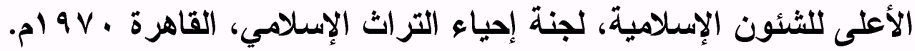

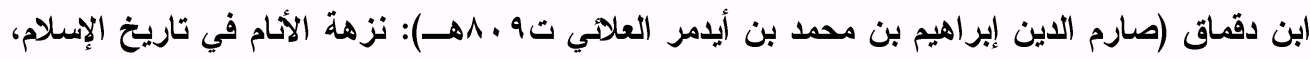

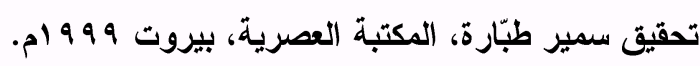

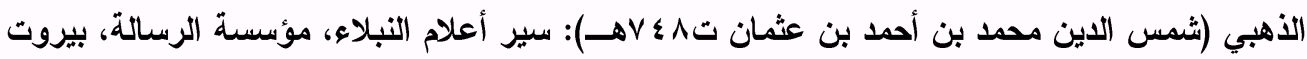

$$
\text { . . . } 1
$$

السمرقندي (أبي الليث نصر بن محمد بن إبراهيم ت ه هrهـ): فتاوى النوازل، تحقيق السيا يوسف

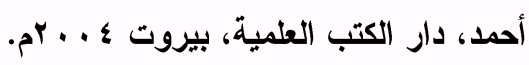

ابن سيده (علي بن إسماعيل أبوالحسن تمهـهـ): المخصص، المطابع الأميرية ببولاق، القاهرة strr.

الثيباني (أبو عبدالله أحمد بن محمد بن حنبل بن هلال بن أسد ت اء هــ): مسند الإمام أحمد بن حنبل،

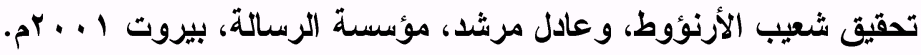

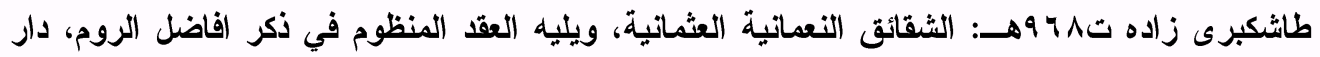

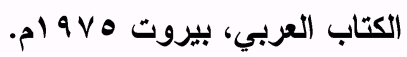


أبوالطيب (عبدالواحد بن علي اللفوي الحلبي تاهـهـ): الإبدال، تحقيق عزالدين التنوخي، مجمع اللغة

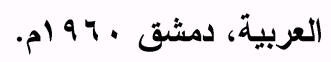

ابن عساكر (أبي القاسم علي بن الحسن بن هبةالله الثافعي ت الVهــ): تاريخ مدينة دمشت وذكر

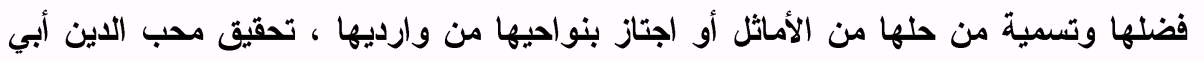

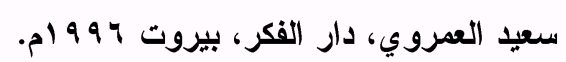

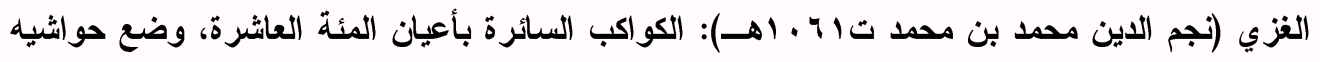

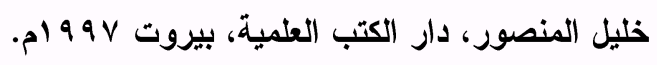

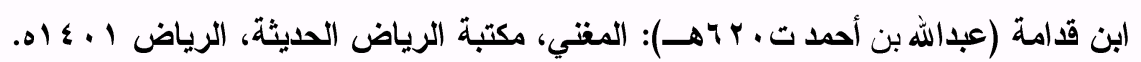

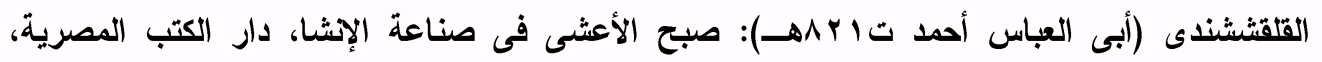

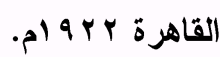

المقري الفيومي (أحمد بن محمد بن علي ت. •VDــ): المصباح المنير في غريب الثرح الكبير للرافعي،

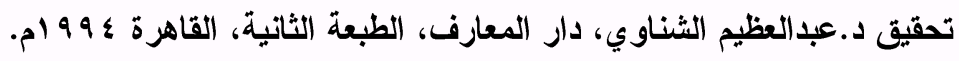

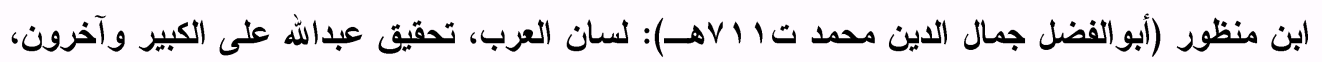

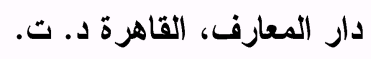

ثانياً: المراجع العربية الحديثة: إبراهيم حليم: تاريخ الدولة العثمانية العلية المعروف بالتحفة الحليمية في تاريخ الدولة العثمانية، مؤسسة

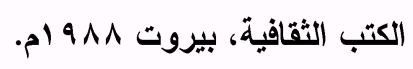

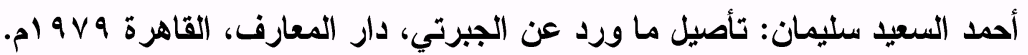
أحمد خلف السبعاوي: المشيدات الوقفية والعمرانية في مصر خلال العصر المملوكي دراسة المئ تاريخية،

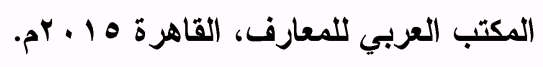

أميرة بنت علي مداح: أوقاف النساء في مكة المكرمة في العصر العثماني ودور المرأة فيها، دار القاهرة،

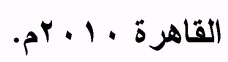

أمين مدني: الثقافة الإسلامية وحواضرها، الهيئة المصرية العامة للكتاب، القاهرة . ـ 9 ام.

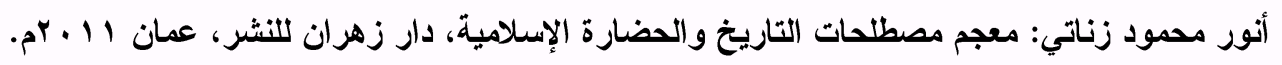

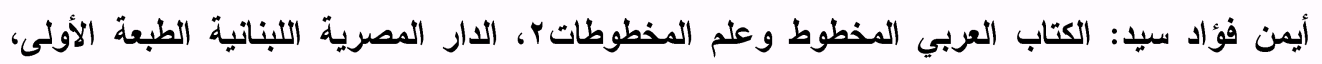

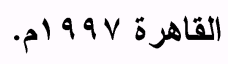

الوصف المادي للمخطوطات، ضمن ندوة قضايا المخطوطات سبتمبر 991 ام، ونشر في فهرسة المخطوطات مدخل وقضايا، تنسيق وتحرير د. فيصل الحفيان، معهد المخطوطات

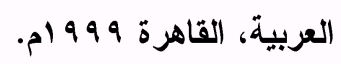

أبو حامد محمد بن محمد الغزالي: إحياء علوم الدين، دار المعرفة، بيروت 9 ام ام. 
حسن حلاق، عباس ضباع: المعجم الجامع في المصطلحات الأيوبية والمملوكية والعثمانية ذات الأصول

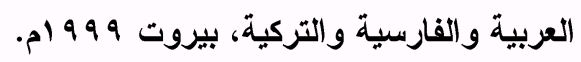

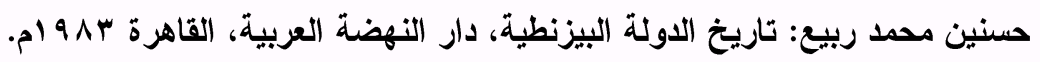
خيرالدين الزركلي: الأعلام قاموس تراجم لأثهر الرجال والنساء من العرب والمستعربين والمستثرقين،

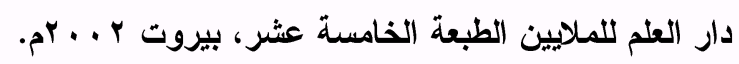

سمير يحيى الجمال: تاريخ الموسيقى المصرية وتطورها، الهيئة المصرية العامة للكتاب، القاهرة، . 1999

سهيل صابان: المعجم الموسوعي للمصطلحات العثمانية التاريخية، مكتبة الملك فهر الوطنية، الرياض

$$
\text { . }
$$

$$
\text { سيد محمد السيد محمود: تاريخ الدولة العثمانية، مكتبة الآداب، القاهرة V . . rم. }
$$

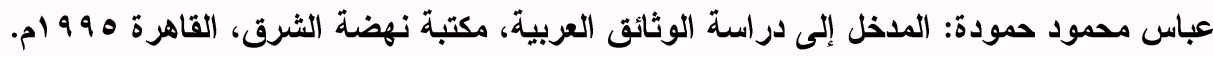
عبداللطيف محمد الحميد:تاريخ الأوقاف في المملكة وسبل تطويرها، بحث في ندوة مكانة الوقف وأثره في

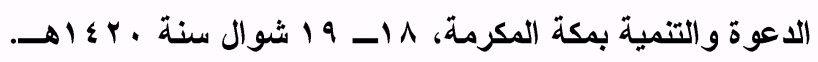

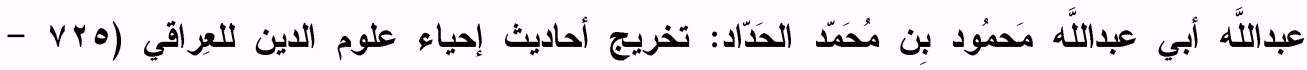

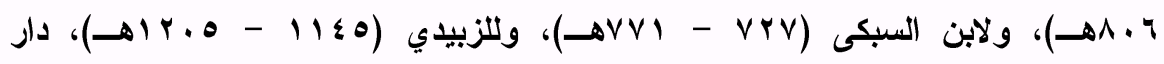

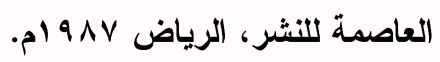

عبدالحكيم العفيفي: موسوعة . . . 1 مدينة إسلامية، أوراق شرقية للنشر والطباعة، بيروت، ـ . . . بم.

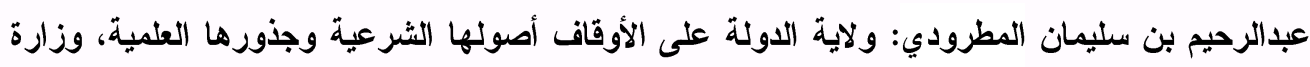

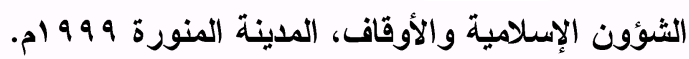

عبدالعزيز بن محمد الحجيلان: الولاية على الوقف وأثرها في المحافظة عليه، بحث مجلة جامعة الإمام

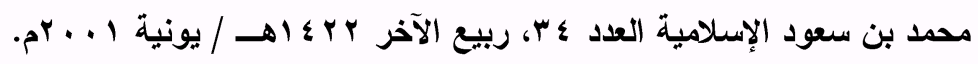

عبداله الدروبي: ايجابيات التعاون بين دول حوضي نهري دجلة والفرات لاستغلال مواردهما المائية

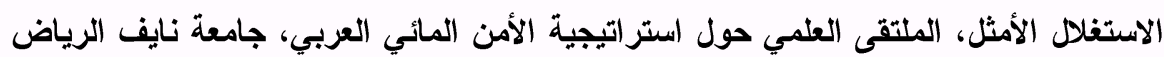

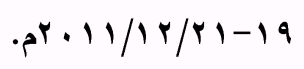

عزتلو يوسف بك آصاف: تاريخ سلاطين بنى عثمان، كلمات عربية للترجمة، القاهرة ب ب أ. Y. عصام عبدالرؤوف: الدول المستقلة في المشرق الإسلامي منذ مستهل العصر العباسي حتى الغزو

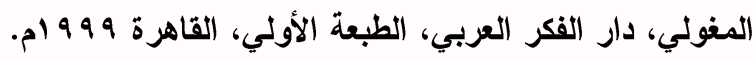

عفيف البهنسي: معجم مصطلحات الخط، بيروت 99 ام. 9 ام. على محمد محمد الصلابي: الدولة العثمانية عوامل النهوض وأسباب السقوط، دار الفجر للتراث، القاهرة . . . .

عمر رضا كحالة: معجم المؤلفين، مكتبة المثي دار إحياء التراث العربي، بيروت د.ت. 
العياثي الصادق فداد: الوقف مفهومه شروطه أنواعه، بحث بمؤتمر الأوقاف الأول جامعة أم القرى

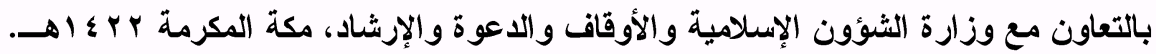

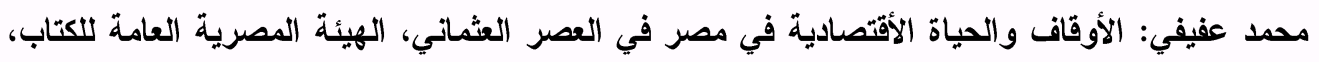

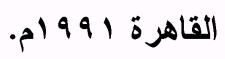

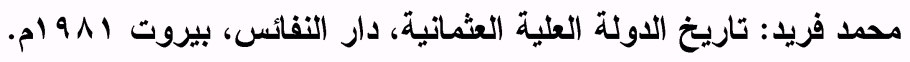

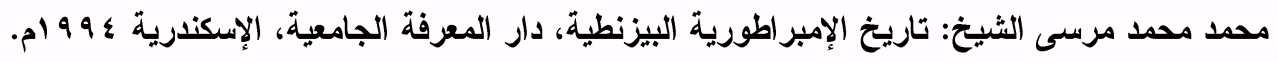

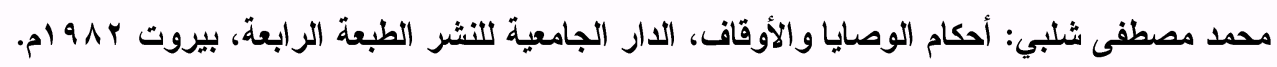

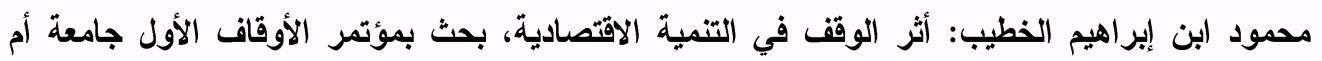

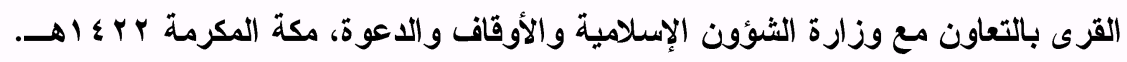
مصطفى بركات: الألقاب والوظائف العثمانية دراسة في تطور الألقاب والوظائف منذ الفتح العثماني والثاني

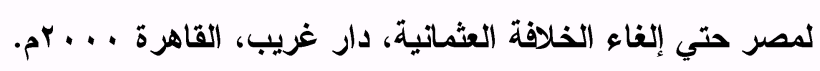

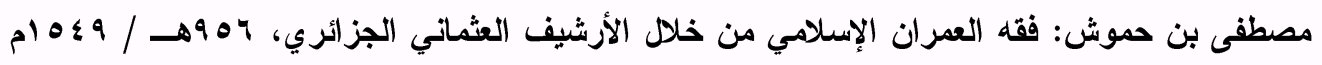

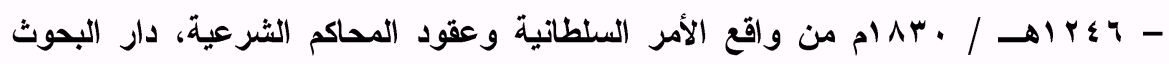

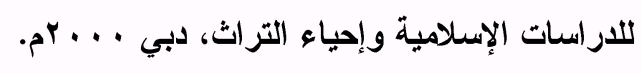

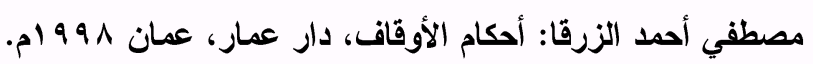

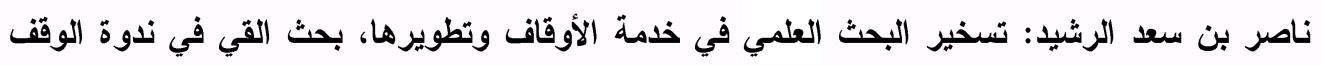

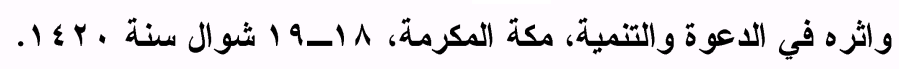

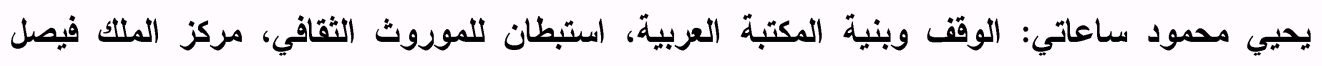

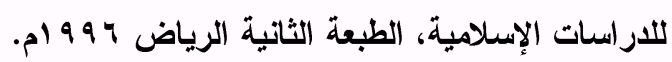

ثالثاً المراجع التركية:

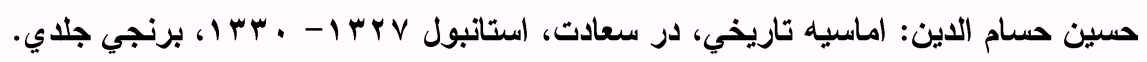

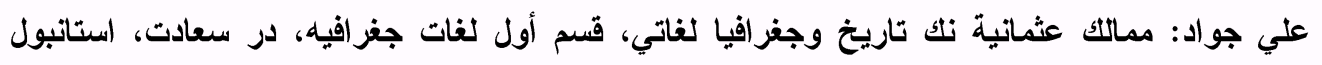
(T)

رابعاً: المراجع الأجنبية المترجمة: أكمل الدين إحسان أوغلى وآخرون: الدولة العثمانية تاريخ وحضارة، نقله للعربية صالح سعداوي، مركز البحوث للتاريخ والفنون و الثقافة الإسلامية، استانبول 99 و 9 ام.

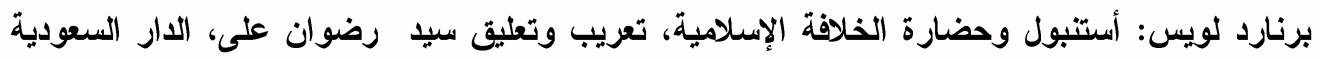

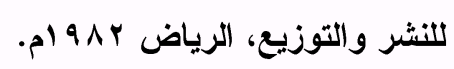

فيوتو: وصف مصر "الموسيقى والغناء عند المصريين المدثثين، ترجمة زهير الثايب، مكبة الحانجى،

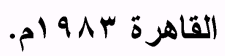


كي لسترنج: بلان الخلافة، ترجمة بشير فرنسيس وكوركيس عواد، بلدان الخلافة الثرقية، نقله للعربية

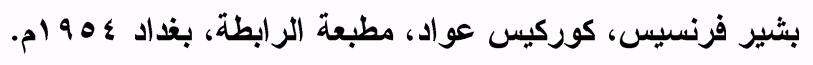

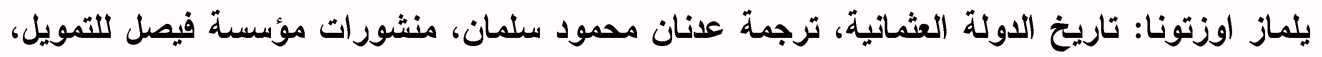

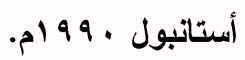

خامساً: الدوريات:

عبدالعزيز بن محمد الحجيلان: الولاية على الوقف وأثرها في المحافظة عليه، بحث مجلة جامعة الإمام

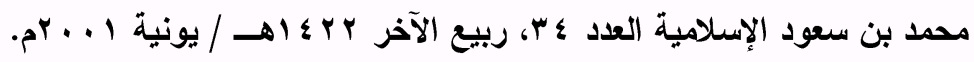

عبدالمنصف سالم حسن: شعار العثمانيين على العمائر والفنون في القرنين الثاني عثر والثالث عثر الثر الثرن

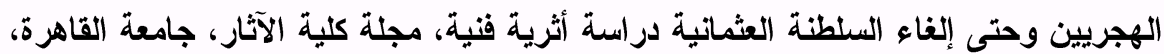

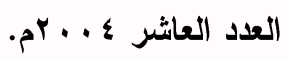

محمد عبد الستار عثمان: مصحف بالقراعات السبع بجزيرة شندويل، مجلة العصور، دار المريخ للنشر،

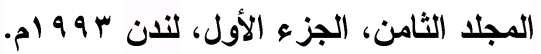

محمد عبد العزيز مرزوق: المصحف الثريف دراسة تاريخية فنية، مجلة المعهد العلمي العراقي، بغداد p) $9 \mathrm{~V}$.

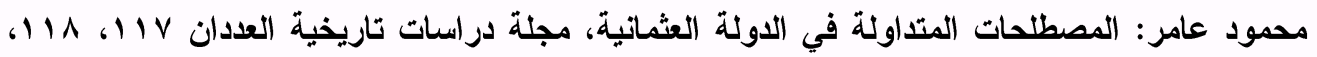

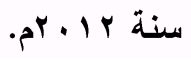

نصار محمد منصور وآخرون: خط النستعليق الجذور التاريخية والخصائص الفتية، بحث بالمجلة الأردنية

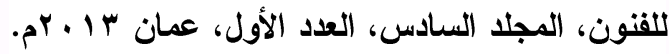

سادساً: الرسائل العلمية:

حسن محمد نور: صور المعارك الحربية في المخطوطات العثمانية، مخطوط رسالة ماجستير، كلية الآثار

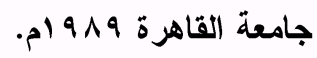

سمية حسن محمد إبراهيم: صور الإحتفالات في المخطوطات العثمانية دراسة أثرية فنية، مخطوط رسالة

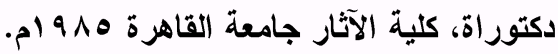

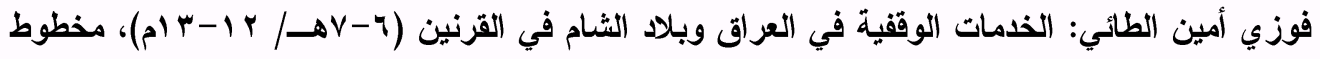

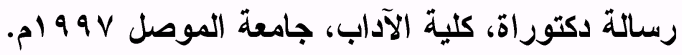

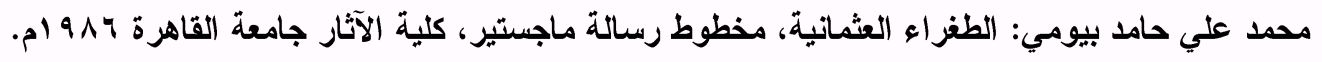
منى السيد عثمان مرعي: رسوم عمائر مدينة إستانبول من خلال تصاوير المخطوطات العثمانية، مخطوط

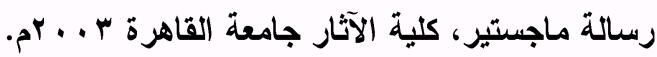




$$
\text { سابعاً: المراجع الأجنبية: انية }
$$

ABD.SSEIIM ULUIAM: KLASiK DÖNEM OSMANLI MiMARiSi, in Osmanlı, Kültür Ve Sanat, Yeni Türkiye Yayınları, Cilt:10, Ankara 1999.

Abdülkadir Özcan: HOŞKADEM, islam ansiklopedisi, cilt.18, Ankara 1998.

Ali Açkel: TOKAT, Ali Açıkel, islam ansiklopedisi, cilt. 41, Ankara,.

Evgeni RadusheV, Svetlana IVanova, Rumen KoVachev: INVENTORY of Ottoman Turkish Documents about Waqf Preserved in the Oriental Department at the St St Cyril and Methodius National Library, Vol.1, Sofia 2003.

Huri Islamoglu-Inan: State and Peasant in the Ottoman Empire, Agrarian Power Relations and Regional Economic Development in Ottoman Anatolia During the Sixteenth Century, E.J. Brill, New York 1994.

İLHAN ŞAHIN - FERIDUN EMECEN: AMASYA Karadeniz bölgesinin iç kesiminde Şehir ziyaretinde bu Şehrin merkez Olduğu il. İslam Ansiklopedisi, cilt 3, Ankara 1991.

Medhat Sertoglu: Osmanlı Tarih Lügatı, Istanbul 1986.

Mehmet Canatar: 1009/1600 Tarihli istanbul Vakıfları Tahrir Defteri'ne Gore Nefs-i istanbul'da Bulunan Mahalleler ve Ozelliklerine Dair Gozlemler.

MEHMET GENÇ: MALİKANE, islam ansiklopedisi, cilt. 27, ankara 2003.

MEHMET GENÇ: MALiKANE-DiVANi, islam ansiklopedisi, cilt. 27, ankara 2003.

Revista Istorica: Dari De Sama, Documente si notite sup Conducerea lui. Iogra, Anulal 23-le 7-9 Julie- September 1937.

ÜMER DEMiREL:SiVAS, islam ansiklopedisi, cilt.37, Ankara 2009.

YusuF KüçüKDAG: PIRi MEHMED PAŞA, Ramazanoğlu, islam ansiklopedisi, , cilt. 34, Ankara 2007. 
كتالوج الأثكال و اللوحات

\begin{tabular}{|c|c|c|c|}
\hline كنتهية & متوسظة & مبتّأه & صور الحرف \\
\hline 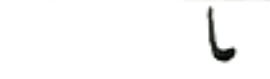 & - & 1 & \\
\hline 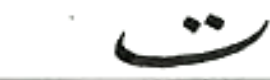 & ل & $\sim . \%$ & ب-ت ب-ت \\
\hline 10 & 5 & s'ת & $\dot{\tau}-\tau-\tau$ \\
\hline 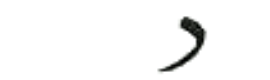 & $\mathcal{L}$ & 9 & دئ \\
\hline & - & 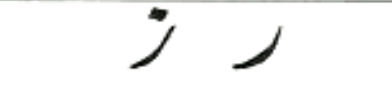 & j-j \\
\hline & ممر مُه & $\sim$ & س- ش ش \\
\hline & صهر & $\infty$ & ص- ض \\
\hline & b & b & طـ \\
\hline & $x$ & S & $\dot{\varepsilon}-\varepsilon$ \\
\hline & ه & 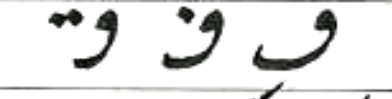 & ف- ق \\
\hline & - & & s \\
\hline & s & $\rightarrow 1$ & ? \\
\hline$\dot{~} \bullet$ & i & e & $\dot{ن}$ \\
\hline$N \sim$ & $\mathcal{N}$ & $\infty 0$ & $ه$ \\
\hline 9 & - & 9 & $s$ \\
\hline I) & - & I) U & $\mathrm{Y}$ \\
\hline $5 \circlearrowleft$ & $\overbrace{\infty}^{2} \overbrace{\infty}$ & r. & $s$ \\
\hline
\end{tabular}

(شكل () التحليل الأبجدي لحروف كلمات النسخة الأصل لوثيقة وقف فيروز أغا 
وثيقة وقف شرعية عثمانية دراسة أثرية حضارية

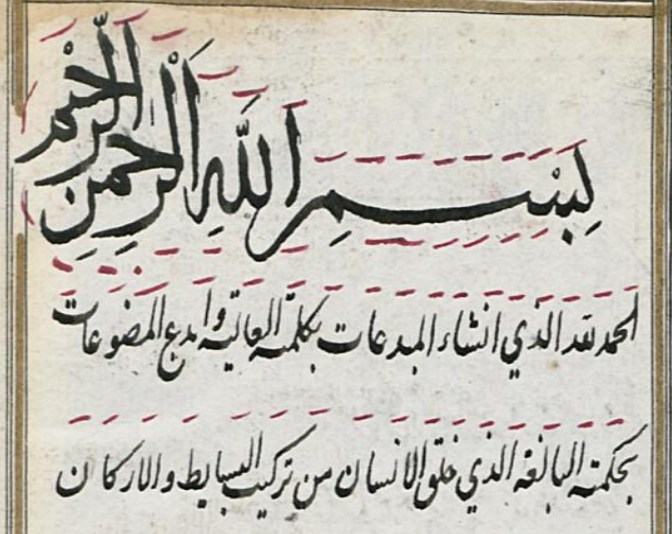

s 4.

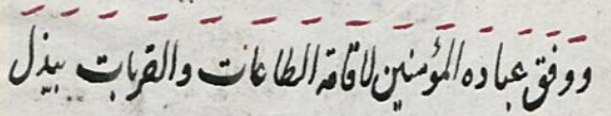

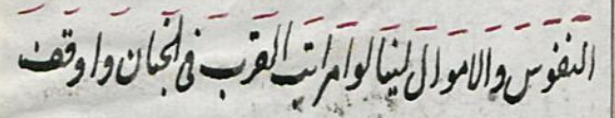

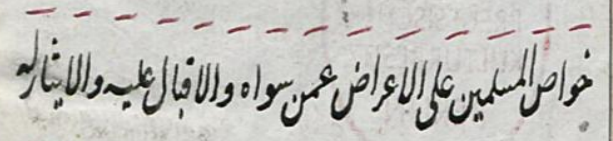

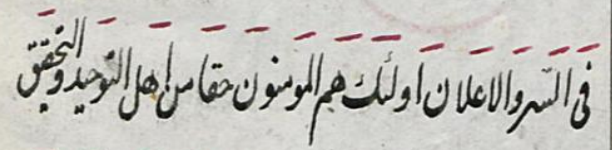
1) , (W)

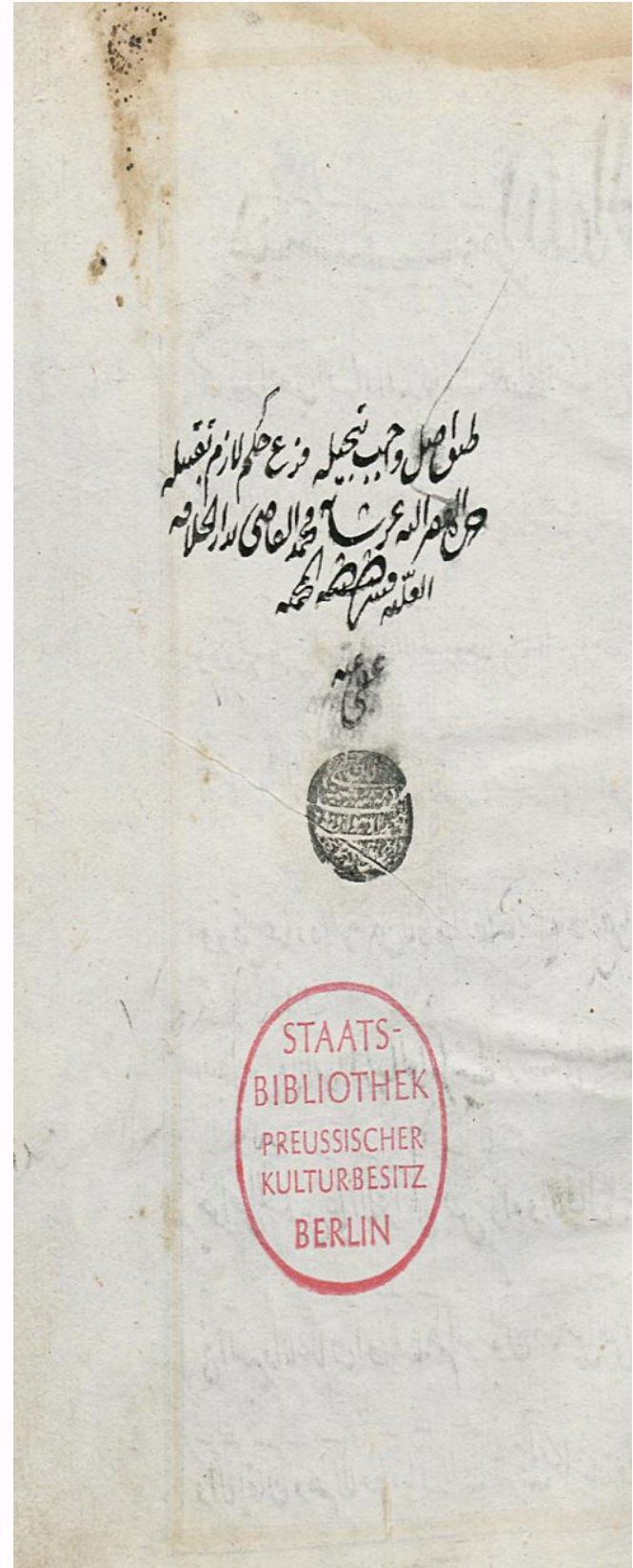

(لوحة ا ) وجه الورقة الأولى و عليه تأثيرة القاضي بجواز العمل بهذه النسخة طبق الأصل الطيل

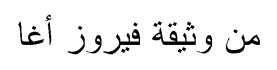




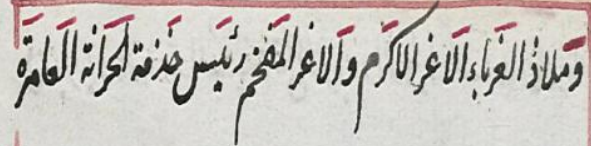

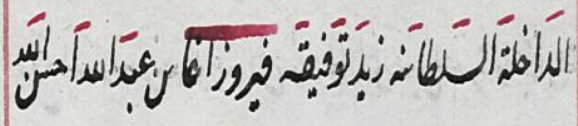

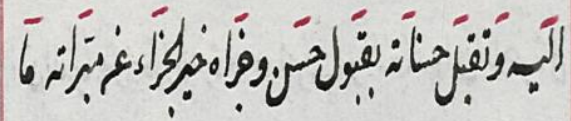

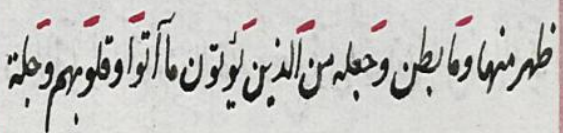

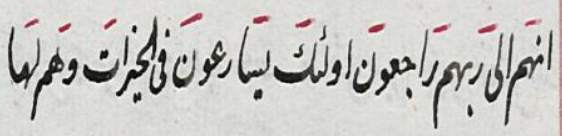

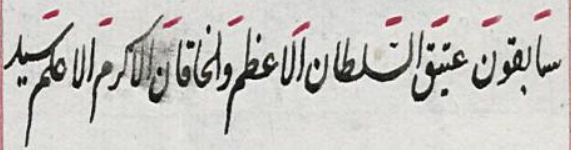

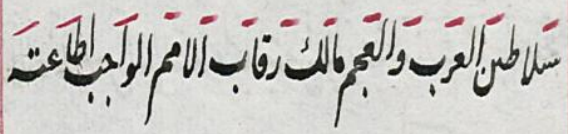

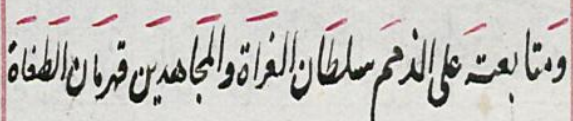
淄

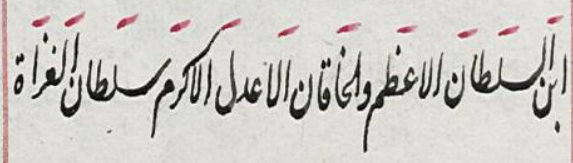
")

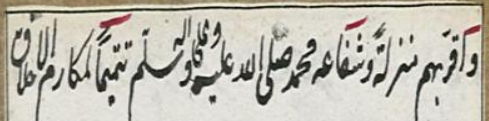

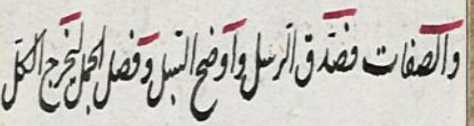
"is.

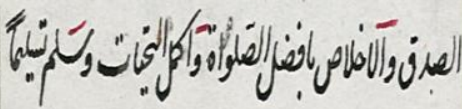

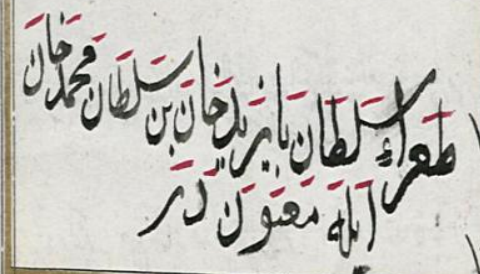

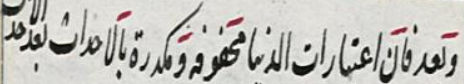

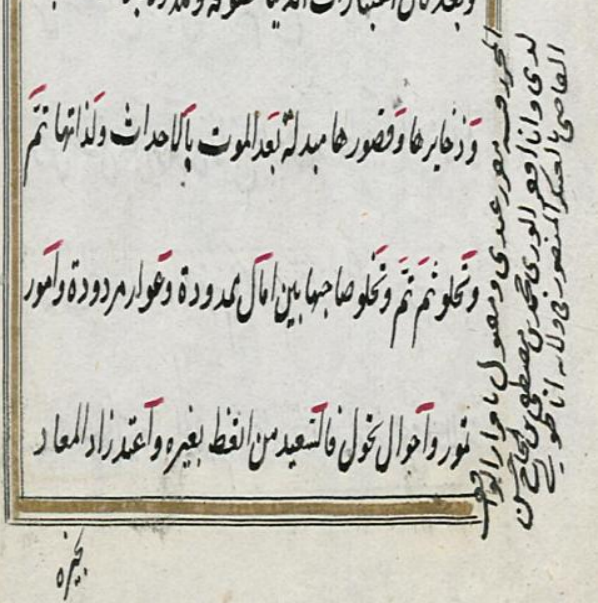

(لوحة") ظهر الورقة الثانيه ويوضح الإثارة إلي مكان الطغر اء وتو اقيع وتأثير ات القضاة 
وثيقة وقف شرعية عثمانية دراسة أثرية حضارية

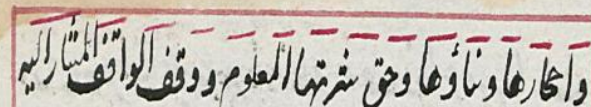
家

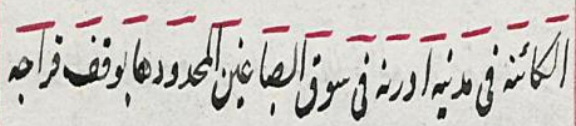

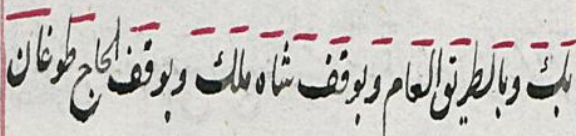

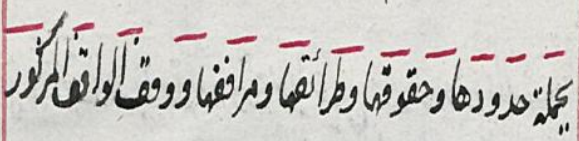

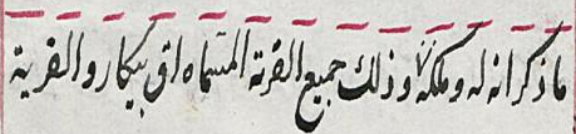

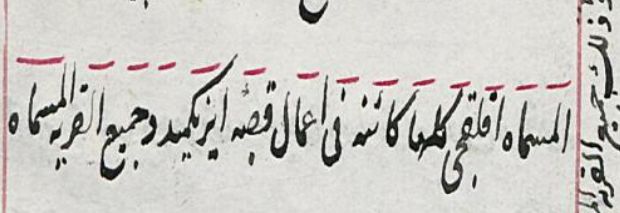

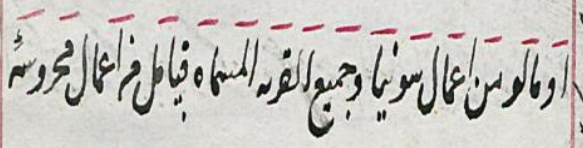

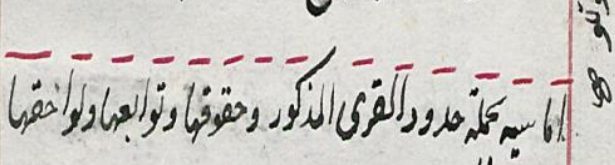

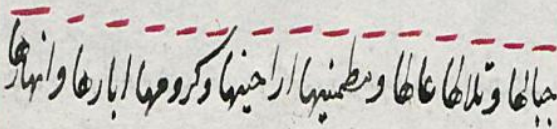
نَ (لوحة") ظهر الورقة الواحده والعشرين وتوضح سهو الخطاط و إستدر اكه 


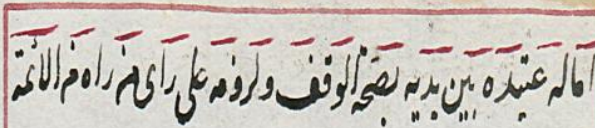

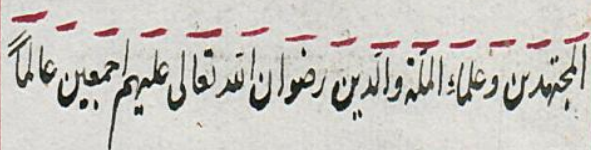

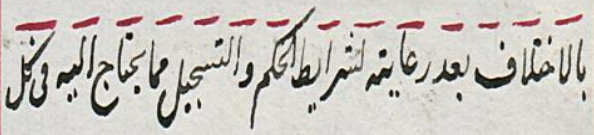

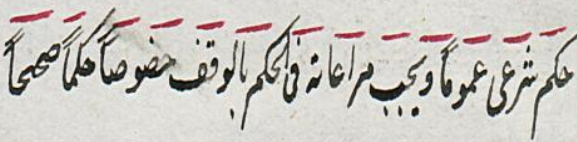
بر :

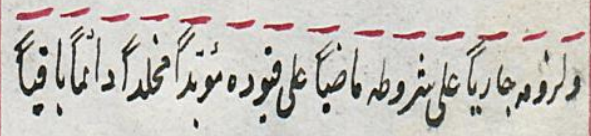

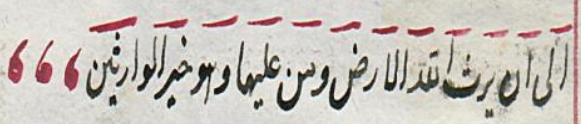

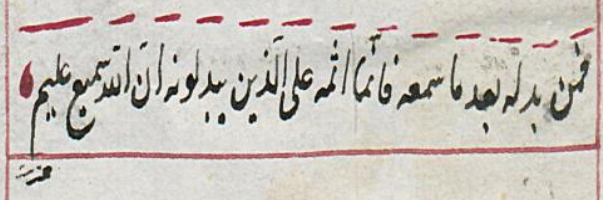
(لوحة ^) وجه الورقة الر ابعه و العشرين من النشخة وهي تمثل الصفحة الأخيرة منها.
نे

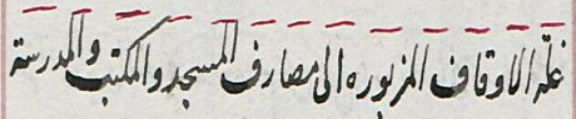

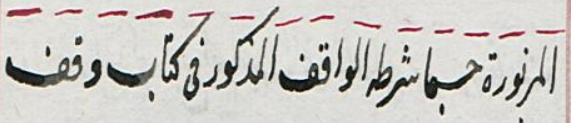

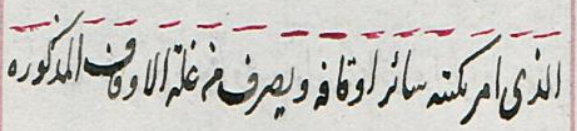

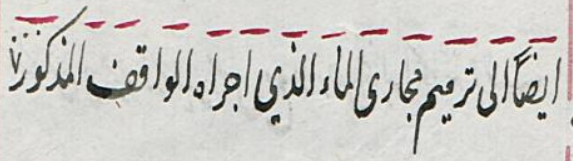

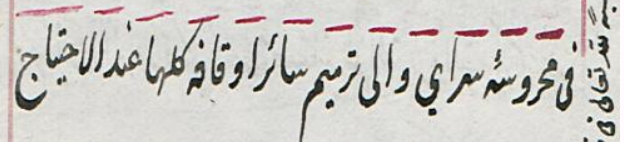
- - - - - - - - - - - - i

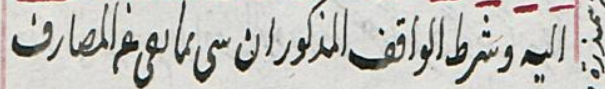

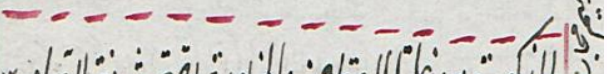

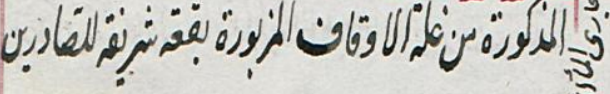
- - - - - - - - - - - - -

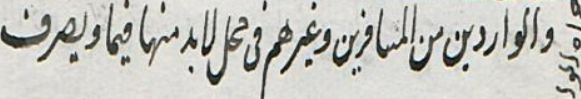

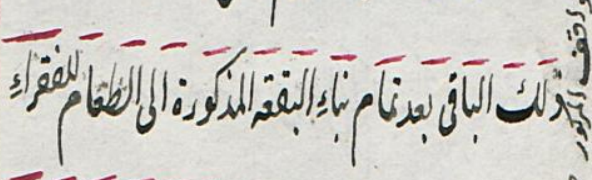

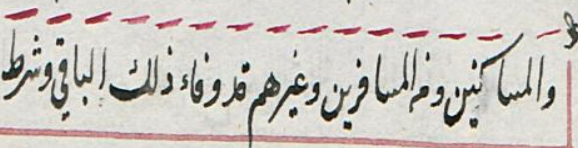

(i)

(لوحة (V) ظهر الورقة الثانيه و العشرين وتوضح سهو الخطاط و استثر اكه علي يمين الصفحة 